\title{
ENLEIRAMENTO E ENFARDAMENTO CILÍNDRICO DE PALHIÇO DE CANA-DE-AÇÚCAR: ALGUNS PARÂMETROS DE DESEMPENHO OPERACIONAL E EFICIÊNCIA ENERGÉTICA
}

\author{
SÉRGIO FABRÍCIO GONÇALVES BIZUTI \\ Engenheiro Mecânico
}

Orientador: Prof. Dr. TOMAZ CAETANO CANNAVAM RIPOLI

\begin{abstract}
Dissertação apresentada à Escola Superior de Agricultura"Luiz de Queiroz",Universidade de São Paulo, para obtenção do título de Mestre em Agronomia, Área de concentração: Máquinas Agrícolas.
\end{abstract}

P I R A C I C A B A

Estado de São Paulo - Brasil

Outubro - 2003 
Sérgio Fabrício Gonçalves Biżuti. Enleiramento e enfardamento de palhiço de cana-deaçúcar: Alguns parâmetros de desempenho operacional e eficiência energética

$\begin{array}{lllll}\text { p. } & \text { item } & \text { linha } & \text { onde se lê } & \text { leia-se } \\ \text { xv } & \text { Resumo } & 7 & 22^{\circ} 40^{\prime \prime} 3^{\prime} & 22^{\circ} 40^{\prime} 30^{\prime \prime} \\ \text { xv } & \text { Resumo } & 7 & 47^{\circ} 36^{\prime \prime} 33^{\prime} & 47^{\circ} 36^{\prime} 38^{\prime \prime} \\ 21 & 3.1 .3 & 1 & \text { Fontes } & \text { Foram } \\ 41 & 4.2 & 11 & 18 & 17 \\ 66 & \text { Quadro 10 } & 1 & \text { MPS } & \text { MTml } \\ 66 & \text { Quadro 10 } & 1 & \text { MBS } & \text { MTbp } \\ 68 & \text { Quadro 16 } & 1 & \text { MTP } & \text { MT+PS } \\ 68 & \text { Quadro 16 } & 1 & \text { MTC } & \text { MT+C } \\ 70 & \text { Tabela 1 } & 2 & \text { IC } & \text { IFc } \\ 71 & \text { Tabela 3 } & 4 & \text { CA } & \text { Ccha } \\ 71 & \text { Tabela 3 } & 4 & \text { Cm } & \text { CCt } \\ 72 & \text { Tabela 5 } & 2 & \text { TE } & \text { Tenf } \\ 72 & \text { Tabela 6 } & 5 & \text { CM } & \text { CEm } \\ 72 & \text { Tabela 6 } & 5 & \text { CA } & \text { CEa } \\ 72 & \text { Tabela 6 } & 5 & \text { MP } & \text { MPenf } \\ 72 & \text { Tabela 7 } & 2 & \text { CF } & \text { CCf } \\ 72 & \text { Tabela 7 } & 2 & \text { CH } & \text { CCh } \\ 75 & \text { Tabela 14 } & 4 & \text { MT } & \text { MTf } \\ 75 & \text { Tabela 14 } & 4 . & \text { PT } & \text { PTf }\end{array}$




\section{Dados Internacionais de Catalogação na Publicação (CIP) DIVISÃO DE BIBLIOTECA E DOCUMENTAÇĀO - ESALQ/USP}

Bizuti, Sérgio Fabrício Gonçalves

Enleiramento e enfardamento cilindrico de palhiço de cana-de-açúcar: alguns parâmetros de desempenho operacional e eficiência energética / Sérgio Fabrício Gonçalves Bizuti. - P Piracicaba, 2003

$$
75 \text { p. : il. }
$$

Dissertação (mestrado) - Escola Superior de Agricultura Luiz de Queiroz, 2003.

Bibliografia.

1. Cana-de-açúcar 2. Energia de biomassa 3. Enfardadoras 4. Instrumentos de precisāo 5. Mecanização agrícola I. Título

CDD 633.61 
" Se um homem tem um talento e não tem capacidade de usá-lo, ele fracassou.

Se ele tem um talento e usa somente a metade deste, ele fracassou parcialmente.

Se ele tem um talento e de certa forma aprende a usá-lo em sua totalidade, ele triunfou gloriosamente e obteve uma satisfação e um triunfo que poucos homens conhecerão ".

Aos meus pais, José Carlos Bizuti e Neuza Gonçalves Bizuti, Meus irmãos Júnior, Claúdio e Denise, dedico. 


\section{AGRADECIMENTOS}

Ao orientador e amigo, Prof. Tomaz Caetano Cannavam Ripoli pela orientação e compreensão durante o período percorrido para a finalização deste estudo.

Ao Prof. Dr. Walter Francisco Molina Jr. pelas sugestões e apoio de campo durante o desenvolvimento deste estudo.

À Escola Superior de Agricultura "Luiz de Queiroz" pela oportunidade de crescimento na minha formação profissional.

A Profa. Dra. Sonia Maria de Stefano Piedade pela ajuda no delineamento estatístico deste estudo.

Aos colegas de pós-graduação Domingos Guilherme Pellegrino Cerri, Fábio Henrique Rojo Baio, Hamilton Fernando Torrezan, Juliano C. Garcia Leal, Júlio César Dalla M. Esquerdo, Lucy Lancia Pereira e Marco Lorenzo C. Ripoli.

A todos aqueles que direta ou indiretamente contribuíram para a realização deste trabalho. 


\section{SUMÁRIO}

Página

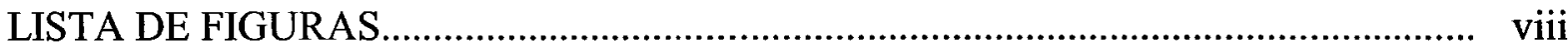

LISTA DE TABELAS.................................................................................. ix

LISTA DE ABREVIATURAS E SÍMBOLOS .......................................................... xii

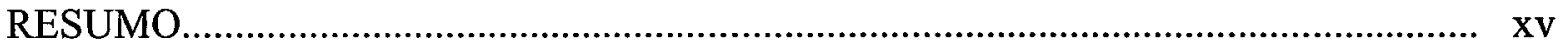

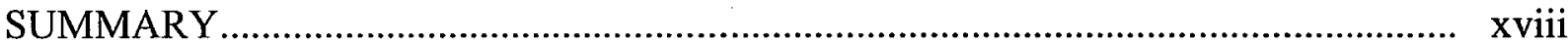

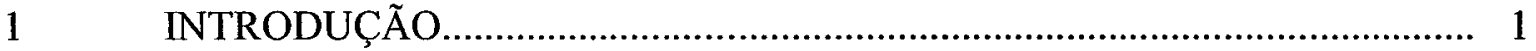

2 REVISÃO DE LITERATURA ....................................................... 2

2.1 Área cultivada, produção e colheita de cana-de-açúcar................................... 2

2.2 Impactos ambientais da cana queimada.............................................. 2

2.3 Cogeração e energia de biomassa............................................................... 6

2.4 Potencial energético da cana-de-açúcar e de outras fontes alternativas de

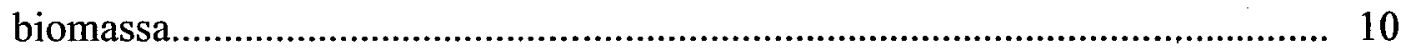

2.5 Desempenho operacional de enfardamento de palhiço de cana-de-açúcar......... 15

3 MATERIAL E MÉTODOS ................................................................. 21

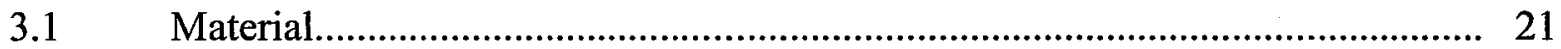

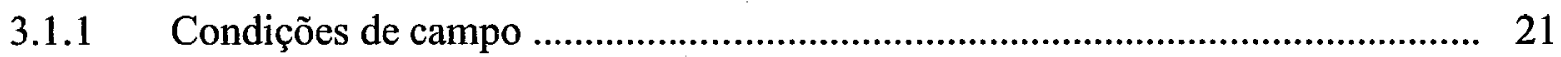

3.1.2 Variedade de cana-de-açúcar.................................................................... 21

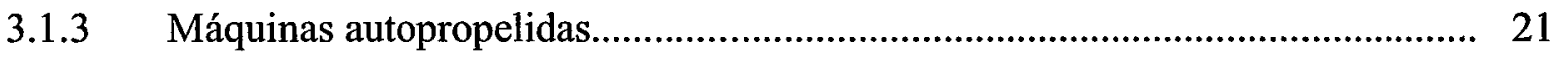

3.1.4 Ancinho enleirador........................................................................... 22

3.1.4.1 Enfardadora cilíndrica.................................................................... 23

3.2 Instrumentos para determinações ponderais, dimensionais e volumétricas....... 24

Material de laboratório.................................................................... 24

3.3.1 Instrumentos para determinações de umidade........................................... 24 
3.3.2 Instrumentos para determinação do poder calorífico e terra residual................ 25

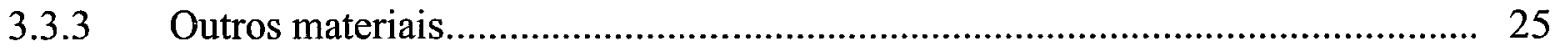

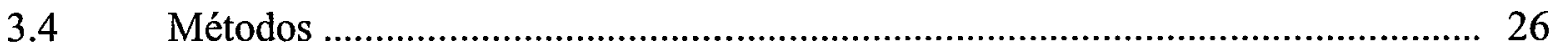

3.4.1 Caracterização do tipo de solo e umidade............................................. 26

3.4.2 Caracterização do palhiço......................................................................... 26

3.4.3 Preparação dos tratamentos.............................................................. 27

3.4.4 Determinação dos tempos e movimentos................................................ 27

3.4.5 Determinação do consumo de combustível no enleiramento.......................... 27

3.4.6 Determinação das áreas enleiradas......................................................... 27

Codificação dos tratamentos..................................................................... 28

3.5.1 Enfardamento............................................................................ 28

3.5.2 Determinação do consumo de combustível no enfardamento.......................... 29

3.5.3 Determinações dimensionais e ponderais dos fardos................................. 29

3.5.4 Caracterização do palhiço amostrado após o enfardamento.............................. 30

3.6 Determinações de laboratório........................................................... 32

3.6.1 Caracterização do material antes do enfardamento....................................... 32

3.6.2 Determinação da umidade antes do enfardamento........................................ 32

3.6.3 Determinação dos poderes caloríficos superior, inferior e útil....................... 33

3.7 Caracterização do material amostrado após o enfardamento......................... 34

3.7.1 Determinação da umidade após o enfardamento............................................ 34

3.7.2 Determinação ponderais de terra não aderida ao palhiço (amostras)................ 34

3.7.2.1 Terra não aderida ao palhiço................................................................ 34

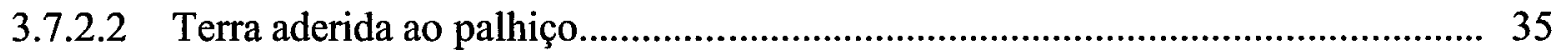

3.7.2.3 Avaliação das capacidades efetivas....................................................... 37

3.7.2.4 Balanço energético......................................................................... 37

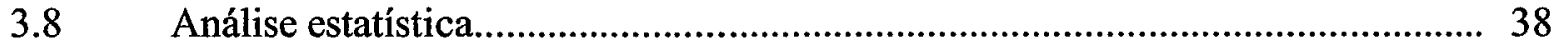

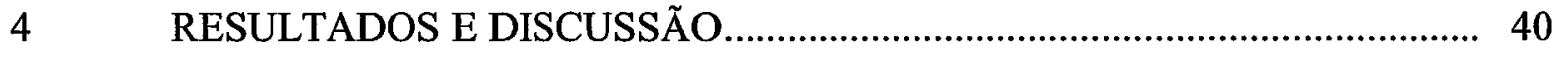

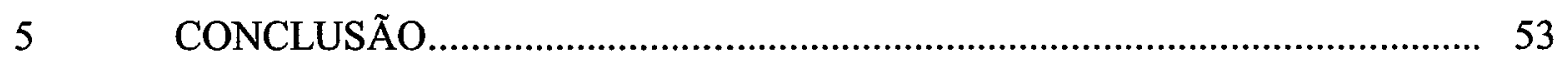

REFERENCIAS BIBLIOGRAFICAS 54 


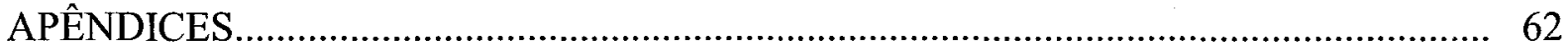




\section{LISTA DE FIGURAS}

Página

1 Ancinho enleirador em operação.............................................................. 22

2 Enfardadora Cilíndrica após ejeção do fardo...................................................... 23

3 Palhiço no campo após colheita mecanizada (A), Palhiço ensacado (B)................ 26

4 Medições dimensional (A) e ponderal (B) dos fardos......................................... 29

$5 \quad$ Operações de carregamento (A) e de transporte (B) dos fardos............................. 30

6 Amostragem para determinação da quantidade de terra junto ao palhiço enfardado. 31

$7 \quad$ Exemplo de amostra retirada por meio da sonda............................................. 32

8 Fluxograma da determinação, por peneiramento, da terra não aderida ao palhiço.... 35

9 Fluxograma da segunda etapa de determinação da terra não aderida ao palhiço....... 39

10 Percentagem dos constituintes do palhiço amostrado....................................... 42

11 Comparação de valores das capacidades efetivas obtidas neste estudo com os

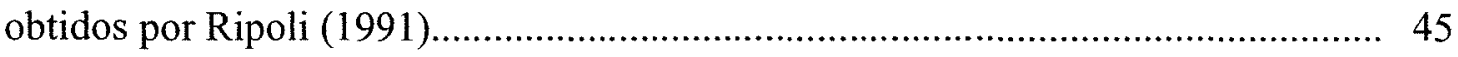

12 Comparação de valores das capacidades operacionais obtidas neste estudo com os

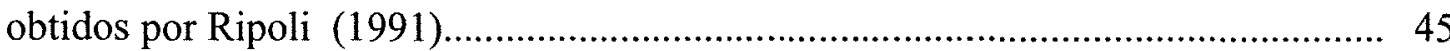

13 Valores comparativos entre os obtidos neste estudo com os encontrados por Ripoli (1991), para o consumo de combustível no enleiramento

14 Confronto referente a massa específica deste estudo com os citados na bibliografia, para diferentes marcas de enfardadoras. 


\section{LISTAS DE TABELAS}

Página

1 Produção de cana, bagaço e geração de energia elétrica no Estado de São Paulo e no Brasil, Nascimento \& Queiroz (1993)............................................................ 7

2 Consumo de energia " per capita " em alguns países. (FAO, 1989 citado por

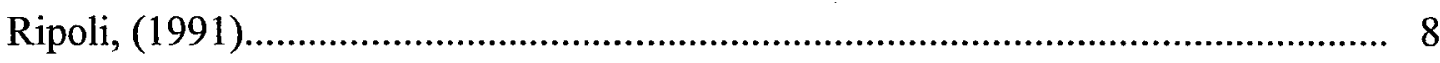

3 Poderes caloríficos de alguns materiais combustíveis, Staniforth (1982)................ 11

4 Energia potencial disponível em um canavial com estimativa de 60 t.ha $^{-1}$ de produtividade de colmos, Ripoli \& Molina Jr (1991)............................................. 12

5 Poderes caloríficos superior e inferior do palhiço, segundo Ripoli (1991).............. 12

6 Determinação da energia contida no palhiço, Furlani Neto et al. (1997)................... 14

7 Desempenho operacional do sistema, Lopez (1987)................................................ 16

8 Densidades das diferentes máquinas utilizadas no sistema, Lopez (1987)............... 16

9 Desempenhos operacionais das enfardadoras ensaiadas, Howe \& Sreesangkon

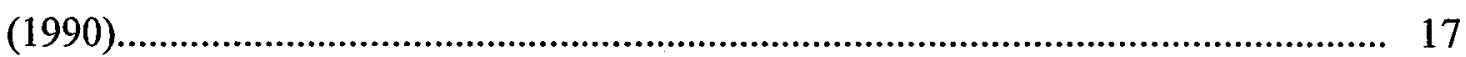

10 Parte dos resultados obtidos pela Copersucar (1991) ............................................. 18

11 Valores médios obtidos no estudo da Copersucar (1991)........................................ 18

12 Palhiço: Poderes caloríficos Superior (PCS); inferior (PCI) e útil (PCU) do resíduo, em kcal. $\mathrm{kg}^{-1}$; Massa de resíduo existente no campo após colheita (MRU) em t.ha ${ }^{-1}$; Umidade percentual do resíduo (U); e Potencial energético do resíduo (PER) em Mcal. ha ${ }^{-1}$ 
13 Massa dos fardos (Mfa) em kg; massa específica dos fardos (Dfa) em kg.m $\mathrm{m}^{-3}$; massa de palhiço enfardado (MEU) em t.ha ${ }^{-1}$ e teor de terra nos fardos (IM) em percentagem

14 Consumo de combustível da fonte de potência $(\mathrm{CCh})$, em $\mathrm{L}^{-1}{ }^{-1}$; desempenho operacional do conjunto (CCT e CCA) em t.h $\mathrm{h}^{-1}$ e t.ha ${ }^{-1}$; energia consumida pela fonte de potência na forma de combustível (ECE) em Mcal.ha ${ }^{-1}$; equivalente em energia no palhiço enfardado (EMR) em Mcal.ha ${ }^{-1}$.

15 Desempenhos médios, da operação de enleiramento Ripoli (1991)......................... 20

16 Análise granulométrica, umidade e tipo de solo.................................................... 40

17 Percentagens dos constituintes e produtividade estimada do palhiço , antes da operação de enleiramento. IF = índice de folhas; $\mathrm{IFc}=$ índice de frações de colmos; IPont = índice de ponteiros; $\mathrm{IM}=$ índice de matéria estranha total; $\mathrm{PE}=$ produtividade estimada.

18 Resultados de poderes caloríficos e umidade do palhiço. $\mathrm{U}=$ umidade; PCS = poder calorífico superior; $\mathrm{PCI}=$ poder calorífico inferior; $\mathrm{PCU}=$ poder calorífico útil; $\mathrm{PEP}=$ potencial energético do palhiço; $\mathrm{DP}=$ desvio padrão; $\mathrm{CV}=$ coeficiente de variação; $\mathrm{IC}=$ intervalo de confiança.

19 Resultados de desempenho operacional do ancinho enleirador. $\mathrm{CE}=$ capacidade efetiva; $\mathrm{CO}=$ capacidade operacional; $\mathrm{CCha}=$ consumo de combustível por hectare; $\mathrm{CCt}=$ consumo de combustível por tonelada; $\mathrm{BE}=$ balanço energético; $\mathrm{DP}=$ Desvio padrão; $\mathrm{CV}=$ Coeficiente de variação; $\mathrm{IC}=$ Intervalo de confiança...

20 Desempenho operacional do ancinho enleirador em ha.h ${ }^{-1}$. CE $=$ capacidade efetiva e $\mathrm{CO}=$ capacidade operacional.

21 Resultados de desempenho operacional da enfardadora. $\mathrm{DF}=$ densidade do fardo; $\mathrm{CE}=$ capacidade efetiva; $\mathrm{CCt}=$ consumo de combustível por tonelada; $\mathrm{BE}=$ balanço energético do enfardamento; $\mathrm{BT}=$ balanço energético do enleiramento $\mathrm{e}$ enfardamento; $\mathrm{MPenf}=$ massa estimada de palhiço enfardado; $\mathrm{Mpr}=\mathrm{CV}=$ coeficiente de variação; $\mathrm{IC}=$ intervalo de confiança 
22 Terra nos fardos (\%). TSf = terra solta no fardo; Tfolha $=$ terra aderida às folhas e palhas; $\mathrm{IM}=$ percentagem de terra no fardo; $\mathrm{CV}=$ coeficiente de variação; $\mathrm{IC}=$ intervalo de confiança...................................................................................... 51 


\section{LISTA DE ABREVIATURAS E SÍMBOLOS}

\begin{tabular}{|c|c|c|}
\hline $\mathrm{AE}$ & (ha) & área enleirada \\
\hline $\mathrm{AF}$ & (ha) & área estimada na formação do fardo \\
\hline $\mathrm{BE}$ & $(\%)$ & balanço energético \\
\hline BT & $(\%)$ & balanço energético do enfardamento e enleiramento \\
\hline $\mathrm{CA}$ & (m) & comprimento das áreas \\
\hline $\mathrm{CCf}$ & (L) & consumo de combustível por fardo \\
\hline $\mathrm{CCh}$ & $\left(L \cdot h^{-1}\right)$ & consumo de combustível por hora \\
\hline Ccha & $\left(\right.$ L.ha $\left.{ }^{-1}\right)$ & consumo de combustível por hectare \\
\hline $\mathrm{CCt}$ & $\left(\right.$ L.t $\left.t^{-1}\right)$ & consumo de combustível por tonelada \\
\hline $\mathrm{CE}$ & $\left(\right.$ t. $\left.h^{-1}\right)$ & capacidade efetiva \\
\hline $\mathrm{CEa}$ & $\left(h a \cdot h^{-1}\right)$ & capacidade efetiva em área \\
\hline CEm & $\left(\right.$ t. $\left.h^{-1}\right)$ & capacidade efetiva em massa \\
\hline $\mathrm{CO}$ & (t. $\left.\mathrm{h}^{-1}\right)$ & capacidade operacional \\
\hline CPL & $(\%)$ & cinzas de palhiço lavado \\
\hline $\mathrm{CV}$ & $(\%)$ & coeficiente de variação \\
\hline $\mathrm{DF}$ & $\left(\mathrm{kg} \cdot \mathrm{m}^{-3}\right)$ & massa específica do fardo \\
\hline DP & $(\%)$ & desvio padrão \\
\hline IC & $(\%)$ & intervalo de confiança \\
\hline IF & $(\%)$ & índice de folhas \\
\hline $\mathrm{IFc}$ & $(\%)$ & índice de frações de colmos \\
\hline $\mathrm{IM}$ & $(\%)$ & índice de matéria estranha mineral \\
\hline IPont & $(\%)$ & índice de ponteiros \\
\hline IPS & $(\%)$ & índice de palhiço da sub-amostra em base seca \\
\hline
\end{tabular}




$\begin{array}{lll}\text { IPU } & (\%) & \text { índice de palhiço da sub-amostra em base úmida } \\ \text { LFE } & (\mathrm{m}) & \text { largura da faixa de enleiramento } \\ \text { LME } & (\mathrm{m}) & \text { largura media da faixa enleirada } \\ \text { LTA } & (\mathrm{m}) & \text { largura total da área } \\ \text { LUA } & (\mathrm{m}) & \text { largura útil da área } \\ \text { MA } & (\mathrm{kg}) & \text { massa da amostra } \\ \text { MC+T } & (\mathrm{kg}) & \text { massa de cinzas mais terra nas amostras não lavadas } \\ \text { MF } & (\mathrm{kg}) & \text { massa do fardo } \\ \text { MFc } & (\mathrm{kg}) & \text { massa de frações de colmos } \\ \text { MIM } & (\mathrm{kg}) & \text { massa de matéria estranha mineral } \\ \text { MP } & (\mathrm{kg}) & \text { massa de ponteiros } \\ \text { Mpe } & (\mathrm{t}) & \text { massa estimada de palhiço enleirado } \\ \text { MPenf } & \left(\mathrm{t} . h a^{-1}\right) & \text { massa estimada de palhiço enfardado } \\ \text { MPS } & (\mathrm{kg}) & \text { massa de palhiço triturado em base seca } \\ \text { MS } & (\mathrm{kg}) & \text { massa em base seca da sub-amostra da sonda } \\ \text { MT } & (\mathrm{kg}) & \text { massa de terra com partículas orgânicas } \\ \text { MT+C } & (\%) & \text { massa de terra mais cinzas } \\ \text { MT+PS } & (\mathrm{kg}) & \text { massa de terra mais particulado vegetal em base seca } \\ \text { MTbp } & (\mathrm{kg}) & \text { massa de terra obtida por meio da bateria de peneiras } \\ \text { MTf } & (\mathrm{kg}) & \text { massa de terra no fardo } \\ \text { MTml } & (\mathrm{kg}) & \text { massa de terra por meio de peneira de malha larga } \\ \text { UM } & (\mathrm{kg}) & \text { massa em base úmida da sub-amostra da sonda } \\ \text { PCI } & \left(\mathrm{MJ} . \mathrm{kg}^{-1}\right) & \text { Poder Calorifico Inferior } \\ \text { PCS } & \left(\mathrm{MJ} . \mathrm{kg}^{-1}\right) & \text { Poder Calorifico Superior } \\ \text { PCU } & \left(\mathrm{MJ} . \mathrm{kg}^{-1}\right) & \text { Poder Calorifico Útil } \\ \text { PE } & \left(\mathrm{t} . h a^{-1}\right) & \text { produtividade estimada } \\ \text { PEP } & \left(\mathrm{MJ} . \mathrm{kg}^{-1}\right) & \text { potencial energético do palhiço } \\ \text { PF } & (\mathrm{m}) & \text { percurso de enfardamento } \\ \text { PT+C } & (\%) & \text { percentagem de terra e cinzas } \\ & & \\ \text { MP } & & \end{array}$




$\begin{array}{lll}\text { PTf } & (\%) & \text { percentagem de terra no fardo } \\ \text { TA } & (\%) & \text { terra na amostra } \\ \text { TEenl } & (\mathrm{s}) & \text { tempo efetivo no enleiramento } \\ \text { Tenf } & (\mathrm{s}) & \text { tempo de enfardamento } \\ \text { Tfolha } & (\%) & \text { terra aderida às folhas e palhas } \\ \text { TMenl } & (\mathrm{s}) & \text { tempo de manobra no enleiramento } \\ \text { U } & (\%) & \text { Umidade } \\ \text { VE } & \left(\mathrm{km} \cdot \mathrm{h}^{-1}\right) & \text { velocidade de enfardamento } \\ \text { VF } & \left(\mathrm{kg} \cdot \mathrm{m}^{-3}\right) & \text { volume do fardo }\end{array}$




\title{
ENLEIRAMENTO E ENFARDAMENTO CILÍNDRICO DE PALHIÇO DE CANA-DE-AÇÚCAR: ALGUNS PARÂMETROS DE DESEMPENHO OPERACIONAL E EFICIÊNCIA ENERGÉTICA
}

\author{
Autor: SÉRGIO FABRÍCIO GONÇALVES BIZUTI \\ Orientador: Prof. Dr. TOMAZ CAETANO C. RIPOLI
}

\section{RESUMO}

O objetivo deste estudo foi o de analisar o recolhimento do palhiço de cana-deaçúcar do ponto de vista operacional, bem como determinar seu potencial energético, utilizando-se de um ancinho enleirador de roda de terra e de uma enfardadora de forragem de fardos cilíndricos, sob dois diferentes tipos de enleiramentos (simples e duplo). Os ensaios de campo foram realizados no município de Piracicaba, SP, em área comercial do GRUPO COSAN-COSTA PINTO. As coordenadas geográficas do ponto central da área de ensaio são: $22^{\circ} 40^{\prime \prime} 3$ ' de latitude Sul, 47036"33' de longitude oeste e altitude de $605 \mathrm{~m}$. Da análise do palhiço antes do enfardamento foram determinados, como resultados médios: Índices de folhas $=69,93 \%$, de frações de colmos $=2,27 \%$, de ponteiros $=21,44$, de matéria estranha mineral total $=6,36 \%$, enquanto que a produtividade estimada de palhiço foi de 27,01 tha ${ }^{-1}$, com Poderes Calorificos Superior de 18,43 MJ.kg ${ }^{-1}$, Inferior de 17,01 MJ.kg ${ }^{-1}$, Útil de 13,32 ${\mathrm{MJ} . \mathrm{kg}^{-1}}^{-1}$, umidade média =

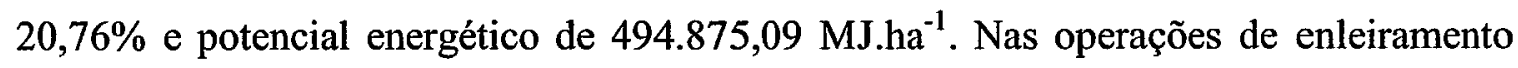
(simples e duplo) as médias das variáveis testadas: capacidade efetiva, capacidade operacional, consumo de combustível horário e por tonelada enfardada e balanço energético, diferiram entre si ao nivel de $1 \%$ por meio do teste de Tukey. As operações 
de enfardamento foram executadas sobre dois tipos de enleiramentos (simples e duplo), sendo analisadas as variáveis: massa específica dos fardos, capacidade efetiva, consumo de combustível por tonelada enfardada, massa estimada de palhiço enfardada, massa estimada de palhiço remanescente, balanço energético do enfardamento e balanço energético de enleiramento mais enfardamento. A comparação das médias dos resultados obtidos da massa específica dos fardos e as capacidades efetivas (t. $\left.\mathrm{h}^{-1}\right)$ e $\left(\mathrm{ha} . \mathrm{h}^{-1}\right)$ foram significativas ao nível de $5 \%$ pelo teste de Tukey. As comparações das médias para os balanços energéticos foram significativas ao nível de $1 \%$. As médias da quantidade de terra nos fardos não diferiram entre si nos tratamentos estudados.

Palavras chave: cana-de-açúcar, energia de biomassa, palhiço. 


\title{
WINDROWING AND CILINDRICAL BALING OF SUGARCANE TRASH: OPERATIONAL ACTING PARAMETERS AND ENERGY EFFICIENCY
}

\author{
Author: SÉRGIO FABRÍCIO GONÇALVES BIZUTI \\ Adviser: Prof. Dr. TOMAZ CAETANO C. RIPOLI
}

\section{SUMMARY}

The objective of this study was analyze the withdrawal of the straw of sugar-cane of the operational point of view, as well as to determine its energy potential, using a rake and one cylindrical forage baler, under two different windrowing types (simple and double). The field tests were performed in the municipal district of Piracicaba, SP in commercial area of the GRUPO COSAN-COSTA PINTO. The geographical coordinates of the central point of the tests area are: $22^{\circ} 40^{\prime \prime} 3^{\prime}$ of South latitude, $47^{\circ} 36^{\prime \prime} 33^{\prime}$ of longitude was and altitude of $605 \mathrm{~m}$. Of the analysis of the straw before the baling were determinated, as medium results: Indexes of leaves $=69,93 \%$, of stalks fractions $=$ $2,27 \%$, of pointers $=21,44$, of matter find strange total mineral $=6,36 \%$, while the dear

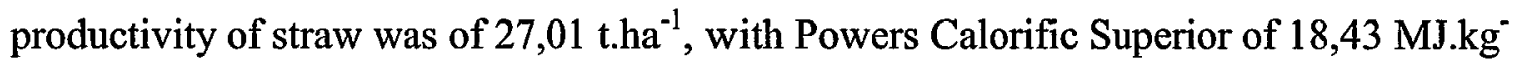
${ }^{1}$, Useful of $13,32 \mathrm{MJ} . \mathrm{kg}^{-1}$ Inferior of $17,01 \mathrm{MJ} \cdot \mathrm{kg}^{-1}$, medium humidity $=20,76 \%$ and energy potential of $494.875,09 \mathrm{MJ}^{-1} \mathrm{ha}^{-1}$. In the windrowing operations (simple and double) the averages of the tested variables: effective capacity, operational capacity, in consumption of hourly fuel and for ton baled and energy swinging, they differed to each other at the level of $1 \%$ by means of the test of Tukey. The baling operation was executed on the two windrowing types (simple and double), being tested its variables: specific mass of the bales, effective capacity, I consummate of fuel for ton baled, dear 
mass of straw baled, dear mass of remaining straw, energy swinging of the baling and energy swinging of windrowing more baling. The comparison of the averages of the obtained results of the specific mass of the bales and the effective capacities $\left(t \cdot h^{-1}\right)$ and $\left(\right.$ ha. $h^{-1}$ ) they were significant at the level of $5 \%$ for the test of Tukey. The comparisons of the averages for the energy swingings were significant at the level of $1 \%$. The averages of the amount of earth in the bales didn't differ to each other in the studied treatments.

Keywords: sugar cane, biomass energy, baling, harvesting, straw. 


\section{INTRODUÇÃO}

O setor sucroalcooleiro do Brasil é a principal fonte de biomasssa energética do país. Para 2003, prevê-se uma área cultivada perto de cinco milhões de hectares, com uma produção aproximada de 326 milhões de toneladas de colmos industrializáveis de cana-de-açúcar. Hoje ainda, existe nos canaviais brasileiros o uso da queima como prática da pré-colheita, entretanto, a sociedade exerce uma pressão para à eliminação dessa prática, nas proximidades das cidades, e pela existência da lei 11341 que impõe prazos para a eliminação do uso do fogo na colheita da cana-de-açúcar. A queima da cana-de-açúcar faz com que haja uma grande perda de biomassa, que poderia ser utilizada para a co-geração de energia elétrica nas usinas e destilarias, além disso, a queima dos canaviais gera grandes impactos ambientais.

Há a necessidade de sistemas de recolhimento que possam permitir o aproveitamento do palhiço de cana-de-açúcar para fins energéticos, e transformar as usinas e destilarias em grandes produtoras de energia elétrica por meio da co-geração.

O objetivo do presente estudo visou avaliar parâmetros de desempenho operacional das operações de enleiramento e enfardamento cilíndrico sobre palhiço de cana-de-açúcar e suas eficiências energéticas.

A hipótese de trabalho do estudo foi a de que é viável o recolhimento do palhiço de cana-de-açúcar, colhida sem queima prévia, do ponto de vista operacional, bem como determinar seu potencial energético, utilizando-se de um ancinho enleirador e de uma enfardadora de forragem de fardos cilíndricos, sob dois diferentes tipos de enleiramentos (simples e duplo). 


\section{REVISÃO DE LITERATURA}

\section{1 Área cultivada, produção e colheita de cana-de-açúcar}

Historicamente a cana-de-açúcar é um dos principais produtos agrícolas do Brasil, sendo cultivada desde a colonização do país. Dessa matéria-prima produz-se o açúcar e o álcool (anidro e hidratado), entre outros produtos e, como subprodutos, o vinhoto, o bagaço e o palhiço entre outros. A cana-de-açúcar é uma cultura que gera uma grandeza de biomassa energética que nenhuma outra cultura apresenta (CENBIO, 2002a).

O Estado de São Paulo é o maior produtor de açúcar e de álcool do País. Do total da safra do Centro - Sul de 2002/2003, o Estado foi responsável por 60\% da produção de açúcar, com 190 milhões de toneladas e, em álcool chegou a 7,6 milhões de metros cúbicos, segundo o jornal, O ESTADO DE SÃO PAULO (2003).

A produção brasileira de cana-de-açúcar na safra $2001-2002$ foi de $285,77.10^{6}$ de toneladas em área de $4,73.10^{6}$ hectares segundo a FNP (2003). Para a safra de 20022003 estimou-se uma produção de $326,76.10^{6}$ toneladas de colmos, com uma área colhida de $4,96 \cdot 10^{6}$ hectares.

\subsection{Impactos ambientais da cana queimada}

Delgado (1985) cita aspectos favoráveis e desfavoráveis em relação a prática da queima de canaviais, precedente à colheita, classificadas sob vários aspectos, arrolados a seguir: 
Agronômicos :

- palhiço incorporado ao solo aumentando o teor de matéria orgânica;

- destruição dos inimigos da broca da cana;

- facilidade nas operações de solo e de cultivo;

- eliminação das pragas da cultura;

- facilidade nas operações tanto de corte manual como mecanizados.

Industriais:

- dificulta a conservação e a purificação dos caldos;

- aumenta o brix e a percentagem de fibra da cana devido ao secamento dos colmos;

- aumenta a infestação de microorganismos nos colmos, através da exsudação;

- apresenta-se econômico e operacional:

- agiliza a colheita;

- causa prejuízos, devido ao atraso do corte;

- traz complicações para o tratamento de água de lavagem, pelo aumento de volume e pela demanda biológica de oxigênio, devido ao exsudado e pela solubilização de ceras.

- mostra-se energético:

- causa perdas da matéria bruta, que poderiam ser usadas para a produção de biogás ou queimadas nas caldeiras gerando energia através de biomassa.

Ripoli (1988) considera que a queima prévia dos canaviais deve ser caracterizada em função dos reflexos econômicos imediatos. Vários inconvenientes decorrem dessa prática, tais como os riscos de descontrole do fogo, com a possibilidade de provocar incêndios em outras áreas agrícolas ou em matas; os danos às redes elétricas, as dificuldades na implantação de controle biológico de pragas, a perda de sacarose por

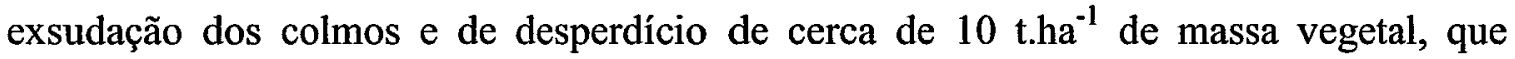
poderia ser incorporada ao solo, melhorando suas propriedades físico-químicas ou aproveitada como fonte de energia na agroindústria. 
Furlani Neto (1994) compara a cana crua com a queimada e destaca para a cana crua as vantagens de proteger o solo contra a erosão, de reduzir o uso de herbicidas, de melhorar a matéria-prima para a indústria, de possibilitar maior incorporação de matéria orgânica ao solo, de ajudar na atividade microbiana do solo e de reduzir a poluição ambiental. Há também desvantagens como por exemplo, o aumento do ataque de pragas como as cigarrinhas da raiz (Mahanarva fimbriolata), as brocas e as doenças (podridões), favorecidas pela presença da palha no solo durante a fase inicial de crescimento, a irregularidade de brotação sobre o palhiço, a dificuldade de utilização em áreas não mecanizáveis e a necessidade obrigatória de colhedora, dada a difícil utilização de corte manual em canaviais sem queimar.

Ripoli (1995) cita os impactos ambientais da queima de cana-de-açúcar na précolheita, afirmando que a queima é uma agressão ao ambiente, causando desequilíbrios biológicos e podendo aumentar a utilização de agroquímicos na cultura da cana-deaçúcar, por outro lado, facilita o corte manual e mecanizado reduzindo a quantidade de matéria - estranha na matéria-prima colhida.

Ripoli et al. (1997) citam que a prática da queima de pré-colheita é consagrada por favorecer o aumento no desempenho operacional de colhedoras e de trabalhadores braçais além de reduzir a matéria estranha vegetal que acompanha a matéria-prima. $\mathrm{Na}$ contrapartida, tal prática, como já comprovado por pesquisas desenvolvidas no INSTITUTO NACIONAL DE PESQUISAS ESPACIAIS - INPE (1997), aumenta, sensivelmente, as taxas de monóxido de carbono e de ozônio na baixa atmosfera, o que vai de encontro à pressão da sociedade contra práticas que agridem o ambiente, cada vez mais presente. Numa outra vertente, deve-se considerar que o Brasil, um país carente de energia disponível e de pronta utilização pela população, não pode se dar ao luxo de desprezar a enorme quantidade de energia existente no palhiço da cana-de-açúcar, queimado como prática de pré-colheita.

Alvarez \& Castro (1999) analisaram a comparação do crescimento de cana colhida crua, mecanizada e de cana após a queima, colhida manualmente além de avaliar a influência do clima sobre as duas condições de crescimento. Por fim, estudaram o comportamento do crescimento de cana crua e da cana queimada nos $1^{\circ}$ e $2^{\circ}$ anos de 
rebrota, através de curvas adaptadas. Concluíram que o crescimento no primeiro ciclo foi semelhante, para a cana crua e para a queimada. No início do segundo ciclo, todavia, ocorreu maior desenvolvimento na cana crua, enquánto, no final, o crescimento foi maior na cana queimada. O perfilhamento da cana crua não apresentou diferenças significativas que confirmassem a influência negativa da palha na rebrota. De um modo geral, os fatores climáticos, isoladamente, não provocam mudanças na comparação entre os índices biométricos de cana crua e de cana queimada, em seus ciclos de crescimento. As diferenças expressas na curva de crescimento, do primeiro para o segundo ano, são devidas aos fatores climáticos, tanto para a cana crua como para a queimada.

Bassinello et al. (s.d.) citam aspectos favoráveis e desfavoráveis da cana-deaçúcar como matéria-prima de canaviais, sem queima prévia, devido aos restos culturais (palha e palmito) no campo. Como aspectos favoráveis, os autores citam a manutenção da umidade do solo, o controle de plantas daninhas, sem a utilização ou com a diminuição da quantidade de herbicidas aplicados, o melhor controle de erosão com proteção do solo contra o impacto das gotas de chuva, o aumento de matéria orgânica no solo pela adoção da prática por vários anos, a redução da população de nematóides nocivos à cultura, pelo acréscimo de nematóides predadores e microorganismos resultantes do aumento da matéria orgânica no solo, a possibilidade do melhor aproveitamento da cana-de-açúcar do ponto de vista energético, levando-se toda a fonte de energia (biomassa) para a indústria, a melhoria da quantidade de matéria-prima entregue para a industrialização. Como aspectos desfavoráveis, os autores citam a dificuldade de mão-de-obra disponível para a adoção da técnica e a resistência do próprio cortador em executá-la, o rendimento de corte menor, tanto manual como mecânico, implicando maiores custos de produção, o aumento de impurezas vegetais e minerais na matéria-prima, a tendência de apresentar o corte basal mais elevado, provocando perdas de matéria-prima e prejudicando a brotação da soqueira, a maior dificuldade de brotação da soqueira, devido à menor temperatura do solo e ao sombreamento, o maior foco de infestação para o alojamento de pragas, a impossibilidade de utilização dos implementos tradicionais nos tratos culturais de adubação e cultivo (subsolagem), a necessidade de maior quantidade de nitrogênio na 
adubação de soqueira com a finalidade de suprir a parte imobilizada na decomposição da palha e a aplicação do plantio de todo o fósforo exigido para o ciclo da cultura, o perigo de fogo acidental no período de entressafra e de colheita, a maior velocidade de deterioração da cana crua, em relação à cana queimada, após o corte, o cuidado na escolha de variedades apropriadas (sem joçal, despalha fácil, com menor problema de doenças e brocas), o aumento da necessidade de transporte pela empresa, a diminuição da velocidade das colhedoras, com o aumento do consumo operacional e do custo final.

\subsection{Energia de biomassa}

Segundo Brito (1986), a biomassa pode constituir a base de um modelo de desenvolvimento tecnológico e industrial auto-sustentado, baseado em dados concretos da realidade regional e na integração do homem em um ambiente econômico harmonioso com seu ambiente natural, além de ser uma simples fonte de energia alternativa. Como o componente energético é quem molda e sustenta as civilizações, pode-se concluir que existem amplas oportunidades a uma participação efetiva dos combustíveis derivados de biomassa no Brasil e na América Latina, havendo, portanto, a necessidade de clara opção política e de esforço tecnológico mais autônomo tendo, como vetores de energia, o etanol, os óleos vegetais e a biomassa na propulsão de veículos, na geração de empregos e na cogeração de energia elétrica.

Relatando experiências, das últimas cinco safras, na Usina Central Romana, na República Dominicana, com o recolhimento e a utilização de material remanescente de colheita de cana-de-açúcar, como fonte de energia para a geração de eletricidade, Lopez (1987) cita que, no momento da colheita, a parte constituída pelos ponteiros e folhas representa $30 \%$ em peso, da parte aérea, variando no entanto, conforme cultivar e as condições de cultivo podendo representar, em alguns casos, apenas 15\%. A umidade desse material segundo o autor, pode diminuir em períodos menores que uma semana, para $30 \%$ com dias ensolarados, sendo freqüente encontrar-se umidades inferiores a $20 \%$. O poder calorífico do resíduo de colheita, com base em peso seco, é da ordem de 4180 kcal.kg-1 e de $2850 \mathrm{kcal} . \mathrm{kg}^{-1}$, com $30 \%$ de umidade. $\mathrm{O}$ autor conclui como 
satisfatório o resultado do recolhimento do material remanescente, tanto do ponto de vista operacional quanto do econômico.

Nascimento \& Queiroz (1993) apresentaram um trabalho cujo objetivo foi mostrar os princípios técnicos e as tecnologias disponíveis para a gaseificação de bagaço de cana-de-açúcar e de outras biomassas, com a utilização do gás produzido, como combustível, para a geração de termoeletricidade sob condições de altos rendimentos e baixos custos de investimentos. O potencial de geração e comercialização de energia elétrica oriunda desta atividade é mostrada na Tabela 1.

Tabela 1. Produção de cana, bagaço e geração de energia elétrica no Estado de São Paulo e no Brasil, Nascimento \& Queiroz (1993)

\begin{tabular}{lcc}
\hline & São Paulo & Brasil \\
\hline Produção - tca & 137.281 .272 & 218.338 .000 \\
Bagaço gerado - tbg.ano ${ }^{-1}$ & 39.800 .000 & 63.300 .000 \\
Geração de energia elétrica - (MW) & & \\
Safra & 5.200 & 8.300 \\
Entre-safra & 4.000 & 6.400 \\
Venda de energia elétrica -(MW) & & \\
Safra & 4.000 & 6.400 \\
Entre-safra & 4.000 & 6.400 \\
\hline
\end{tabular}

tca $=$ tonelada de cana. ano $^{-1}$ e tbg $=$ tonelada de bagaço

Zarpelon (1993) cita que a produção de energia elétrica em usina de açúcar, para a venda às concessionárias, não é algo recente. As usinas havaianas, há mais de 40 anos, são produtoras de energia elétrica para as comunidades e especialmente a partir dos anos 70, modificaram suas fábricas e passaram a fornecer grandes quantidades de energia o ano inteiro, mesmo no período de entressafra. Em 1986, havia 12 usinas havaianas fornecendo um equivalente a $453 \mathrm{mil}$ MWh (50\% do total gerado nas usinas) para as concessionárias locais, correspondendo a $10 \%$ do total consumido no estado do Havaí. Na ilha de Kauai, 55\% da energia é suprida pelas usinas de açúcar. No ano de 1986, as 15 usinas de açúcar da ilha de Maurício (Mauritius) supriram 115 mil MWh à rede pública, correspondendo a $26 \%$ da energia utilizada.

Ripoli et al.(2000) citam que um dos caminhos para medir o desenvolvimento de um país é examinar o consumo de energia "per capita", já que existe uma correlação 
muito forte entre desenvolvimento e disponibilidade de energia. A Tabela 2 mostra o consumo de energia em quatro países de diferentes patamares de desenvolvimento econômico.

Tabela 2. Consumo de energia " per capita" em alguns países. (FAO, 1989 citado por Ripoli, 1991)*

\begin{tabular}{ccccc}
\hline Países & $\begin{array}{c}\text { Barril de } \\
\text { petróleo }\end{array}$ & $\begin{array}{c}\text { Eletricidade } \\
(\mathrm{kWh})\end{array}$ & $\begin{array}{c}\text { Carvão } \\
(\mathrm{t} \text { métrica })\end{array}$ & $\begin{array}{c}\text { Gás natural } \\
\left(\mathrm{m}^{3}\right)\end{array}$ \\
\hline USA & 19,2 & 11,139 & 3,1 & 2,047 \\
Austrália & 11,0 & 8,224 & 5,3 & 983 \\
Brasil & 3,0 & 1,519 & 0,1 & 19 \\
Índia & 0,4 & 272 & 0,2 & 80 \\
\hline
\end{tabular}

(*)Ripoli, T. C. C.

Segundo a Única (2001), o vapor obtido pela queima do bagaço da cana, movimenta turbinas, gerando energia elétrica que torna auto-suficientes as unidades industriais e os excedentes são vendidos às concessionárias. No Estado de São Paulo, o setor gera para consumo próprio entre 1.200 e $1.500 \mathrm{MW}$. Excedentes de $158 \mathrm{MW}$ são transferidos por 40 usinas e a energia que vem da cana já ajuda a iluminar diversas cidades. $O$ potencial de geração de energia da agroindústria canavieira está em torno de 12 mil MW - a potência total instalada no Brasil é de 70 mil MW. Em 2002, em função de novos projetos, mais $300 \mathrm{MW}$ devem ser adicionados e em curto prazo o setor poderá contribuir com 4 mil MW adicionais.

O Jornal de Piracicaba (2001) noticiou que a cogeração de energia produzida pelo bagaço de cana pode ser uma grande aliada contra a falta de energia e ao aumento dos preços do produto. Utilizando uma matéria-prima (palhiço) que antes não tinha uma função específica, as unidades industriais tanto podem economizar na conta de energia, quanto vender o excedente. Para que as usinas possam comercializar essa energia, seria necessário a transformação das turbinas convencionais para turbinas específicas de condensação. Tal mudança poderia trazer benefícios tanto para a venda da energia excedente, quanto para a produção de açúcar e de álcool, e poderia chegar a um rendimento de $15 \%$ para os dois produtos. 
Segundo o INSTITUTO NACIONAL DE EFICIÊNCIA ENERGÉTICA - INEE (2002), por mais eficiente que seja um gerador termelétrico, a maior parte da energia contida no combustível usado para seu acionamento é transformada em calor e perdida para o ambiente. Trata-se de uma limitação física que independe do tipo de combustível (diesel, gás natural, carvão, etc.) ou do motor (a explosão, turbina a gás ou a vapor etc.): no máximo $40 \%$ da energia do combustível do diesel usado em um gerador podem ser transformados em energia elétrica. Como muitas indústrias e prédios comerciais necessitam de calor (vapor ou água quente), foi desenvolvida uma tecnologia denominada cogeração, em que o calor produzido na geração elétrica é usado no processo produtivo sob a forma de vapor. A vantagem é que o consumidor economiza o combustível de que necessitaria para produzir o calor do processo. A eficiência energética é, desta forma, bem mais elevada, por tornar úteis até $85 \%$ da energia do combustível. O inconveniente da cogeração é que o calor só pode ser usado perto do equipamento, o que limita essas instalações a unidades relativamente pequenas se comparadas com os geradores das concessionárias. Até meados do século $\mathrm{XX}$, a cogeração chegou a ser muito usada nas indústrias, perdendo depois a competitividade para a eletricidade produzida pelas concessionárias, nas grandes centrais geradoras com ganhos de escala. Assim, a cogeração ficou limitada a sistemas isolados (plataformas submarinas) e indústrias com lixos combustíveis (canavieira e de papel e celulose, por exemplo).Nos últimos quinze anos, porém, um novo modelo do setor elétrico voltou a estimular a produção elétrica local a que fosse mais eficiente e de baixo custo, levando ao aperfeiçoamento da tecnologia da cogeração. A necessidade de reduzir emissões de $\mathrm{CO}_{2}$ também incentivou a adoção desse eficiente processo.

A atual crise de energia traz de volta a necessidade da introdução de novas fontes de energia primária na Matriz Energética Nacional. Isso representa a base do programa prioritário de termelétricas, estudado pelo Ministério de Minas e Energia. Em 2001, sabe-se que das 49 térmicas previstas, apenas 11 se apresentaram viáveis no curto e no médio prazos. Nesse contexto, a utilização de outras fontes de energia, em particular a biomassa (resíduos de cana-de-açúcar e de madeira, além da casca de arroz), aparecem 
como uma oportunidade de particular importância para colaborar na oferta de energia do sistema interligado do país (CENBIO, 2002c).

\subsection{Potencial energético da cana-de-açúcar e de outras fontes alternativas de biomassa}

Segundo Brito \& Barrichello (1982), o Poder Calorífico de materiais vegetais pode ser considerado de duas formas: Superior (PCS), se é considerado o calor liberado pela condensação da água de constituição do combustível ou Inferior (PCI) quando tal consideração não é feita.

Poder Calorífico Inferior (PCI) é definido por Oliveira (1982) como o calor liberado pelo combustível, menos o calor de vaporização da água, que é de $600 \mathrm{kcal}$ para $1 \mathrm{~kg}$ de água. O peso da água formada na condensação é nove vezes o peso do hidrogênio encontrado no combustível.

Lanças (1984) cita as vantagens e os problemas na evolução da utilização das alternativas energéticas, como a biomassa, em larga escala, descritas a seguir:

- recursos renováveis e disponíveis em diversas formas e grande variedade de uso;

- recursos regionais e locais mais apropriados para a produção descentralizada;

- diminuição da poluição ambiental em relação aos combustíveis fósseis;

- problemas de armazenamento e de transporte devidos às várias formas de biomassa;

- para melhor eficiência é necessário um sistema de pré-secagem devido à umidade da biomassa;

- com a produção descentralizada, a necessidade de transporte para os centros de conversão pode tornar inviável sua produção, dependendo das distâncias.

A norma 8633, ASSOCIAÇÃO BRASILEIRA DE NORMAS TÉCNICAS, (ABNT 1984), designa o Poder Calorífico Superior como uma unidade de calor liberada pela combustão de uma unidade de massa de uma substância, em bomba calorimétrica, 
em atmosfera de oxigênio, a volume constante e sob condições específicas de modo que toda a água proveniente da combustão esteja no estado líquido.

Staniforth (1982) compara alguns tipos de materiais combustíveis, mensurandoos em seus poderes caloríficos. Os valores são encontrados na Tabela 3.

Tabela 3. Poderes caloríficos de alguns materiais combustíveis, Staniforth (1982)

\begin{tabular}{lc}
\hline Materiais & $\begin{array}{c}\text { Poder calorífico } \\
\left(\mathrm{Mj} . \mathrm{kg}^{-1}\right)\end{array}$ \\
\hline Palha, com 15\% de umidade & 15 \\
Madeira, com $15 \%$ de umidade & 15 \\
Carvão de boa qualidade & 30 \\
Óleo combustivel & $40-45$ \\
\hline
\end{tabular}

Ripoli et al. (1990a) determinaram a média da massa de material remanescente de colheita de palhiço como 9,7 tha ${ }^{-1}$ e o Poder Calorífico Útil (PCU), da ordem de $2.280 \mathrm{kcal} . \mathrm{kg}^{-1}$. Estimaram que, de um canavial com produtividade de colmos de 70 t.ha ${ }^{1}$, pode-se obter um equivalente energético de 20.877Mcal em etanol; 31.326 Mcal no bagaço e 21.058 Mcal no material remanescente da colheita (palhiço).

Ripoli et al. (1990b) pesquisando no Brasil às variedades SP701248, SP706163 e SP701143, determinaram relações entre colmos industrializáveis e palhiço (ponteiros, folhas verdes e palha), ao que chamaram de Índice de Palhiço; das frações do palhiço entre si, denominadas de composição percentual de palhiço e determinaram o poder calorífico superior para cada uma das frações do palhiço assim como seus teores de hidrogênio e seu grau de umidade. Concluíram que não há diferença significativa entre o poder calorífico dos colmos industrializáveis e o poder calorifico superior das frações do palhiço, podendo ser considerado em média , como $4300 \mathrm{kcal}^{\mathrm{kg}}{ }^{-1}$, para efeito prático, enquanto a percentagem de hidrogênio elementar $(H)$ no material foi, em média, de $6,34 \%$, para folhas verdes. Também a composição percentual de palhiço mostrou-se uniforme e para efeito prático, pode ser considerada como 1/3 para cada uma delas. $\mathrm{O}$ Índice de Palhiço, no entanto mostrou-se desuniforme, sendo as médias encontradas para as variedades, as seguintes: $\mathrm{SP} 701248=17,4 \%, \mathrm{SP} 701143=25,2 \%, \mathrm{SP} 706163=$ $31,5 \%$. 
Ripoli \& Molina Jr (1991) estimaram que, de em um canavial com 60 t.ha ${ }^{-1}$ de matéria-prima, é possivel obter-se $67.080 \mathrm{Mcal}$ de energia, sendo distribuída conforme apresentado na Tabela 4.

Tabela 4. Energia potencial disponível em um canavial com estimativa de 60 t.ha $^{-1}$ de produtividade de colmos, segundo Ripoli \& Molina Jr (1991)

\begin{tabular}{lccc}
\hline Álcool & $4500 \mathrm{~L}$ & $16.830 \mathrm{Mcal}$ & $25,09 \%$ \\
Bagaço & $15 \mathrm{t}$ & $26.850 \mathrm{Mcal}$ & $40,03 \%$ \\
Resíduos & $12 \mathrm{t}$ & $23.400 \mathrm{Mcal}$ & $34,88 \%$ \\
\hline
\end{tabular}

Segundo Ripoli (1991), citando Zulaf et al. (1985) ${ }^{1}$, os Poderes Caloríficos Superior (PCS) e Inferior (PCI) médios, da palha de cana-de-açúcar (folhas secas) para diversas variedades e regiões do Estado de São Paulo são os mostrados na Tabela 5.

Tabela 5. Poderes Caloríficos Superior e Inferior do palhiço, segundo Zulaf et al (1985)

\begin{tabular}{|c|c|c|c|c|c|}
\hline Região & Variedades & Umidade (\%) & $\mathrm{H}(\%)$ & 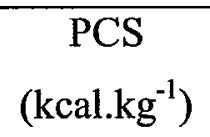 & 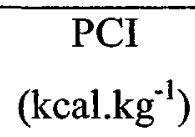 \\
\hline Bauru & SP70-1143 & 21,3 & 5,0 & 4315 & 3073 \\
\hline Piracicaba & NA5679 & 18,6 & 3,4 & 3979 & 2992 \\
\hline Araraquara & NA5679 & 9,1 & 4,0 & 4181 & 3563 \\
\hline Rib. Preto & SP70-1143 & 8,0 & 4,0 & 4096 & 3534 \\
\hline Campinas & CP5122 & 11,3 & 4,0 & 4098 & 3389 \\
\hline
\end{tabular}

$\mathrm{H}=$ hidrogênio elementar

Estimaram o potencial enegético dos resíduos de colheita de canaviais brasileiros, sem queima prévia, concluindo que, com as queimadas, desperdiça-se $87,72.10^{12} \mathrm{kcal}^{-a n o^{-1}}$ de energia, o que equivale ao abastecimento do pais por 63 dias com petróleo e uma economia de divisas da ordem de US\$1,464 bilhões.

\footnotetext{
${ }^{1}$ ZULAF, W. E. et al. Calculo preliminar da energia liberada na queima dos canaviais brasileiros. $\mathbb{N}$ : Simpósio sobre queima de palha de canaviais, 2, Araraquara, 1985, p. 1-7.
} 
Molina Jr et al. (1991), estudando métodos de recolhimento de palhiço de colheita manual de cana-de-açúcar, na variedade SP706163, no município de Piracicaba - SP, determinaram um Índice de Palhiço de 0,34 com Poder Calorífico Superior de $4.538,8$ kcal. $\mathrm{kg}^{-1}$, Poder calorífico Inferior de 4.200,2 kcal. $\mathrm{kg}^{-1}$ e Poder Calorífico Útil de $2.341,4 \mathrm{kcal} . \mathrm{kg}^{-1}$. Para o canavial estudado com produtividade agrícola determinada em 79,52 tha ${ }^{-1}$, a sua energia potencial bruta foi estimada na forma de álcool de 23.921 Mcal. ha ${ }^{-1}$, em bagaço de $35.591 \mathrm{Mcal}^{\text {ha }}{ }^{-1}$ e em palhiço de $62.679 \mathrm{Mcal}^{\text {. ha }}{ }^{-1}$.

Ripoli et al. (1997) determinaram o quanto de energia disponível existe no material remanescente (ponteiros, folhas verdes e palhas) de colheita mecanizada, em canaviais com queima (CQ) e sem queima prévia (CC). As análises laboratoriais e as determinações por equações forneceram as seguintes quantidades médias de palhiço remanescente e seus correspondentes valores energéticos em PCS e PCI: palhiço remanescente $\left(\right.$ t.ha ${ }^{-1}$ ): 13,51 (CC-1), 8,09 (CQ-I) e 24,32(CC-II), 10,25(CQ-II), tais massas apresentaram respectivamente os PCS - $\left(\right.$ Mcal.t $\left.^{-1}\right)$ de 4.365 (CC-I), 4.430 (CQ-I) e 4.460 (CC-II), 4.485 (CQ-II). Para o PCI em (Mcal.t ${ }^{-1}$ ) de 2.148 (CC-I), 2.185 (CQ-I) e 2.316 (CC-II), 2.216 (CQ-II), para o PCI.ha ${ }^{-1}$, resultaram valores médios de: 58.989Mcal.ha ${ }^{-1}=$ CC- SP711406; 35.843Mcal.ha ${ }^{-1}=$ CQ-SP711406; 113.313Mcal.ha ${ }^{-1}$

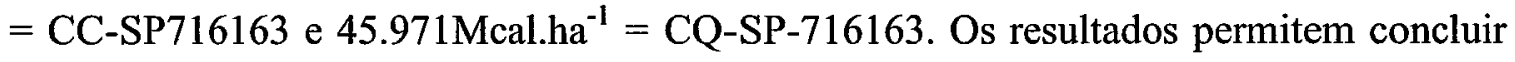
que a quantidade de energia disponível no palhiço nos tratamentos sem queima prévia, eqüivale a 0,76 equivalentes barris de petróleo (EBP). ha ${ }^{-1}$, desperdiçada nos canaviais, contendo as variedades estudadas.

Furlani Neto et al. (1997) determinaram que o potencial energético total de resíduo é em função da variedade de cana-de-açúcar utilizada, não dependendo de ser cana crua ou queimada. Os autores cincluíram com base no índice total de energia que a queima do canavial promoveu uma perda energética de 39,2\% para a variedade SP711406 e de 59,4\% para as SP71-6363, conforme resultados obtidos na Tabela 6. 
Tabela 6. Determinação da energia contida no palhiço, segundo Furlani Neto et al. (1997)

\begin{tabular}{cccccc}
\hline Variedades & Tipos & $\begin{array}{c}\text { Resíduos } \\
(\mathrm{t})\end{array}$ & $\begin{array}{c}\text { PCS } \\
\left(\mathrm{Mcal}^{-1}\right)\end{array}$ & $\begin{array}{c}\text { Energia } \\
\left(\mathrm{Mcal}^{-1} \mathrm{ha}^{-1}\right)\end{array}$ & $\begin{array}{c}\text { Índice total } \\
\text { Energia (\%) }\end{array}$ \\
\hline SP71-1406 & Cana crua & 13.514 & 4.365 & $58.998,6$ & 100 \\
SP71-1406 & Cana queimada & 8.091 & 4.430 & $35.843,1$ & 60,8 \\
SP71-6363 & Cana crua & 24.316 & 4.660 & $113.312,5$ & 100 \\
SP71-6363 & Cana queimada & 10.250 & 4.485 & $45.971,2$ & 40,6 \\
\hline
\end{tabular}

Ripoli et al. (2000) desenvolveram uma equação matemática (1), que fornece uma estimativa do número de pessoas que podem ser atendidas por essa energia elétrica, proveniente do bagaço e do palhiço de cana-de-açúcar e da palha de arroz.

$$
\mathrm{Pd}=(\mathrm{Pu} . \alpha . \text { Ac } . \mathrm{Qt} . \mathrm{Ef}) /(1314 . \mathrm{Cd})
$$

onde:

- Pd = estimativa do número de pessoas que podem se beneficiar com a energia elétrica oriunda do palhiço de cana-de-açúcar e da palha de arroz.

- $\mathrm{Pu}\left(\mathrm{MJ} \cdot \mathrm{Mg}^{-1}\right)=$ Poder Calorífico Útil do palhiço à umidade "U".

$-\alpha(\%)=$ quantidade de palhiço que será utilizada para a produção de energia elétrica.

- Ac $\left(\right.$ ha.ano $\left.{ }^{-1}\right)=$ área colhida, por ano, com o intuito de produção de energia, através do palhiço.

- Qt $\left(\mathrm{Mg}_{\mathrm{h}} \mathrm{ha}^{-1}\right)$ = quantidade de palhiço no campo após a colheita da cana-deaçúcar.

- Ef $(\%)=$ eficiência de conversão do processo.

- Cd $\left(\mathrm{kWh} \cdot \mathrm{d}^{-1}\right)=$ média de consumo diário por pessoa de baixa renda, conforme padrão CPFL.

A Usina da Barra (2001) estava transportando cerca de 55 cargas de 6 toneladas de palhiço de cana-de-açúcar, com a finalidade de geração de energia, por dia, mas para a próxima safra, a meta era atingir 220.000 toneladas dessa matéria-prima. Para atingir a capacidade atual da Usina que é de 36.000 tonelada de cana por dia, cuja fibra é de cerca 
de $12,50 \%$ na cana e a quantidade de bagaço gerado é de $9720 \mathrm{t}$, a adição de palha representa, hoje, $3,4 \%$ do bagaço. O poder calorífico inferior da palha determinado foi de $3200 \mathrm{kcal} . \mathrm{kg}^{-1}$ com $14 \%$ de umidade, ou seja, 1,8 vezes o poder calorífico inferior do bagaço de cana, com $50 \%$ de umidade, que é de $1790 \mathrm{kcal} . \mathrm{kg}^{-1}$. Devido à baixa densidade, a palha queima em suspensão, melhorando as condições de eficiência das caldeiras. Deve-se ressaltar que o poder calorífico da palha e do bagaço, nas mesmas condições de umidade, é equivalente, em função da composição dos combustíveis. $\mathrm{O}$ custo dessa operação é de cerca de US\$10 por tonelada (US\$ 5 pela terceirização, US\$ 3 pelo transporte e US\$ 2 envolvidos em outras operações). O teor de terra determinado foi de $0,6 \%$.

O Cenbio (2002b) cita que o carvão vegetal é produzido a partir da lenha pelo processo de carbonização ou pirólise. O Brasil é o maior produtor mundial desse insumo energético. O Poder Calorífico Inferior médio do carvão é de 7.365 kcal. $\mathrm{kg}^{-1}(30,8$ MJ.kg ${ }^{-1}$ ). O teor de material volátil varia de 20 a $35 \%$, o carbono fixo varia de 65 a $80 \%$ e as cinzas (material inorgânico), de 1 a 3\%. Além disso, é importante notar que o rendimento em massa do carvão vegetal, em relação à lenha seca enfornada, é de, aproximadamente, $25 \%$ nos fornos de alvenaria e a recuperação do licor pirolenhoso pode chegar a $50 \%$ em massa da lenha, sendo o restante gases.

\subsection{Desempenho operacional de enfardamento de palhiço de cana-de-açúcar}

Segundo Mialhe (1974), denomina-se desempenho operacional um complexo conjunto de informações que definem, em termos quali-quantitativos, os atributos da maquinaria agrícola, quando executa operações sob determinadas condições de trabalho. As informações necessárias podem ser agrupadas, levando-se em consideração as características operacionais referentes à qualidade e à quantidade de trabalho desenvolvido pela máquina, sob determinadas condições de trabalho; as características dinâmicas que consideram a potência requerida para o acionamento e a velocidade de trabalho da máquina e, por fim, as características de manejo que focalizam os aspectos relacionados com as regulagens, a manutenção, as reparações e a estabilidade. Para 
máquinas e implementos agrícolas, a capacidade operacional é a quantidade de trabalho que são capazes de executar na unidade de tempo, constituindo-se em uma medida da intensidade do trabalho desenvolvido, na execução de operações agrícolas.

A Usina Central Romana, na República Dominicana, conforme Lopez (1987), estudou o recolhimento de palhiço de cana-de-açúcar com vistas à produção de energia elétrica. O trabalho foi executado por picadoras de forragem convencionais, sendo o palhiço transportado até a via férrea por carretas. Os resultados médios de desempenho do sistema são mostrados na Tabela 7.

Tabela 7. Desempenho operacional do sistema, Lopez (1987)

\begin{tabular}{lcc}
\hline Resíduo & Recolhido. ano & \\
Resíduo & Recolhido. ha & $25.700 \mathrm{t}$ \\
Tonelada cana & t colhida. residuo $^{-1}$ & $11,8 \mathrm{t}$ \\
Dias & Trabalhados. safra & 4,1 \\
Resíduos & Recolhido. dia & 136 \\
Recolhedoras utilizadas & - & $190 \mathrm{t}$ \\
Capacidade efetiva & recolhimento & 5 \\
Capacidade efetiva & enleiramento & $5,7 \mathrm{t.h}^{-1}$ \\
Eficiência de campo & - & $7 \mathrm{th}^{-1}$ \\
\hline
\end{tabular}

$\mathrm{O}$ autor relata ainda que, para o palhiço existente no campo, foi determinado a quantidade de suas massas específicas em $14 \mathrm{t} \mathrm{ha}^{-1}$, a eficiência de recolhimento foi de $83 \%$, com $30 \%$ de umidade, operada por diversos tipos de máquinas, são mostrados na Tabela 8.

Tabela 8. Densidades das diferentes máquinas utilizadas no sistema, Lopez (1985)

\begin{tabular}{ll}
\hline Picado & $120 \mathrm{~kg} \cdot \mathrm{m}^{-3}$ \\
Fardos retangulares & $225 \mathrm{~kg} \cdot \mathrm{m}^{-3}$ \\
Fardos cilíndricos & $170 \mathrm{~kg} \cdot \mathrm{m}^{-3}$ \\
Briquetado $(10 \%$ de umidade) & $630 \mathrm{~kg} \cdot \mathrm{m}^{-3}$ \\
\hline
\end{tabular}

Howe \& Sreesangkon (1990), na Tailândia fizeram um trabalho experimental, a partir do qual apresentam informações de desempenho de enfardadoras cilíndricas e retangulares. Os resultados são apresentados na Tabela 9. 
Tabela 9. Desempenhos operacionais das enfardadoras ensaiadas, Howe \& Sreesangkon (1990)

\begin{tabular}{|c|c|c|}
\hline \multirow[t]{2}{*}{ Variáveis } & \multicolumn{2}{|c|}{ Enfardadoras de Fardos } \\
\hline & Cilíndricos & Prismáticos \\
\hline Cap. Efetiva (ha. $\mathrm{h}^{-1}$ ) & 0,29 & 0,22 \\
\hline Cap. Efetiva (t. $\left.\mathrm{h}^{-1}\right)$ & 2,49 & 2,21 \\
\hline Cap. Operacional $\left(\right.$ ha. $\left.h^{-1}\right)$ & 0,24 & 0,10 \\
\hline Cap. Operacional $\left(\mathrm{t} . \mathrm{h}^{-1}\right)$ & 1,45 & 1,04 \\
\hline Massas médias . fardos ${ }^{-1}(\mathrm{~kg})$ & 371 & 16,04 \\
\hline Densidades $\left(\mathrm{kg} \cdot \mathrm{m}^{-3}\right)$ & 146,9 & 99,6 \\
\hline Resíduos recolhidos (t.hat $)$ & 8,63 & 10,06 \\
\hline Recolhimentos (\%) & 71 & 78 \\
\hline
\end{tabular}

As enfardadoras operaram em áreas cuja quantidade média de palhiço existente era de 12,62 t.ha ${ }^{-1}$ e 12,44 t.ha ${ }^{-1}$. Para o transporte, utilizaram-se de dois caminhões, que levaram cargas médias de 2,09 t e 4,44 t por viagem, respectivamente.

A Copersucar (1998), iniciou um estudo para avaliar a viabilidade de se recolher o palhiço após a colheita mecanizada da cana crua. A idéia foi testar algumas enfardadoras e determinar seu desempenho. A necessidade de modificações, ou de desenvolvimento de outro equipamento para o recolhimento de palhiço, seria avaliada após os testes. Com o início do programa GEF, tais informações foram importantes para a seleção da enfardadora a utilizar nos testes do programa. A Tabela 10 apresenta um resumo dos testes de enfardamento de palhiço, realizados com as enfardadoras Sode JS90, Semeato ROL-1518 e New Holland NH-570. Na Tabela 11, a primeira e a segunda enfardadoras são de fardos cilíndricos e a terceira, de fardos retangulares. 
Tabela 10. Parte dos resultados obtidos pela Copersucar (1991)

\begin{tabular}{lcccc}
\hline Enfardadoras & Tipos de Fardo & $\begin{array}{c}\text { Sistemas de } \\
\text { Enfardamento }\end{array}$ & Enleiramento & $\begin{array}{c}\text { Capacidade } \\
\left(\text { t.h }^{-1}\right)\end{array}$ \\
\hline Sode JS-90 & Cilíndrico & Rolos & Sim & 1,8 \\
& Fixos & Não & 2,0 \\
Semeato & Cilíndrico & Correias & Sim & 2,7 \\
ROL-1518 & Grande & Tencionadas & Não & 1,0 \\
New Holland & Retangular & Prensa & Sim & 9,0 \\
NH-570 & Pequeno & & Não & 3,0 \\
\hline
\end{tabular}

Tabela 11. Valores médios obtidos no estudo da Copersucar (1991)

\begin{tabular}{ccccc}
\hline Enfardadoras & Enleiramento & $\begin{array}{c}\text { Pesos médios } \\
\text { dos fardos } \\
\text { (kgf) }\end{array}$ & $\begin{array}{c}\text { Densidades } \\
\text { dos fardos } \\
\left({\mathrm{kg} . \mathrm{m}^{-3}}^{-}\right)\end{array}$ & $\begin{array}{c}\text { Quantidade de } \\
\text { terra nos fardos } \\
(\%)\end{array}$ \\
\hline JS-90 & Sim & 105,8 & 118,0 & 5,6 \\
JS-90 & Não & 119,3 & 129,3 & 2,8 \\
ROL-1518 & Sim & 285,4 & 94,7 & 6,2 \\
ROL-1518 & Não & 260,0 & 107,5 & 2,3 \\
NH-570 & Sim & 15,0 & 112,0 & - \\
NH-570 & Não & - & - & - \\
\hline
\end{tabular}

Molina Jr. (1991a) estudou o recolhimento do palhiço de cana-de-açúcar por meio de uma enfardadora de fardos cilíndricos e encontrou uma massa específica média dos fardos de 189,64 kg.m ${ }^{-3}$, com uma massa média de 164,93 kg e um índice médio de terra de $3,17 \%$.

Molina Jr. et al. (1991b) estudaram o recolhimento de resíduo de colheita manual de cana-de-açúcar, onde obtiveram 0,61 ha.h $h^{-1}$ e $2,98 \mathrm{t}$. $\mathrm{h}^{-1}$ com uma enfardadora cilíndrica, conseguindo fardos com massa específica média de $184,06 \mathrm{~kg} \cdot \mathrm{m}^{-3}$, índice de terra de $3,15 \%$ e perdas de enfardamento (palhiço não recolhido) da ordem de $72,28 \%$. 
Molina Jr. et al. (1995) avaliaram os aspectos econômicos e operacionais de uma enfardadora de forragem cilíndrica, no enfardamento de palhiço de cana-de-açúcar sem queima prévia, visando o seu aproveitamento como combustível, conjuntamente com o bagaço, queimado nas fornalhas das caldeiras das unidades sucroalcooleiras. Concluíram que o poder calorífico do resíduo é equivalente ao do bagaço. $\mathrm{O}$ ensaio foi feito sob duas condições de campo: área A - primeiro corte e a área B - segundo corte. Os resultados obtidos, tanto do resíduo como dos desempenhos operacionais, são apresentados nas Tabelas 12, 13 e 14.

Tabela 12. Palhiço: Poderes Caloríficos Superior (PCS); Inferior (PCI) e Útil (PCU), kcal.kg-1; massa existente no campo após colheita (MRU), em t.ha ${ }^{-1}$; umidade percentual (U) e potencial energético (PER), em Mcal. ha ${ }^{-1}$, Molina Jr. et al. (1995)

\begin{tabular}{cccc}
\hline & \multicolumn{3}{c}{ Áreas } \\
Variáveis & A & B & Média \\
\hline PCS & $4405,6 \pm 652,2$ & $4236,7 \pm 1023,1$ & $4321,2 \pm 797,0$ \\
PCI & $4067,1 \pm 652,3$ & $3898,1 \pm 1023,1$ & $3982,6 \pm 797,0$ \\
PCU & $2970,2 \pm 1342,6$ & $3012,6 \pm 1063,1$ & $2991, \pm 1096,1$ \\
MRU & $12,71 \pm 4,48$ & $12,78 \pm 5,44$ & $12,55 \pm 4,524$ \\
U & $26,3 \pm 26,1$ & $21,9 \pm 14,4$ & $24,1 \pm 22,4$ \\
PER & $37921,0 \pm 22351,2$ & $36874,6 \pm 15317,1$ & $37397,8 \pm 17365,4$ \\
\hline
\end{tabular}

Tabela 13. Massa dos fardos (Mfa) em kg; massa específica fardos (Dfa), em $\mathrm{kg} . \mathrm{m}^{-3}$; massa de palhiço enfardado (MEU), em t.ha ${ }^{-1}$, e teor de terra nos fardos (IM), em percentagem, Molina Jr. et al. (1995)

\begin{tabular}{cccc}
\hline Variáveis & A & B & Média \\
\hline Mfa & $160,3 \pm 43,1$ & $169,6 \pm 36,7$ & $164,9 \pm 37,4$ \\
Dfa & $183,8 \pm 67,6$ & $195,5 \pm 43,6$ & $189,6 \pm 52,9$ \\
MEU & $4,6 \pm 4,0$ & $4,0 \pm 1,1$ & $4,3 \pm 2,7$ \\
IM & $3,4 \pm 3,3$ & $3,1 \pm 1,1$ & $3,2 \pm 2,6$ \\
\hline
\end{tabular}


Tabela 14. Consumo de combustivel da fonte de potência (CCh), em L.h ${ }^{-1}$; desempenho operacional do conjunto (CCT e CCA) em t.h ${ }^{-1}$ e t.ha ${ }^{-1}$; energia consumida pela fonte de potência na forma de combustível (ECE), em Mcal.ha ${ }^{-1}$; equivalente em energia no palhiço enfardado (EMR), em Mcal.ha ${ }^{-1}$, Molina Jr. et al. (1995)

\begin{tabular}{cccc}
\hline Variáveis & A & B & Média \\
\hline CCh & $4,3 \pm 0,9$ & $4,4 \pm 1,7$ & $4,3 \pm 1,2$ \\
CCT & $1,26 \pm 0,9$ & $0,96 \pm 0,3$ & $1,11 \pm 0,7$ \\
CCA & $0,28 \pm 0,08$ & $0,24 \pm 0,04$ & $0,26 \pm 0,07$ \\
ECE & $135,8 \pm 51,1$ & $162,2 \pm 60,3$ & $149,0 \pm 57,9$ \\
EMR & $13728,5 \pm 14441,9$ & $12009,8 \pm 3945,1$ & $12869,1 \pm 9659,06$ \\
\hline
\end{tabular}

Trabalhando com material remanescente de colheita sem queima prévia (palhiço), Ripoli (1991), enleirando e carregando à granel em carreta, obteve massa específica de transporte para as variedades estudadas SP70-1143 $=141,94 \mathrm{~kg} \cdot \mathrm{m}^{-3}$ e para a variedade NA $5679=104,63 \mathrm{~kg} \cdot \mathrm{m}^{-3}$. A Tabela 15, apresenta os desempenhos operacionais médios encontrados pelo autor.

Tabela 15. Desempenhos médios da operação de enleiramento, Ripoli (1991)

\begin{tabular}{|c|c|c|}
\hline \multirow[t]{2}{*}{ Operações } & \multicolumn{2}{|c|}{ Variedades } \\
\hline & SP70-1143 & NA5679 \\
\hline \multicolumn{3}{|l|}{ Enleiramento } \\
\hline Efetivo (ha. $\left.h^{-1}\right)$ & 1,67 & 1,79 \\
\hline Operacional $\left(\right.$ ha. $\left.h^{-1}\right)$ & 1,40 & 1,38 \\
\hline Consumo de combustível (L.h h $\left.^{-1}\right)$ & 8,37 & 7,62 \\
\hline Consumo de combustível (L.t ${ }^{-1}$ ) & 0,40 & 0,40 \\
\hline
\end{tabular}




\section{MATERIAL E MÉTODOS}

\subsection{Material}

\subsubsection{Condições de campo}

Os ensaios de campo foram realizados em área comercial do GRUPO COSAN Costa Pinto, município de Piracicaba, SP, cujas coordenadas geográficas da área central ao talhão apresenta as seguintes características geográficas, Latitude: $22^{\circ} 40^{\prime} 30^{\prime \prime}$ SUL, Longitude: $47^{\circ} 36^{\prime} 38^{\prime \prime}$ 'Oeste e Altitude de $605 \mathrm{~m}$.

\subsubsection{Variedade de cana-de-açúcar}

Palhiço resultante da colheita em cana crua, da variedade RB825336, plantada em espaçamento de $1,4 \mathrm{~m}$, em $3^{\circ}$ corte, com 11 meses de idade e que apresentou uma produtividade média de colmos de 78 t.ha $^{-1}$.

\subsubsection{Máquinas autopropelidas}

Fontes utilizados os seguintes equipamentos com fontes primárias de potência:

- Trator New Holland ${ }^{\circledR} 4$ X2, modelo TM 120, potência nominal 120CV a 2200 rpm;

- Carregadora convencional de cana Motocana ${ }^{\circledR}$;

- Caminhão de carga seca . 


\subsubsection{Ancinho enleirador}

Ancinho enleirador do tipo molinete cilíndrico oblíquo (Figura 1), marca New Holand $^{\circledR * 2}$, modelo 256, com as especificações técnicas conforme catalogo no anexo :

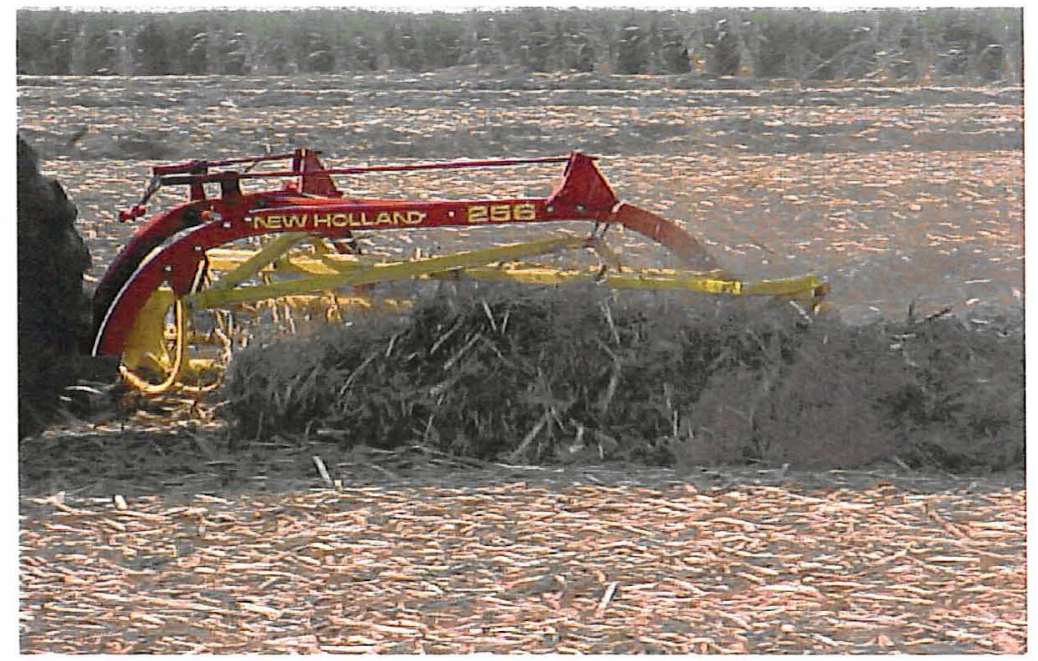

Figura 1 - Ancinho enleirador em operação

- Largura do ancinho: 2,6 m;

- Largura total: 3,1 m;

- Altura total: $1,3 \mathrm{~m}$;

- Comprimento total: $1,3 \mathrm{~m}$;

- Velocidade média de operação do ensaio: de $8,6 \mathrm{~km} \cdot \mathrm{h}^{-1}$;

- Peso: 358 kgf sem pneus;

- Barras de dentes de aço alto carbono;

- Número de dentes: 90 dentes;

- Acionamento por roda de terra.

* Marcas convencionais citadas neste trabalho não significam indicação ou preferência do autor. 


\subsubsection{Enfardadora cilíndrica}

Enfardadora cilíndrica, da marca New Holland, modelo 658, com as seguintes especificações técnicas:

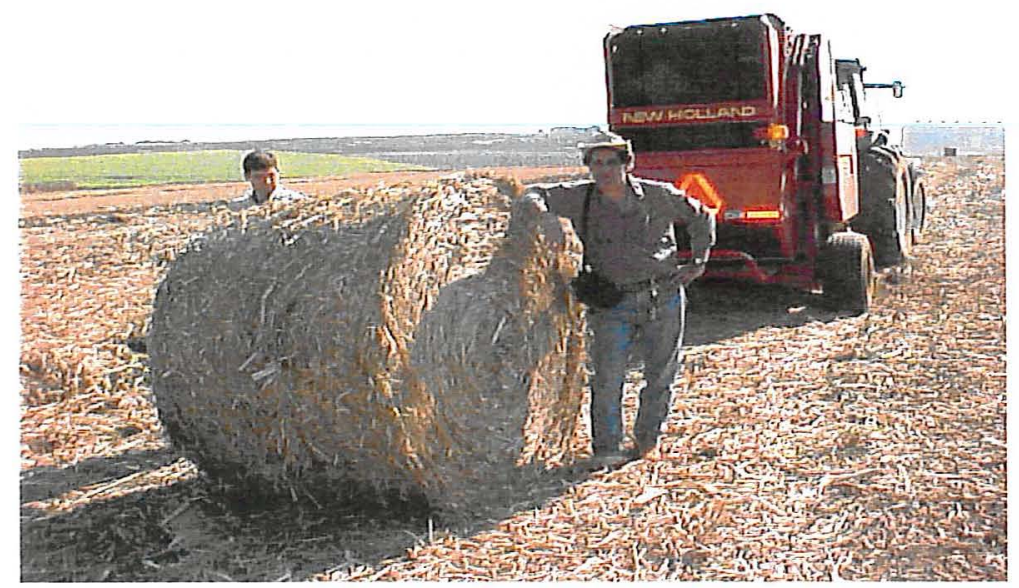

Figura 2 - Enfardadora Cilíndrica New Holland, modelo 658 e fardo produzido

- Potência exigida na tomada de potência: $75 \mathrm{HP}(56 \mathrm{~kW})$;

- Rotação da árvore da TDP: 540 rpm;

- Recolhedor com largura efetiva de 1,94m;

- Sistema de amarração;

- Tipo de barbante: sisal ou polipropileno;

Dimensões:

- Comprimento total de 4,32m;

- Altura total de 2,87m;

- Largura total de 2,39m;

- Peso de $2.452 \mathrm{~kg}$. 


\subsection{Instrumentos para determinações ponderais, dimensionais e volumétricas}

- Célula de carga marca KIOWA ${ }^{\circledR}$ de capacidade de carga de $1.000 \mathrm{~kg}$ e capacidade de leitura de $10^{-1} \mathrm{~kg}$, com Microprocessador PC da marca SODMEX ${ }^{\circledR}$ com saída analógica de 0 a $10 \mathrm{~V}$ (corrente contínua), e saída digital $\mathrm{R} 5232$ alimentação de 85 a 264V (corrente alternada);

- Balança de plataforma, para caminhões com capacidade de carga de $30.000 \mathrm{~kg}$ e capacidade de leitura de $5 \mathrm{~kg}$, do GRUPO COSAN - Costa Pinto;

Para as determinações de tempo de percurso das máquinas foi utilizado um cronômetro digital da marca $\mathrm{CASIO}^{\circledR}$, com capacidade de leitura de $10^{-2} \mathrm{~s}$.

Para as determinações de consumo de combustível foram utilizadas duas buretas graduadas com capacidades máximas de $500 \mathrm{~mL}$ e $1000 \mathrm{~mL}$ e capacidade de leitura de $1 \mathrm{~mL}$.

Para as determinações das dimensões dos fardos, das distâncias de enfardamento e demarcação de áreas foram utilizadas trenas metálicas com $5 \mathrm{~m}$ da marca ESLON e capacidade de leitura de $10^{-2} \mathrm{~m}$ e trenas de fibra de vidro da marca ESLON de $50 \mathrm{~m}$, com capacidade de leitura de $10^{-2} \mathrm{~m}$. Para as estimativas da quantidade de palhiço existente nas áreas de estudo, usou-se um gabarito quadrado de ferro de área de $1 \mathrm{~m}^{2}$ de fabricação própria.

\subsection{Material de laboratório}

\subsubsection{Instrumentos para determinação de umidade}

Foram utilizados os instrumentos:

- Sonda padrão de amostragem de matéria-prima, marca CODISTIL $^{\circledR}$, do laboratório de análise tecnológica da Usina Costa Pinto;

- Estufa marca FANEM, modelo 315SE;

- Balança analítica, marca METTLER ${ }^{\circledR}$, modelo P11, capacidade de carga $5 \mathrm{~kg}$ e capacidade de leitura de $10^{-2} \mathrm{~g}$. 


\subsubsection{Instrumentos para determinação do poder calorifico e matéria estranha mineral}

Os equipamentos utilizados para as determinações de poder calorífico do palhiço

"in natura" e para as determinações de terra residual nas cinzas foram:

- Balança analítica, marca METTLER ${ }^{\circledR}$, modelo H10, capacidade de carga de $160 \mathrm{~g}$ e capacidade de leitura de $10^{-4} \mathrm{~g}$;

- Bomba calorimétrica, marca INCOMAP ${ }^{\circledR}$, modelo D-127;

- Moinho de facas;

- Cadinhos de porcelana;

- Mufla, marca FORMITEC ${ }^{\circledR}$, com temperatura máxima de $1000^{\circ} \mathrm{C}$;

- Dessecadores;

- Tenazes;

- Peneira convencional da construção civil;

- Bateria de peneiras de análise granulométrica de solo.

\subsubsection{Outros materiais}

- Tripé metálico de suporte para a célula de carga;

- Sacos plásticos, de papel e de aniagem;

- Facões;

- Lonas plástica. 


\subsection{Métodos}

\subsubsection{Caracterização do tipo de solo e umidade}

Foram coletadas cinco amostras de solo na profundidade de 0 a $0,05 \mathrm{~m}$, casualizadamente na área de estudo e acondicionadas em recipientes de alumínio, vedadas hermeticamente com fita adesiva, para a determinação em laboratório, da umidade e granulometria.

\subsubsection{Caracterização do palhiço}

A caracterização do palhiço remanescente da colheita mecanizada, na área de estudo foi realizada com base no método de Molina Jr (1991) onde, antes da operação de enfardamento, o material foi amostrado com o auxílio do gabarito quadrado de ferro, com 15 repetições sobre a área. O material encontrado no interior do gabarito foi recolhido (Figura 3A), ensacado, identificado e vedado (Figura 3B), para posteriores determinações de peso e da composição vegetal e mineral. De cada repetição tomou-se uma sub-amostra para posterior determinação do poder calorífico e da umidade.
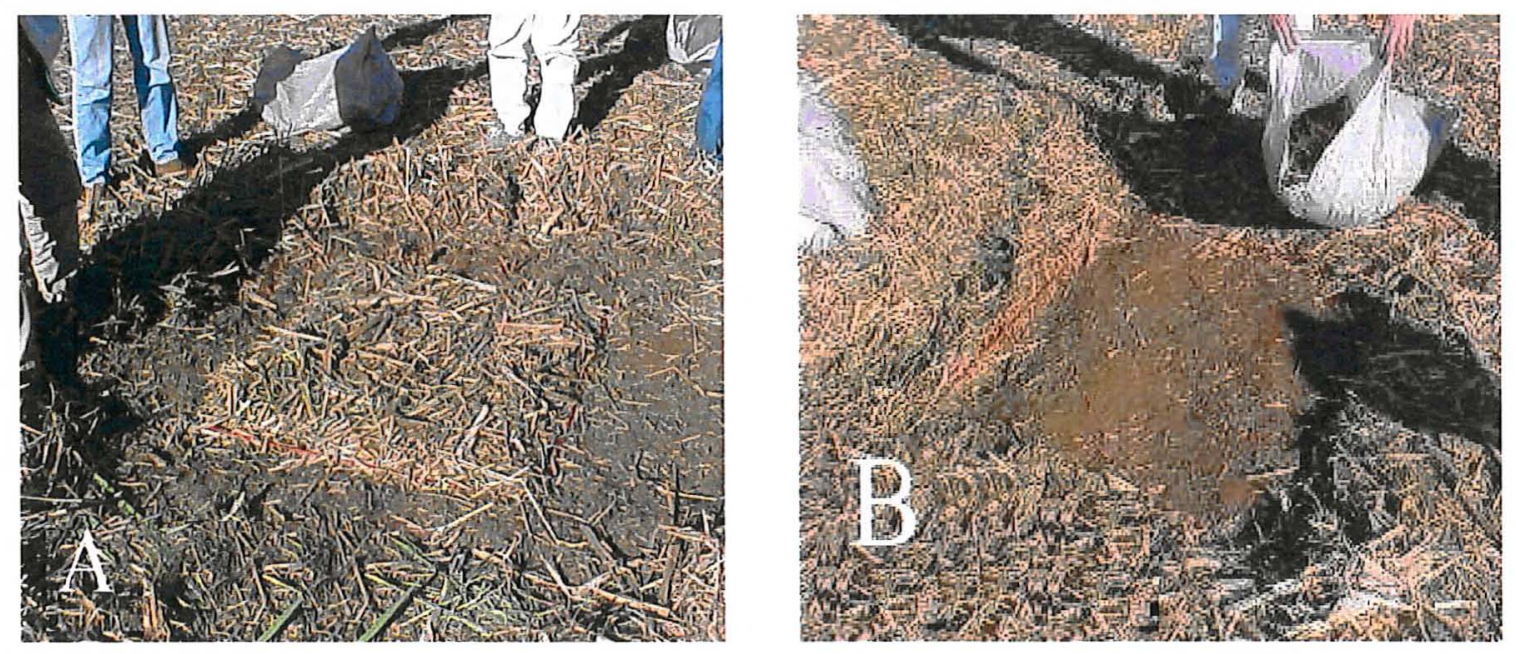

Figura 3 - Palhiço no campo após colheita mecanizada (A), Palhiço ensacado (B) 


\subsubsection{Preparação dos tratamentos}

A preparação dos tratamentos foi realizada utilizando-se do ancinho enleirador para o enleiramento do palhiço existente na área experimental. A regulagem do equipamento foi efetuada pelo técnico da Case-New Holland ${ }^{\circledR}(\mathrm{CNH})$, e a mesma regulagem foi mantida para os dois tratamentos aplicado. O primeiro tratamento foi caracterizado por um enleiramento simples do palhiço, que constou de uma única passada do ancinho enleirador. O segundo tratamento foi caracterizado por um enleiramento duplo, que constou de duas passadas adjacentes do ancinho enleirador, uma em sentido contrário a outra, de modo a conseguir uma única leira de palhiço.

\subsubsection{Determinação dos tempos e movimentos}

Para as determinações de tempos e movimentos nos enleiramentos simples e duplo, considerou-se os ciclos operativos unidirecionais fechados. Portanto, o deslocamento da máquina não considera manobras de cabeceiras, desde o início do trajeto até o final do mesmo.

\subsubsection{Determinação do consumo de combustível no enleiramento}

Em cada início de tratamento, com o trator nivelado, o tanque de combustível era completado com o combustível, até uma marca preestabelecida em seu bocal. Ao final de cada tratamento, utilizando-se de buretas graduadas, completava-se o volume de combustível no reservatório da máquina, até a marca inicial preestabelecida, obtendo-se a quantidade consumida de combustível em cada tratamento.

\subsubsection{Determinação das áreas enleiradas}

Nos dois tipos de tratamentos (simples e duplo), as determinações dos comprimentos das áreas enleiradas foram feitas através de trenas, ao longo do 
comprimento da área, seguindo o mesmo trajeto executado pelo ancinho enleirador. As larguras das áreas, nos dois tratamentos, foram determinadas por trenas, medindo-se as distâncias perpendiculares ao trajeto do equipamento, ao acaso, em 4 repetições. No tratamento simples a área enleirada foi determinada com a média das medidas de largura anotadas casualizadamente ao longo da faixa enleirada, medindo-se a largura equivalente a 6 leiras, por repetição, e determinando-se a largura média efetiva de cada uma das faixas enleiradas. No tratamento duplo a área enleirada foi determinada com a média das medidas de largura ao longo da faixa, das duas passadas, medindo-se a largura equivalente a 7 leiras, por repetição, e determinando-se a largura média efetiva de cada uma das faixas enleiradas.

\subsection{Codificação dos tratamentos}

O presente estudo é parte integrante de um projeto complexo de trabalho que se utilizou de diversos equipamentos. Para caracterizar os tratamentos estabeleceu-se uma codificação específica, cabendo à enfardadora que produziu fardos cilíndricos o código CR. Para completar a identificação de cada tratamento estabeleceu-se o número de cada fardo, e as letras "S" para enleiramento simples e "D" para enleiramento duplo. Por exemplo: CR1S1 - enfardadora cilíndrica, fardo 1, tratamento simples, amostra 1

CR2D2 - enfardadora cilíndrica, fardo 2, tratamento duplo, amostra 2.

\subsubsection{Enfardamento}

Para a operação de enfardamento, foi considerado como uma repetição, o recolhimento de uma dada quantidade de palhiço enleirado sobre o terreno e depositado na forma de um fardo. Levou-se em conta a distância percorrida entre fardos, o tempo gasto, o combustível consumido e a correspondente área coberta resultante do tipo de enleiramento efetuado. As larguras das áreas utilizadas foram descritas no item 3.4.6.

O comprimento das áreas nos dois tratamentos foi determinado considerando-se

a distancia entre o inicio e o final de operação de enfardamento, medindo-se a distancia 
desde o inicio da operação até o primeiro fardo e as distancias entre fardos. Assim, em função dos tratamentos, foram obtidas diferentes quantidades de fardos por tratamento. Do total de fardos, 4 fardos de cada tratamento foram escolhidos, ao acaso, para retiradas de amostras, para análises laboratoriais.

\subsubsection{Determinação do consumo de combustível no enfardamento}

No inicio dos tratamentos, com o trator e a enfardadora nivelados, o tanque foi completado de combustível conforme descrito no item 3.4.5. A quantidade de combustível consumida em cada repetição foi obtida dividindo-se, proporcionalmente, o valor consumido no tratamento, pelas distâncias percorridas e correspondentes para a obtenção de cada fardo.

\subsubsection{Determinações dimensionais e ponderais dos fardos}

Os fardos foram medidos em seus diâmetros e larguras (Figura 4A) com o auxílio de uma trena. Pela célula de carga acoplada à garra de uma carregadora de cana-deaçúcar, foram determinadas as massas dos fardos (Figura 4B), visando a determinação de seus volumes e respectivas massas específicas.
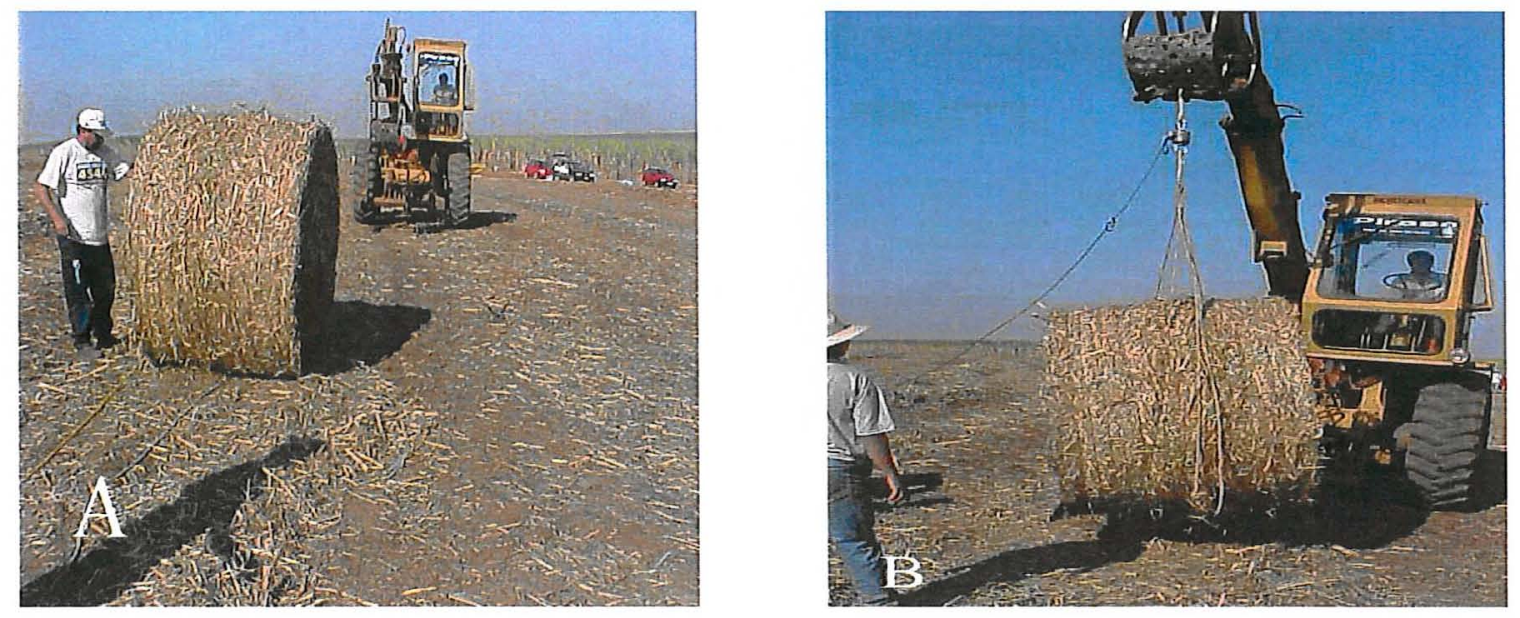

Figura 4-Medições dimensional (A), e ponderal (B) 


\subsubsection{Caracterização do palhiço amostrado após o enfardamento}

Os fardos foram carregados (Figura $5 \mathrm{~A}$ ) com o auxílio de uma carregadora de cana-de-açúcar e transportados (Figura 5B) para a Usina Costa Pinto para a retirada de duas amostras, por fardo, por meio da sonda do laboratório de análise tecnológica.
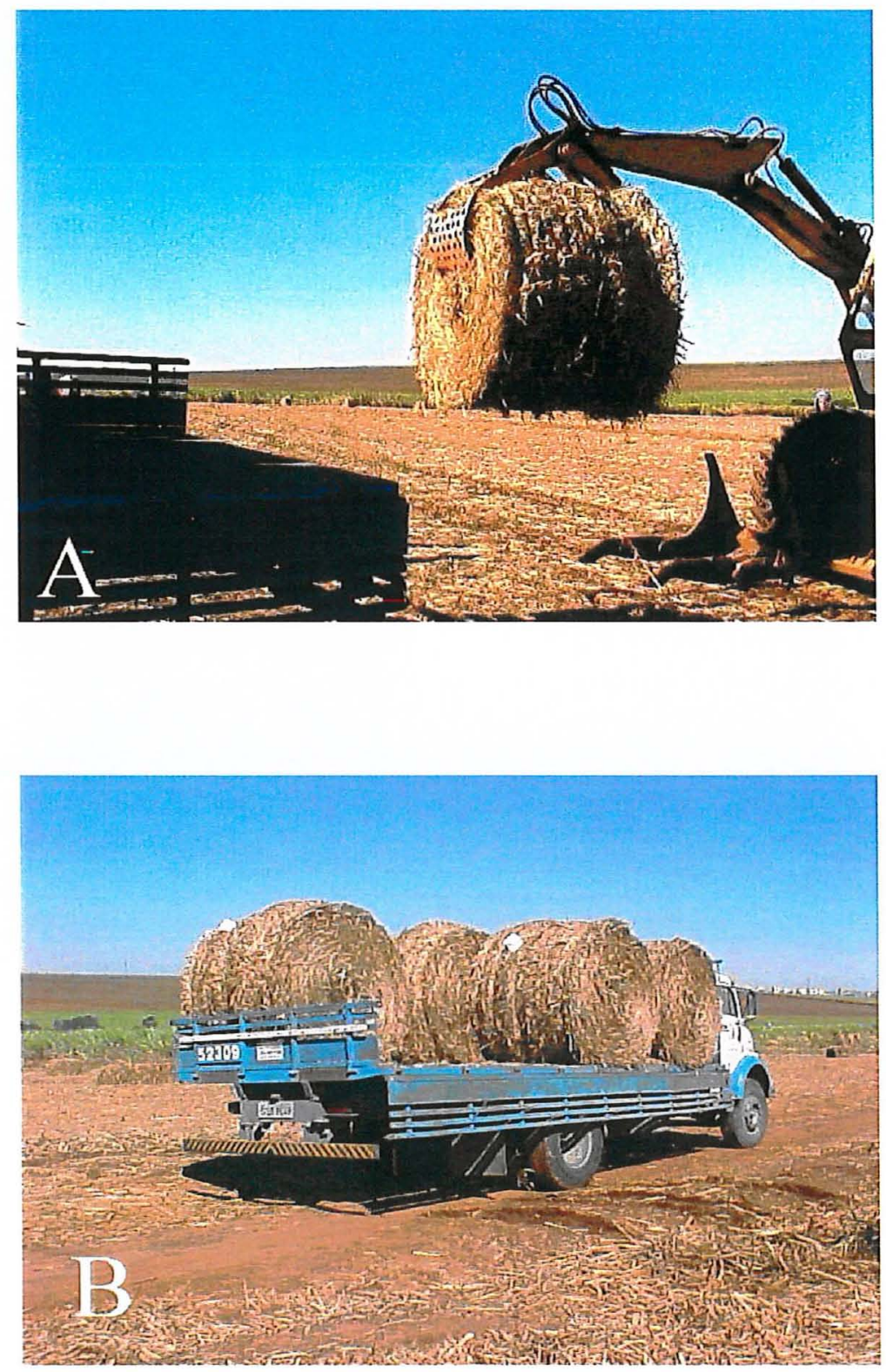

Figura 5 - Operações de carregamento (A) e transporte (B) de fardos 
O material de cada amostra obtido pela sonda (Figura 6A e 6B) foi ensacado, identificado (Figura 7), fechado hermeticamente e levado para o laboratório da ESALQ/USP, no Departamento de Engenharia Rural na área de máquinas agrícolas, da qual, duas sub-amostras foram coletadas para a determinação da umidade do palhiço. Seguindo o mesmo método de identificação dos fardos, as duas sub-amostras adquiridas levaram as mesmas especificações dos seus respectivos fardos.
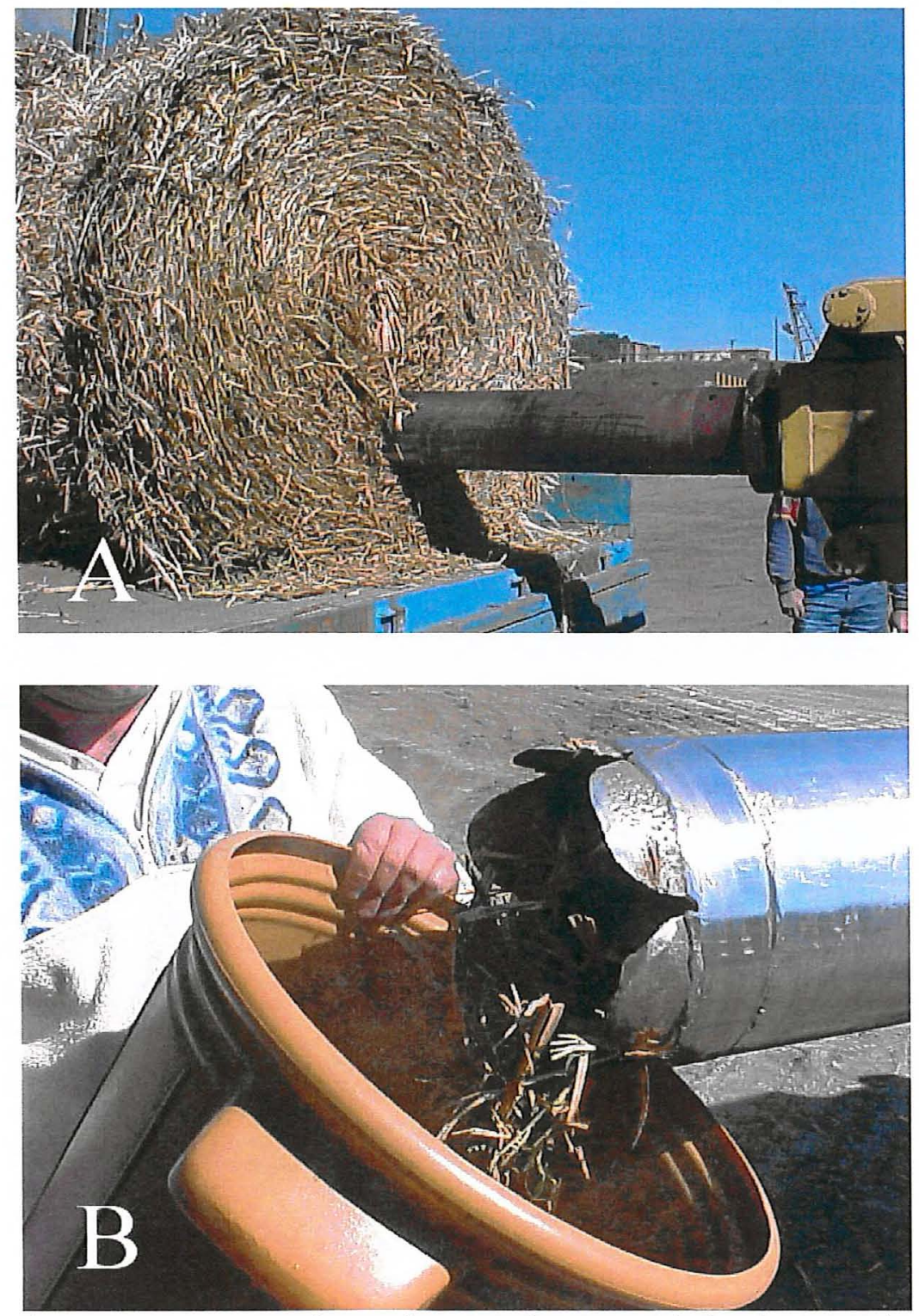

Figura 6 - Amostragem para determinação da quantidade de terra junto ao palhiço enfardado 


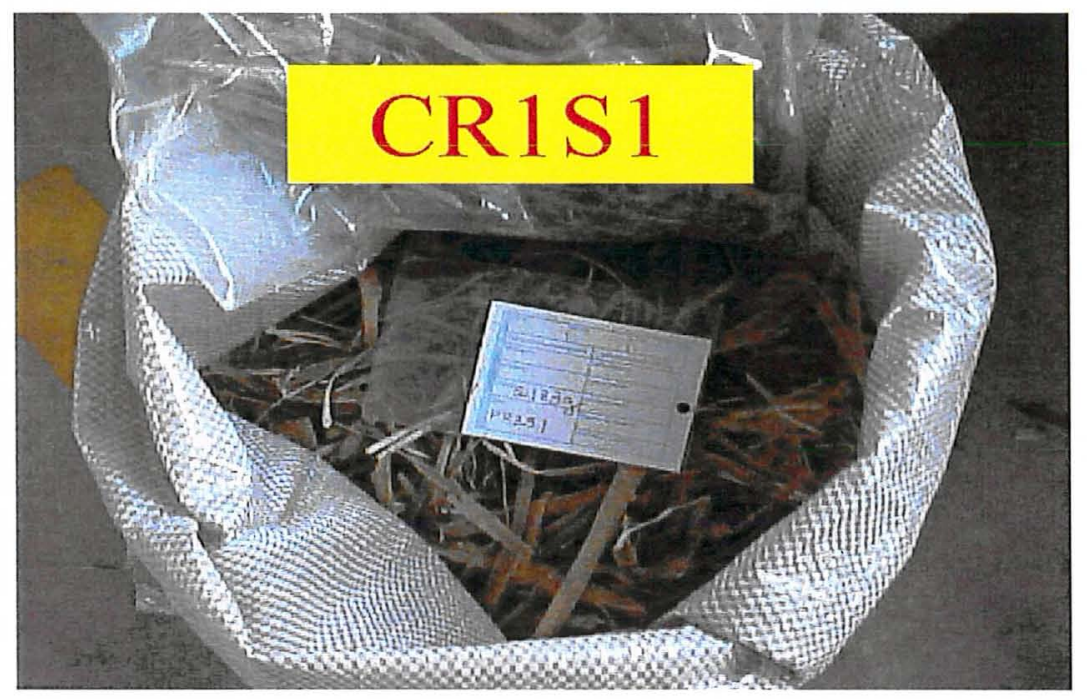

Figura 7 - Exemplo de amostra retirada por meio da sonda

\subsection{Determinações de laboratório}

\subsubsection{Caracterização do material antes do enfardamento}

As amostras de palhiço coletadas antes do enfardamento conforme item 3.4.2, tiveram suas massas determinadas através de uma célula de carga. Os constituintes das amostras foram separados manualmente sobre uma lona plástica em: folhas, ponteiros, frações de colmos e terra com particulados vegetais. As sub-amostras adquiridas foram identificadas e colocadas em sacos plásticos hermeticamente fechados e, posteriormente, efetuada a determinação de suas massas em uma balança analítica digital.

\subsubsection{Determinação da umidade antes do enfardamento}

As sub-amostras obtidas no item 3.5.4 foram separadas em duas partes distintas, a primeira para a determinação do poder calorífico superior e a segunda para a determinação da umidade do palhiço. A umidade (U\%) foi determinada em função do peso úmido do material, em percentagem. No passo seguinte as sub-amostras foram 
levadas para uma estufa por um período de 48 horas na temperatura de $105^{\circ} \mathrm{C}$. A seguir, o material foi retirado da estufa, pesado sua massa em base seca e obtendo-se a percentagem da umidade encontrada no palhiço antes do enfardamento.

\subsubsection{Determinação dos poderes caloríficos superior, inferior e útil}

Para determinar o poder calorífico superior (PCS) do palhiço, foi utilizada a norma NBR 8633 (ABNT 1984), que estabelece a determinação do poder calorífico do carvão vegetal, definido como o número de calor liberado pela combustão de uma unidade de massa de uma substância, em bomba calorimétrica, em atmosfera de oxigênio, a volume constante e sob condições especiais, de modo que toda a água proveniente da combustão esteja no estado líquido. Após a obtenção do poder calorífico superior das sub-amostras aplicou-se o método de Doat (1977), que fornece o poder calorífico inferior $(\mathrm{PCI})$, com base nas informações sobre a quantidade de hidrogênio do combustível, calor absorvido para vaporização da água, da proporção da água formada na combustão, conforme a equação 3 :

$$
P C I=P C S-\left(\frac{600.9 . H}{100}\right)
$$

onde:

$\mathrm{PCS}=$ poder calorífico superior $\left(\mathrm{kcal}_{\mathrm{kg}}{ }^{-1}\right)$;

$\mathrm{PCI}=$ poder calorífico inferior $\left(\mathrm{kcal} . \mathrm{kg}^{-1}\right)$;

$\mathrm{H}=$ teor de hidrogênio do material $\left(\mathrm{kcal} . \mathrm{kg}^{-1}\right)$.

600 = valor médio da energia absorvida por $\mathrm{kg}$ de água para atingir a temperatura de vaporização

9 = múltiplo do peso do hidrogênio no combustível, fornecendo o peso da água formada na combustão.

$\mathrm{O}$ autor propõe a transformação do poder calorífico inferior $(\mathrm{PCI})$ em poder calorífico útil (PCU), onde se considera a umidade do material, pela equação 4: 


$$
P C U=P C I \cdot\left[\frac{100-U}{100}\right]-6 . H
$$

onde:

PCU = poder calorífico útil $\left(\mathrm{kcal} . \mathrm{kg}^{-1}\right)$;

$\mathrm{U}=$ teor de umidade do material com base em peso úmido;

6 = fator de conversão referente à energia de evaporação da água de formação.

\subsection{Caracterização do material amostrado após o enfardamento}

\subsubsection{Determinação da umidade após o enfardamento}

As amostras obtidas pela sonda da usina foram transferidas para sacos de aniagem, de onde foram coletadas duas sub-amostras de cada amostra . O procedimento para a determinação da umidade foi o mesmo citado no item 3.6.2.

\subsubsection{Determinações ponderais de terra (amostras)}

\subsubsection{Terra não aderida ao palhiço}

As massas das 16 amostras obtidas por meio da sonda da usina conforme item 3.5.4 foram determinadas utilizando-se de uma célula de carga. As amostras pesadas foram peneiradas em peneira de malha de $2,5 \mathrm{~mm}$, o que permitiu a passagem de terra e de partículado vegetal. Este material foi pesado em uma balança analítica. Para a separação mais fina do material vegetal, o mesmo, foi passado através de uma bateria de análise granulométrica de solo, restando após a passagem pela peneira mais fina somente a terra e um particulado extremamente fino. Este material, por sua vez, foi pesado e as duas sub-amostras do mesmo fardo misturadas e homogeneizadas. $O$ material foi colocado em cadinhos tarados e queimados a $700^{\circ} \mathrm{C}$ e levados a estufa por 24 horas, para a eliminação da umidade. Os cadinhos com o material seco foram pesados em balança analítica e levados a mufla para serem queimados por 4 horas a uma temperatura de $700^{\circ} \mathrm{C}$. Os cadinhos foram retirados da mufla e colocados em um 
dissecador, para resfriamento e eliminação da umidade e posterior pesagem e determinação de material mineral mais as cinzas do material vegetal. A determinação por peneiramento, do material não aderido ao palhiço, é ilustrado conforme fluxograma da Figura 8.

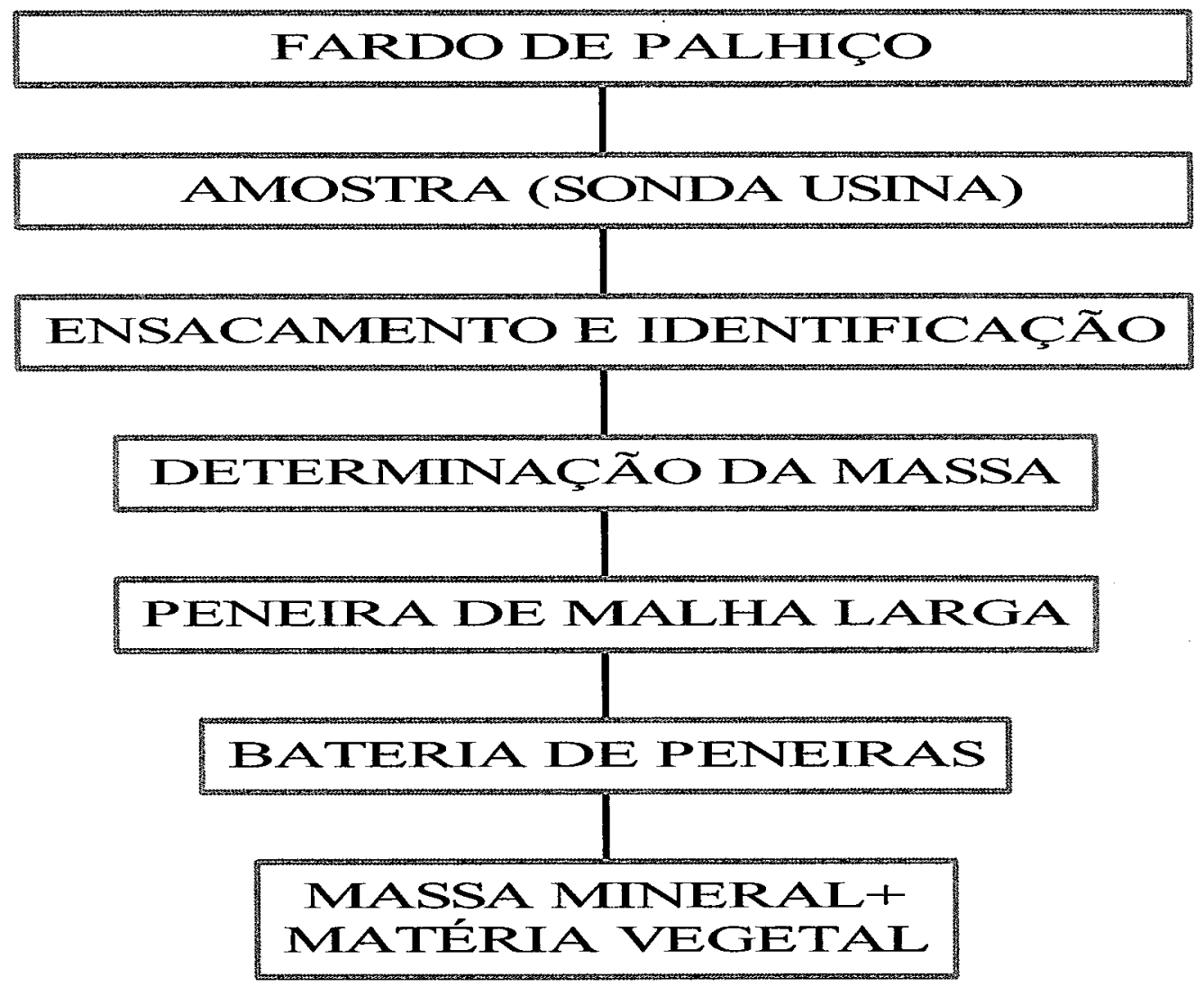

Figura 8 - Fluxograma da determinação, por peneiramento, de terra não aderida ao palhiço

\subsubsection{Terra aderida ao palhiço}

Duas sub-amostras (de cada amostra) do material que não passaram pela peneira de $2,5 \mathrm{~mm}$, foram retiradas para a determinação de terra aderida às folhas. Uma das subamostras de cada amostra foi lavada exaustivamente para eliminar o máximo possível de 
terra aderido às folhas e deixadas ao Sol para secagem. O passo seguinte foi a moagem das sub-amostras (lavadas e não lavadas) que foram reduzidas a pó. Os cadinhos foram previamente queimados a $700^{\circ} \mathrm{C}$, para a eliminação de resíduos. As sub-amostras foram colocadas em cadinhos e levadas a estufa por 24 horas para a eliminação da umidade para serem pesadas. Após isso os cadinhos foram levados a mufla a $700^{\circ} \mathrm{C}$ por 4 horas para obtenção de cinzas.

Na seqüência os cadinhos foram colocados no dissecador para o resfriamento e retirada da umidade existente e assim pesados. Obteve-se deste modo as percentagens de cinza do material vegetal e cinza do material vegetal mais terra. Para a determinação da percentagem de cinzas lavadas utilizou-se da equação (5):

$$
C P L \%=\left(\frac{P C L}{P P L}\right) \cdot 100
$$

onde:

CPL $(\%)=$ percentagem de cinza de palhiço lavado;

$\operatorname{PCL}(\mathrm{kg})=$ massa da cinza de palhiço lavado moído;

$\operatorname{PPL}(\mathrm{kg})=$ massa seca de palhiço lavado moído.

Para a determinação da porcentagem de cinza não lavada foi utilizada a equação (6):

$$
C P N L \%=\left(\frac{P C N L}{P P N L}\right) \cdot 100
$$

CPNL $(\%)=$ porcentagem de cinza de palhiço não lavado; PCNL (kg) = massa da cinza de palhiço não lavado moído; PPNL (kg) = massa seca de palhiço não lavado moído. 
Para a determinação da porcentagem do índice de terra, aderido às folhas, subtraiu-se a percentagem de cinza de palhiço lavado da percentagem de cinza de palhiço não lavado conforme a equação (7):

$$
I T \%=C P N L \%-C P L \%
$$

onde:

IT $(\%)=$ índice de terra do palhiço;

CPNL $(\%)=$ porcentagem de cinza de palhiço não lavado;

CPL $(\%)=$ porcentagem de cinza de palhiço lavado.

A Figura 9, ilustra o fluxograma da determinação da terra não aderida ao palhiço.

\subsubsection{Avaliação das capacidades efetivas}

A metodologia adotada para determinar a capacidade efetiva da enfardadora, foi a preconizada por Mialhe (1974). No estudo da enfardadora foi realizada uma adequação da metodologia para se obter as variáveis desejadas. São: fardo.(t $)^{-1}$, consumo de combustível.(fardo $)^{-1}$ e quantidade de energia consumida. $(\mathrm{t})^{-1}$, de material enfardado.

\subsubsection{Balanço energético}

Determinou-se o balanço energético para os dois enleiramentos: simples e duplo e para enfardamento mais enleiramento. A metodologia de cálculo do balanço energético foi proposta por RIPOLI (1991), para o cálculo do balanço energético no recolhimento de palhiço com base no consumo de combustível e potencial energético do palhiço, por meio da equação (8):

onde:

$$
B E=\left(1-\frac{C C}{P E P}\right) \cdot 100
$$


$\mathrm{BE}(\%)=$ Balanço energético;

$\mathrm{CC}\left(\mathrm{Mj} \cdot \mathrm{kg}^{-1}\right)=$ Consumo de combustível;

PEP $\left(\mathrm{Mj} . \mathrm{kg}^{-1}\right)=$ Potencial energético do palhiço.

\subsection{Análise estatística}

Neste estudo, cada fardo obtido representou uma repetição. Foram realizados dois tratamentos casualizadamente distribuídos dentro de uma área onde uma dada variedade de cana-de-açúcar foi colhida num mesmo dia. Do total de fardos obtidos, quatro de cada tratamento foram casualizadamente escolhidos para analise de terra. A analise estatística realizada considerou o experimento como inteiramente casualizado e comparou a diferença entre as médias para as variáveis obtidas por meio do teste $\mathrm{T}$ e os intervalos de confiança foram obtidos ao nível de $5 \%$ de significância, segundo Gomes (2000). Para os cálculos foi utilizado o programa $\mathrm{SAS}^{\circledR}$. 


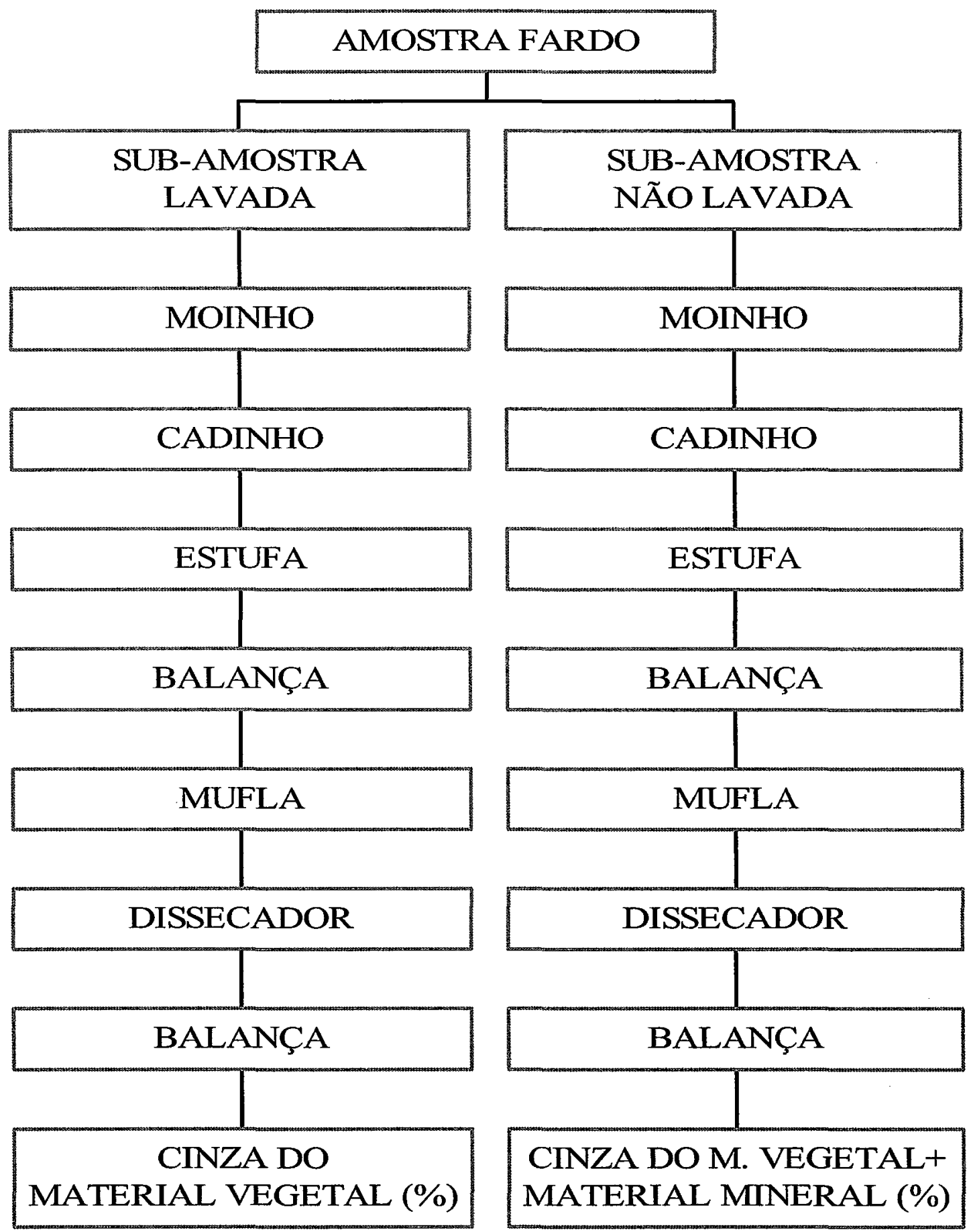

Figura 9 - Fluxograma da determinação da terra não aderida ao palhiço 


\section{RESULTADOS E DISCUSSÃO}

\subsection{Caracterização do solo}

A Tabela 16 mostra os valores obtidos e referentes aos dados de granulometria, umidade e tipo de solo no presente estudo e que foi classificado como Franco arenoso.

Tabela 16. Análise granulométrica, umidade e tipo de solo

\begin{tabular}{ccccc}
\hline Amostras & $\begin{array}{c}\text { Argila } \\
(\%)\end{array}$ & $\begin{array}{c}\text { Silte } \\
(\%)\end{array}$ & $\begin{array}{c}\text { Areia } \\
(\%)\end{array}$ & $\begin{array}{c}\text { Umidade } \\
(\%)\end{array}$ \\
\hline $28 \mathrm{P} 15$ & 10,78 & 18,61 & 70,61 & 10,44 \\
$01 \mathrm{P} 14$ & 12,41 & 17,74 & 69,95 & 11,78 \\
$25 \mathrm{P} 15$ & 8,66 & 21,74 & 69,6 & 10,78 \\
$18 \mathrm{P} 13$ & 14,69 & 18,22 & 67,09 & 10,52 \\
$05 \mathrm{P} 15$ & 16,14 & 17,72 & 66,14 & 14,33 \\
\hline
\end{tabular}

\subsection{Caracterização do Palhiço na matéria-prima}

A Tabela 17 ilustra os valores médios para os componentes do palhiço remanescente e seus constituintes, num canavial com produtividade média de colmos de 78 t.ha $^{-1}$. 
Tabela 17. Percentagens dos constituintes e da produtividade estimada do palhiço, antes da operação de enleiramento. IF = índice de folhas; IFc $=$ índice de frações de colmos; IPont = índice de ponteiros; $\mathrm{IM}=$ índice de matéria estranha total; $\mathrm{PE}=$ produtividade estimada

\begin{tabular}{lccccc}
\hline Repetições & $\begin{array}{c}\mathrm{IF} \\
(\%)\end{array}$ & $\begin{array}{c}\mathrm{IFc} \\
\mathbf{( \% )}\end{array}$ & $\begin{array}{c}\text { IPont } \\
(\%)\end{array}$ & $\begin{array}{c}\text { IM } \\
(\%)\end{array}$ & $\begin{array}{c}\text { PE } \\
(\text { t.ha }\end{array}$ \\
\hline Médias & 69,93 & 21,44 & 2,27 & 6,36 & 27,01 \\
DP & 3,66 & 4,67 & 1,44 & 4,31 & 8,8 \\
CV & 0,05 & 0,22 & 0,63 & 0,68 & 0,33 \\
IC & {$[68,08 ; 71,79]$} & {$[19,08 ; 23,81]$} & {$[1,54 ; 3,00]$} & {$[4,18 ; 8,24]$} & {$[22,55 ; 31,46]$} \\
\hline
\end{tabular}

Como se observa na Tabela 18, a produtividade média estimada de palhiço foi de 27,01 t.ha $^{-1}$ com um índice de palhiço de $34,63 \%$ em relação aos colmos industrializáveis na área estudada e uma umidade de $22,8 \%$ conforme a Figura 10 . A produtividade estimada de palhiço, em base seca foi de 20,33 t.ha ${ }^{-1}$ ou $26,06 \%$ em relação a produção de colmos industrializáveis. Este dado é confirmado por Ripoli et. al. (1990), que concluíram que o palhiço variou de 17 a $31 \%$ em seu peso, em comparação a percentagem de colmos industrializáveis. Ripoli et. al. (1991) obtiveram uma produção de 77,71 t.ha ${ }^{-1}$, com uma produtividade de palhiço de 21,61 t.ha ${ }^{-1}$ e com umidade de $46,11 \%$, representando um índice de palhiço de $28 \%$. Constatou-se pelas informações obtidas neste estudo, que os valores obtidos assemelham-se ao encontrado na bibliografia, tendo uma ligeira vantagem em relação a umidade apresentada. Esta diferença pode ter decorrido pelas variações climáticas na hora da coletada do material. Assim, os valores aqui obtidos de percentagem de palhiço estão dentro dos encontrados por estas duas citações. A Figura 10 ilustra os constituintes do palhiço remanescente amostrado. 


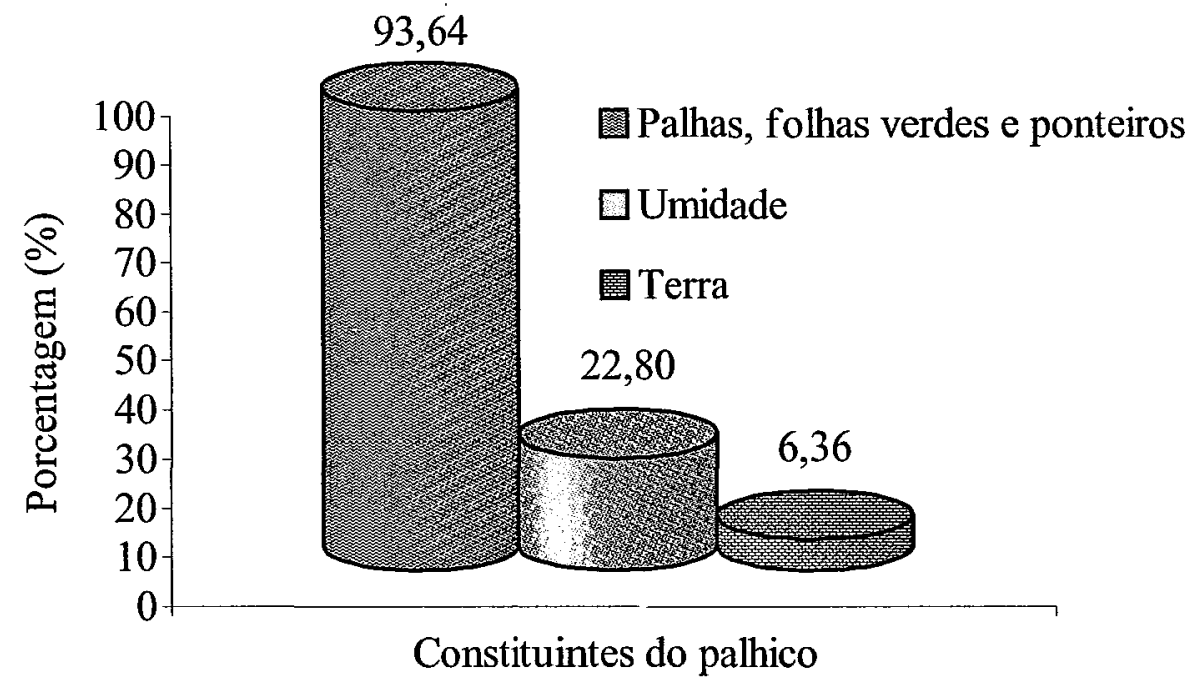

Figura 10 - Percentagem dos constituintes do palhiço amostrado

\subsection{Potencial energético}

A Tabela 18 apresenta os valores médios determinados dos poderes caloríficos e o valor médio do potencial energético do palhiço.

Tabela 18. Resultados de poderes calorificos e umidade do palhiço. $\mathrm{U}=$ umidade; $\mathrm{PCS}=$ poder calorífico superior; $\mathrm{PCI}=$ poder calorífico inferior; $\mathrm{PCU}=$ poder calorífico útil; PEP = potencial energético do palhiço; DP = desvio padrão; $\mathrm{CV}=$ coeficiente de variação; $\mathrm{IC}=$ intervalo de confiança

\begin{tabular}{|c|c|c|c|c|c|}
\hline Repetições & $\begin{array}{c}\text { Umidade } \\
(\%)\end{array}$ & $\begin{array}{c}\text { PCS } \\
\left(\mathrm{MJ} . \mathrm{kg}^{-1}\right)\end{array}$ & 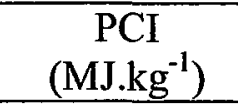 & $\begin{array}{c}\text { PCU } \\
\left({\left.\mathrm{MJ} . \mathrm{kg}^{-1}\right)}\right.\end{array}$ & $\begin{array}{c}\text { PEP } \\
\left(\text { GJ.ha }^{-1}\right)\end{array}$ \\
\hline Média & 20,76 & 18,43 & 17,01 & 13,32 & 494,88 \\
\hline DP & 4,53 & 1,12 & 1,12 & 1,18 & 157,19 \\
\hline $\mathrm{CV}$ & 21,84 & 6,06 & 6,56 & 8,88 & 31,76 \\
\hline IC & {$[18,47 ; 23,06]$} & {$[17,86 ; 18,99$} & {$[16,44 ; 17,57$} & {$[12,72 ; 13,92]$} & {$[415,33 ; 574,42$} \\
\hline
\end{tabular}

Com uma energia estimada de $280850 \mathrm{MJ}$ em uma produtividade de 60 t.ha $^{-1}$ citada por Ripoli \& Molina Jr. (1991) e comparando com a energia estimada de 380673

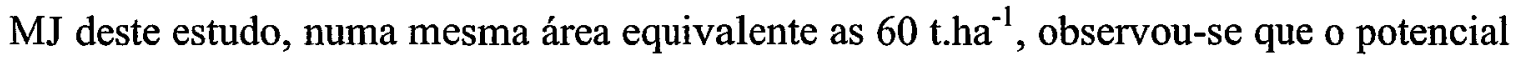
da área estudada é maior do que a citada pelos autores. 
Por meio dos valores encontrados por Ripoli (1991) na Tabela 3 e comparandoos com os valores do poder calorífico superior (PCS) e inferior (PCI) de $18,43 \mathrm{MJ}^{\mathrm{kg}} \mathrm{kg}^{-1} \mathrm{e}$ $17,01 \mathrm{MJ} \cdot \mathrm{kg}^{-1}$ com umidade de $22,8 \%$ do estudo, pode-se constatar que os valores são maiores do que os citados pelo autor.

Confrontando-se os valores apresentados por Ripoli (1998) e comparando-os com os valores obtidos neste estudo, observou-se que o valor do poder calorífico superior (PCS) de 18,43 MJ.kg-1 com umidade de 22,8\% do estudo é maior do que os obtidos pelo autor citado. Da mesma forma, o poder calorífico inferior $(\mathrm{PCI})$ de 17,01 MJ.kg-1 com umidade de 22,8\% deste estudo foram menores do que os citados pelo autor. $\mathrm{O}$ poder calorífico superior do resíduo estudado pode ser considerado em torno de $18,43 \mathrm{MJ} \cdot \mathrm{kg}^{-1}$, como média. O poder calorífico útil sofre grande influência do grau de umidade, sendo no caso de utilizá-lo como combustível, que se estude maneiras de reduzi-lo.

\subsection{Desempenho operacional do ancinho enleirador}

A Tabela 19, apresenta os resultados médios de desempenho operacional e eficiência energética referente aos enleiramentos simples e duplo, obtidos neste estudo. A análise da Tabela 20 mostra que todas as comparações das médias nos tratamentos simples e duplo diferiram significativamente ao nível de $1 \%$ através do teste de Tukey.

O enleiramento simples apresentou a maior capacidade efetiva (CE) neste estudo, sendo superior ao enleiramento duplo em $27,75 \%$. Os valores obtidos de capacidade efetiva (CE) deste trabalho quando comparados com as de Ripoli (1991), em relação a ordem de grandeza e os valores deste estudo, foram superiores aos determinados por esse autor: de 1,67 e 1,79 ha. $\mathrm{h}^{-1}$. O consumo médio de combustível por tonelada foram inferiores aos valores encontrados por Ripoli (1991) que foi de 0,40 L.t ${ }^{-1}$. 
Tabela 19. Resultados de desempenho operacional do ancinho enleirador. $\mathrm{CE}=$ capacidade efetiva; $\mathrm{CO}=$ capacidade operacional; $\mathrm{CCha}=$ consumo de combustivel por hectare; $\mathrm{CCt}=$ consumo de combustível por tonelada; $\mathrm{BE}=$ balanço energético; $\mathrm{DP}=$ Desvio padrão; $\mathrm{CV}=$ Coeficiente $\mathrm{de}$ variação; $\mathrm{IC}=$ Intervalo de confiança

\begin{tabular}{|c|c|c|}
\hline \multirow[b]{2}{*}{ Variáveis } & \multicolumn{2}{|c|}{ Tipos de Enleiramentos } \\
\hline & Simples & Duplos \\
\hline \multicolumn{3}{|l|}{$\operatorname{CE}\left(t . h^{-1}\right) *$} \\
\hline Média & 83,06 & 72,06 \\
\hline C.V. & 3,69 & 9,69 \\
\hline I.C. & {$[81,16 ; 84,96]$} & {$[68,53 ; 75,59]$} \\
\hline \multicolumn{3}{|l|}{$\operatorname{CO}\left(t_{.} h^{-1}\right) *$} \\
\hline Média & 74,36 & 66,29 \\
\hline C.V. & 3,69 & 9,69 \\
\hline I.C. & {$[72,06 ; 76,06]$} & {$[63,04 ; 69,54]$} \\
\hline \multicolumn{3}{|l|}{ CCha (L.há-1 $) *$} \\
\hline Média & 4,74 & 5,52 \\
\hline C.V. & 3,71 & 9,85 \\
\hline I.C. & {$[4,63 ; 4,85]$} & {$[5,25 ; 5,80]$} \\
\hline \multicolumn{3}{|l|}{$\operatorname{CCt}\left(\right.$ L.t $\left.^{-1}\right) *$} \\
\hline Média & 0,18 & 0,20 \\
\hline C.V. & 3,71 & 9,85 \\
\hline I.C. & {$[0,17 ; 0,18]$} & {$[0,19 ; 0,21]$} \\
\hline \multicolumn{3}{|l|}{ BE (\%) * } \\
\hline Média & 99,95 & 99,94 \\
\hline C.V. & 0,002 & 0,01 \\
\hline I.C. & {$[99,95 ; 99,95]$} & {$[99,94 ; 99,95]$} \\
\hline
\end{tabular}


Tabela 20. Desempenho operacional do ancinho enleirador em ha.h $\mathrm{h}^{-1} \mathrm{CE}=$ capacidade efetiva e $\mathrm{CO}=$ capacidade operacional

\begin{tabular}{lccc}
\hline & \multicolumn{2}{c}{ Enleiramentos } & \\
Variáveis & Simples & Duplo & Médio \\
\hline CE $\left(\right.$ ha. h $\left.^{-1}\right)$ & 3,07 & 2,67 & 2,91 \\
CO $\left(\right.$ ha. $\left.\mathrm{h}^{-1}\right)$ & 2,75 & 2,45 & 2,56 \\
\hline
\end{tabular}

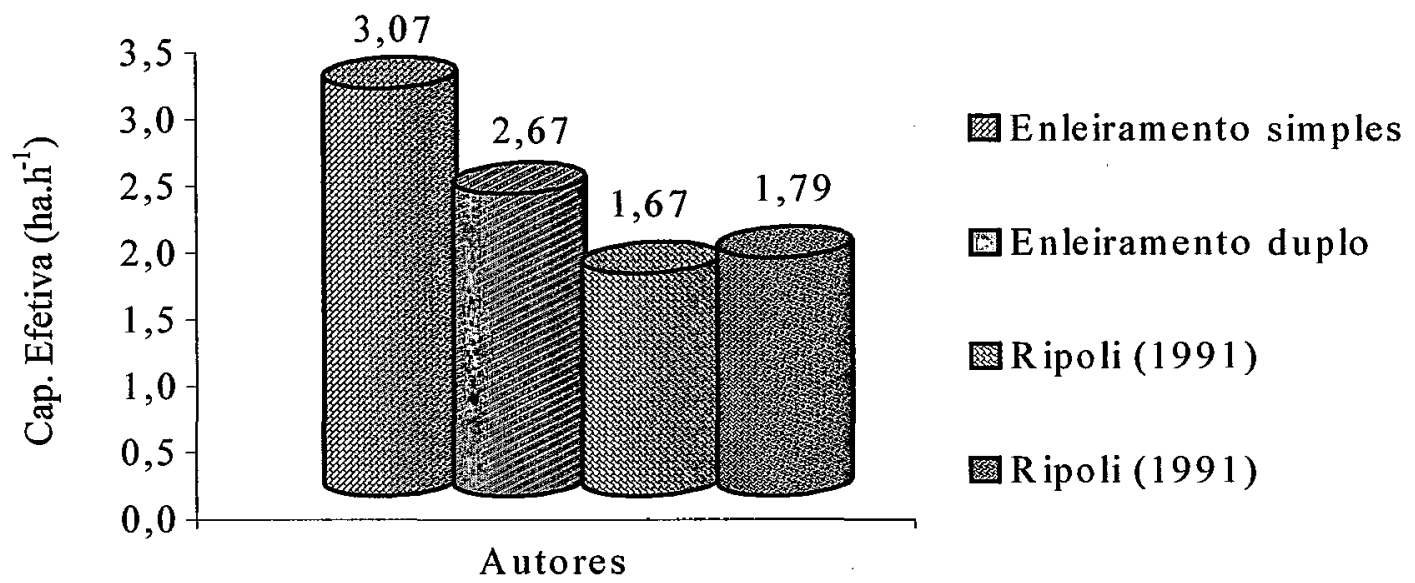

Figura 11 - Comparação de valores das capacidades efetivas obtidos neste estudo com os obtidos por Ripoli (1991)

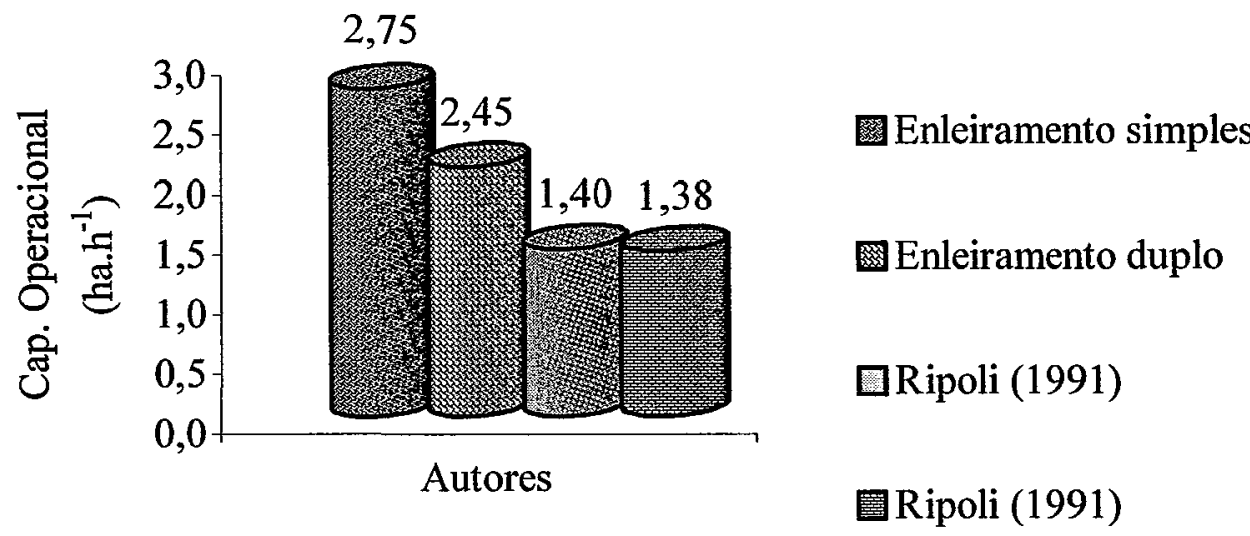

Figura 12 - Comparação dos valores das capacidades operacionais obtidos neste estudo com os obtidos por Ripoli (1991) 
Em relação ao consumo de combustível por tonelada $(\mathrm{CCt})$ os valores deste estudo foram menores que o obtido por Ripoli (1991) para as duas formas de enleiramento apresentadas neste estudo como mostrada na Figura 13.

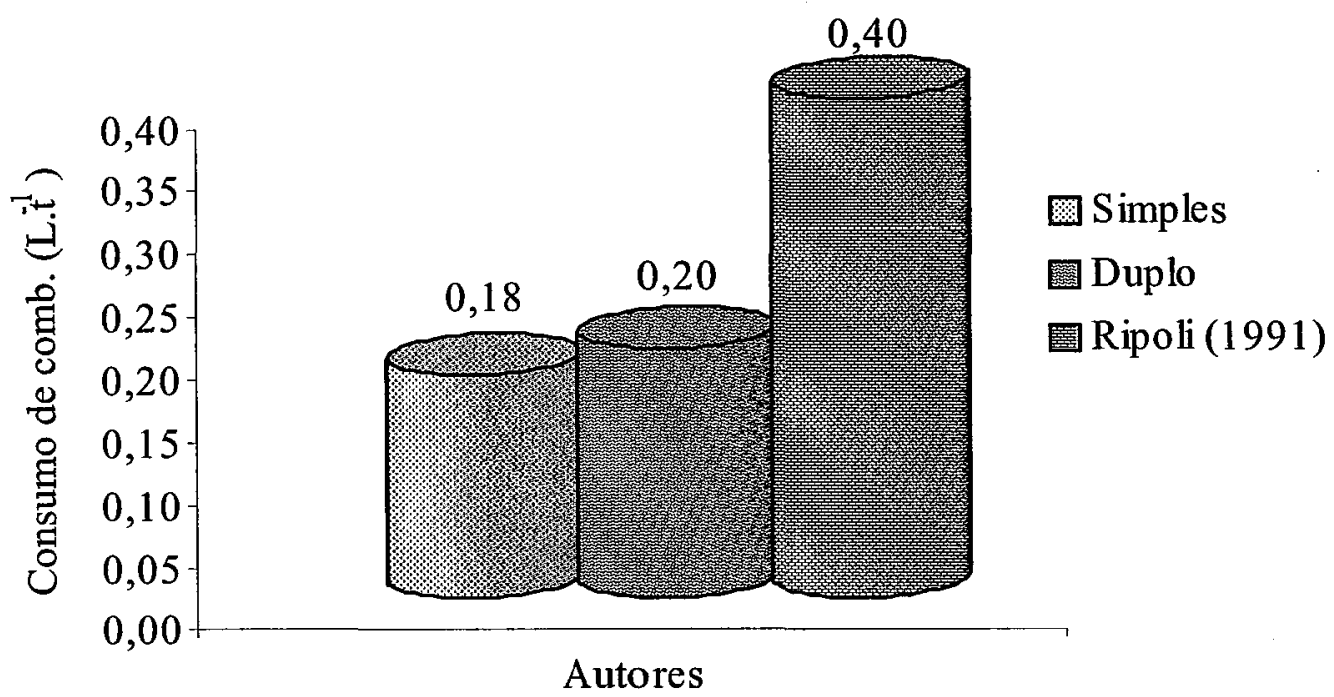

Figura 13 - Valores comparativos entre os obtidos no estudo e os encontrados por Ripoli (1991), para o consumo de combustível no enleiramento

As diferenças encontradas acima devem ser observadas somente quanto à ordem de grandeza e também com relação à metodologia e sistemas empregados distinitos que apresentam uma grande dependência das fontes de potência utilizadas e em condições de campo diferentes das deste trabalho.

\subsection{Desempenho operacional da enfardadora}

A Tabela 21 apresenta resultados médios das variáveis estudadas na quantificação das massas especificas dos fardos, capacidades efetivas, consumo de combustível por tonelada, eficiência energética no enleiramento, enfardamento e na soma das duas operações, além das comparações entre médias obtidas com a aplicação do teste de Tukey ao nível de $1 \%$ e $5 \%$ de significância. 
Tabela 21. Resultados de desempenho operacional da enfardadora. DF $=$ densidade do fardo; $\mathrm{CE}=$ capacidade efetiva; $\mathrm{CCt}=$ consumo de combustível por tonelada; $\mathrm{BE}=$ balanço energético do enfardamento; $\mathrm{BT}=$ balanço energético do enleiramento e enfardamento; MPenf = massa estimada de palhiço enfardado; $\mathrm{Mpr}=\mathrm{CV}=$ coeficiente de variação; $\mathrm{IC}=$ intervalo de confiança

\begin{tabular}{|c|c|c|}
\hline \multirow{2}{*}{ Variáveis } & \multicolumn{2}{|c|}{ Tipos de Enfardamentos } \\
\hline & Simples & Duplo \\
\hline \multicolumn{3}{|c|}{ DF $\left(\text { kg.m }^{-3}\right)^{* *}$} \\
\hline Média & 168,26 & 191,61 \\
\hline $\mathrm{CV}$ & 5,09 & 7,74 \\
\hline $\mathrm{IC}$ & {$[159,86 ; 176,66]$} & {$[177,09 ; 206,14]$} \\
\hline \multicolumn{3}{|c|}{$\operatorname{Cem}\left(\operatorname{t.h}^{-1}\right)^{* *}$} \\
\hline Média & 8,50 & 12,95 \\
\hline $\mathrm{CV}$ & 34,48 & 13,14 \\
\hline $\mathrm{IC}$ & {$[5,62 ; 11,37]$} & {$[11,28 ; 14,61]$} \\
\hline \multicolumn{3}{|c|}{ Cea $\left(\text { ha.h } h^{-1}\right)^{* *}$} \\
\hline Média & 1,03 & 1,16 \\
\hline CV & 4,24 & 7,90 \\
\hline $\mathrm{IC}$ & {$[0,99 ; 1,07]$} & {$[1,07 ; 1,25]$} \\
\hline \multicolumn{3}{|c|}{$\operatorname{CCt}\left(\text { L.t }^{-1}\right)^{*}$} \\
\hline Média & 0,64 & 0,43 \\
\hline $\mathrm{CV}$ & 4,35 & 4,67 \\
\hline $\mathrm{IC}$ & {$[0,61 ; 0,67]$} & {$[0,41 ; 0,45]$} \\
\hline \multicolumn{3}{|c|}{$\operatorname{MPenf}\left(\mathrm{t} \cdot \mathrm{ha}^{-1}\right)$} \\
\hline Média & 8,28 & 11,19 \\
\hline $\mathrm{CV}$ & 35,85 & 14,54 \\
\hline $\mathrm{IC}$ & {$[5,37 ; 11,16]$} & {$[9,59 ; 12,78]$} \\
\hline \multicolumn{3}{|c|}{$\operatorname{MPr}\left(\right.$ t.ha $\left.^{-1}\right)$} \\
\hline Média & 18,73 & 15,82 \\
\hline $\mathrm{CV}$ & 15,84 & 10,28 \\
\hline $\mathrm{IC}$ & {$[15,82 ; 21,64]$} & {$[14,22 ; 17,41]$} \\
\hline \multicolumn{3}{|l|}{ BE $(\%)^{*}$} \\
\hline Média & 99,979 & 99,962 \\
\hline $\mathrm{CV}$ & 0,001 & 0,002 \\
\hline $\mathrm{IC}$ & {$[99,978 ; 99,980]$} & {$[99,960 ; 99,964]$} \\
\hline \multicolumn{3}{|l|}{ BT $(\%)^{*}$} \\
\hline Média & 99,930 & 99,905 \\
\hline $\mathrm{CV}$ & 0,001 & 0,002 \\
\hline IC & {$[99,931 ; 99,929]$} & {$[99,903 ; 99,906]$} \\
\hline
\end{tabular}

$*=1 \%$ de significância; $* *=5 \%$ de significância. 
A bibliografia apresenta as massas específicas médias de fardos cilíndricos de palhiço com suas umidades conforme diversos autores.

\begin{tabular}{lcc}
\hline & Densidades $\left(\mathrm{kg}^{-3}\right)$ & Umidades (\%) \\
\hline Lopez (1987) & 170,00 & 30 \\
Howe \& Sreesagkon (1990) & 146,90 & 9,77 \\
Molina Jr et al. (1991b) & 184,06 & 43 \\
Copersucar (1991) - Sode JS90 & 129,30 & - \\
Copersucar (1991) - Sode JS90 & 118,00 & - \\
Copersucar (1991) - Semeato ROL - 1518 & 94,70 & - \\
Copersucar (1991) - Semeato ROL - 1518 & 107,50 & - \\
Molina Jr (1991a) e Molina Jr et al. (1995) & 189,60 & 24,10 \\
\hline
\end{tabular}

Os ensaios realizados por Molina Jr. (1991a) e Molina Jr. et al. (1991b), foram feitos com o mesmo modelo de enfardadora. Embora para Molina Jr. et al. (1991b) o resíduo de colheita de cana-de-açúcar fosse resultado de colheita manual, operação de enleiramento e sua umidade bem superior ao valor encontrado por Molina Jr. (1991a), observou-se que a densidade foi praticamente a mesma nos dois estudos, sugerindo que tanto a umidade não influenciou na compactação do resíduo enfardado, quanto se o resíduo foi enleirado ou não. E neste estudo o valor da massa específica apresentada na Tabela 22, foi superior aos valores encontrados por outras citações, no enleiramento duplo e, para o enleiramento simples o valor aproximou-se dos citados por Lopez (1987), sugerindo que a densidade do fardo é influenciada pelo tipo do mecanismo de formação do fardo utilizado em cada tipo de enfardadora. A partir das comparações verificou-se que para a massa específica dos fardos (DF), as médias diferiram entre si a $5 \%$ de significância através do teste de Tukey. A Figura 14 mostra os valores de massa específica dos fardos deste trabalho e os valores encontrados na bibliografia.

A vantagem de obtenção de fardos com massas específicas maiores é a economia do volume ocupado no transporte e no armazenamento, a facilidade de manejo e maior resistências às intempéries. 
聿Enf. Duplo

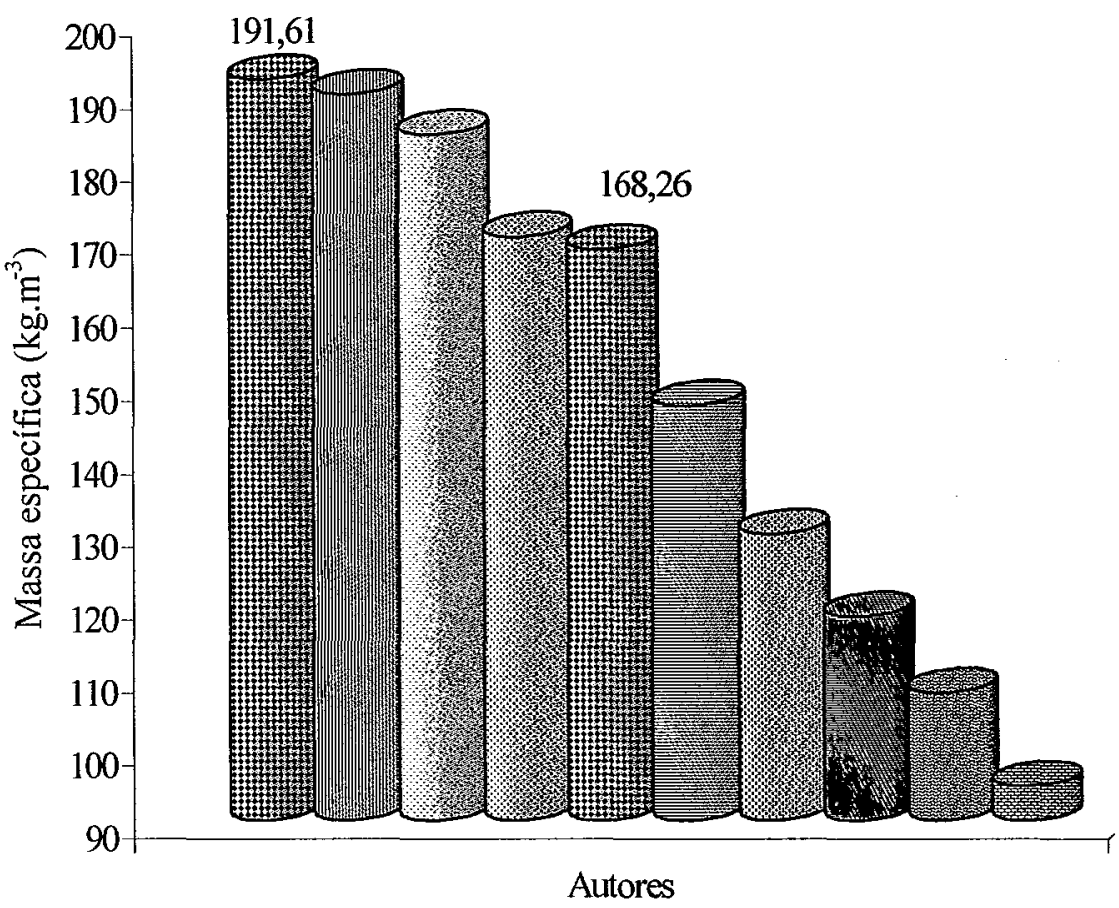

$\square$ Molina Jr et al. (1991a)

Molina Jr et al. (1991b)

웇 Lopez(1987)

Enf. Simples

圈H\&S(1990)

.

圆 Sode JS90 (1991)

Semeato ROL1518(1991)

Semeato ROL 1518(1991)

Figura 14 - Massa específica dos fardos cilíndricos de palhiço deste estudo e os citados na bibliografia, para diferentes marcas de enfardadoras

Para a capacidade efetiva $\operatorname{CEm}\left(\mathrm{t} \cdot \mathrm{h}^{-1}\right)$ a comparação foi significativamente diferente para os dois tratamentos ao nível de 5\%. Para a capacidade efetiva CEa (ha. $\mathrm{h}^{-1}$ ) as médias diferiram significativamente para os dois tratamentos ao nível de $5 \%$. Os valores determinados neste estudo para às capacidades efetivas indicaram que o tratamento duplo proporcionou uma maior capacidade efetiva à operação de enfardamento. Fato confirmado pela COPERSUCAR (1998) que em ensaios de enfardamento, com e sem enleiramentos, obteve maiores capacidades para os tratamentos com enleiramento. Os resultados de capacidades efetivas da COPERSUCAR (1998) de 1,80 e 2,70 t.h ${ }^{-1}$, Howe \& Sreesankon (1990) de 2,21 e 2,49 t.h ${ }^{-1}$ e Molina Jr. et al (1995) de 0,96 e 1,26 t.h foram inferiores aos apresentados na Tabela 21 .

A eficiência energética positiva mais alta neste trabalho, considerando-se somente o enfardamento e o enleiramento mais enfardamento foi o tratamento simples, o 
que representa a melhor relação entre a energia disponível no palhiço e a energia equivalente do combustível utilizado. É desejável que a eficiência energética seja positivo e o mais alto possível, para que o recolhimento do palhiço seja tecnicamente viável. As eficiências energéticas não foram determinadas por Molina Jr et al. (1995), porém podem ser estimadas a partir dos dados, por estes determinados, em 99,01 e $98,65 \%$, utilizando-se da equação proposta por Ripoli (1991). Estes valores são menores que os encontrados neste estudo, pois segundo os autores, em suas conclusões, a fonte de potência utilizada não era adequada à enfardadora.

As comparações entre as médias dos dois tratamentos para as variáveis CCt (L.t ${ }^{-}$ $\left.{ }^{1}\right), \mathrm{BE}(\%)$ e BT (\%) diferiram entre si ao nível de significância de $1 \%$ através do teste de Tukey.

O consumo de combustível por tonelada de resíduo enfardado - (CCt), encontrado por Molina Jr. (1991a) de 4,17 L.t ${ }^{-1}$, foi praticamente o dobro do valor encontrado por Molina Jr. et al. (1991b), que foi de 2,30 L.t ${ }^{-1}$ operando com o mesmo modelo de enfardadora nos dois estudos. O valores médios deste estudo foram de 0,64 L.t ${ }^{-1}$ para o enleiramento simples e de 0,43 L.t $^{-1}$ no enleiramento duplo, menores do que os valores citados na bibliografia. Observa-se que o valor desta variável, pode sofrer alterações, devido ao acomodamento do resíduo a ser enfardado (enleirado ou não), pelo modelo de trator utilizado na operação e também do modelo da enfardadora a ser utilizada na operação de enfardamento. Estes fatores podem influenciar o valor desta variável estudada.

Para os valores encontrados nas variáveis $\operatorname{MPenf}\left(\mathrm{t}_{\mathrm{h}} \mathrm{h}^{-1}\right)$ e $\operatorname{MPr}\left(\mathrm{t} . \mathrm{ha}^{-1}\right)$, suas médias não tiveram diferença significativa alguma através do teste de Tukey ao nível de 1 e 5\%. A quantidade de resíduo de colheita de cana-de-açúcar recolhido do campo em relação à massa existente é citada nas bibliografias por seus autores e, são:

Lopez (1987) $83 \%$

Howe \& Sreesangkon (1990) $\quad 71 \%$

Molina Jr. (1991a) e Molina Jr. et al. (1995) 34,34\%

Molina Jr. et al. (1991b) 27,72\% 
Os valores encontrados por Lopez (1987) e Howe \& Sreesangkon (1990) são muito superiores aos encontrados por Molina Jr. (1991a), Molina Jr. et al. (1991b) e os valores encontrados neste estudo que foi de $31 \%$ para o tratamento simples e $41 \%$ para o tratamento duplo. O valor encontrado neste estudo para o tratamento duplo aproximouse do valor encontrado por Molina Jr. (1991), apesar de não ter havido enleiramento. Nos dois trabalhos realizados por Molina Jr. (1991a) e Molina Jr. et al. (1991b), foram feitos com o mesmo tipo de enfardadora, destacando-se o trabalho que encontrou o valor de $34,34 \%$, no entanto esse fato pode ser visto pela situação em que se deu o enfardamento, pois na tentativa de não contaminar o fardo, com matéria estranha mineral, não foi executada a operação de enleiramento do resíduo.

\subsection{Análise de terra contida no palhiço}

$\mathrm{Na}$ Tabela 22 , são apresentados os valores da quantidade de matéria estranha mineral (terra), existente nos fardos, nos dois tratamentos do presente estudo.

Tabela 22. Resultados de terra nos fardos (\%); TSf = terra solta no fardo; Tfolha = terra aderida às folhas e palhas; $\mathrm{IM}=$ percentagem de terra no fardo; $\mathrm{CV}=$ coeficiente de variação; $\mathrm{IC}=$ intervalo de confiança

\begin{tabular}{ccc}
\hline & \multicolumn{3}{c}{ Enfardamentos } & Duplo \\
\hline Variáveis & Simples & 5,51 \\
TSf (\%) & 7,47 & 35,17 \\
Média & 62,73 & {$[4,16 ; 6,85]$} \\
CV & {$[4,22 ; 10,71]$} & \\
IC & & 2,57 \\
Tfolha (\%) & 3,10 & 47,58 \\
Média & 37,64 & {$[1,72 ; 3,41]$} \\
CV & {$[2,29 ; 3,91]$} & \\
IC & & 8,07 \\
IM (\%) & 10,57 & 31,84 \\
Média & 41,45 & {$[6,29 ; 9,85]$} \\
CV & {$[7,53 ; 13,60]$} & \\
IC &
\end{tabular}

$*=1 \%$ de significância; $* *=5 \%$ de significância. 
Os resultados desse estudo obtidos pelas amostras, para identificar a porcentagem de matéria estranha mineral no resíduo enfardado - (IM), demonstrou que o método para detectar a contaminação do fardo pela terra, foi eficiente. A análise das médias das variáveis estudadas, comparadas através do teste de Tukey ao nível de 1 e de $5 \%$ de significância, não deferiram entre si, nas três variáveis analisadas, conforme pode ser visto na Tabela 22 . No entanto, os valores analisados do estudo foram superiores aos encontrados nas citações de outros autores. Pode-se salientar que para os ensaios realizados pelas outras enfardadoras estudadas, existiram fatores que possam esclarecer os valores superiores desse estudo. Por exemplo, as condições climáticas, a qualidade da superficie do solo, o grau de umidade do resíduo enfardado, a velocidade de trabalho, se a área experimental foi enleirada ou não, as diferentes variedades de cana-de-açúcar plantadas nas áreas dos ensaios, o modelo de trator utilizado e o tipo de enleiramento efetuado. Fatores que podem modificar os valores comparados entre as variáveis comparadas do estudo com a de outros autores. Para esse estudo, o enleiramento simples teve maior percentagem de terra, do que o enleiramento duplo, constatou-se que o cilindro recolhedor da enfardadora trabalhava mais próximo do solo, quando estava enfardando o resíduo. Esta observação foi nítida, já que quando a enfardadora estava trabalhando no enleiramento duplo, alem de recolher maior quantidade de resíduo, mantinha uma maior distância do solo, comparado ao enleiramento simples. 


\section{CONCLUSAO}

Face aos resultados obtidos, pode-se concluir que:

$>\mathrm{O}$ recolhimento do palhiço de cana-de-açúcar do ponto de vista operacional, bem como determinar seu potencial energético é viável, após a colheita mecanizada sem queima previa, utilizando-se de um ancinho enleirador de roda de terra e de uma enfardadora cilíndrica de forragem;

$>$ A produtividade média estimada de palhiço, antes das operações de enleiramento e enfardamento, apresentou uma grande variabilidade;

$>\mathrm{O}$ palhiço pelo seu poder calorífico, poderá substituir o uso de combustíveis não renováveis nas usinas e destilarias;

Os dados das capacidades efetivas e operacionais do ancinho enleirador mostraram vantagens na operação de enleiramento simples;

$>$ Os dados das capacidades efetivas e operacionais da enfardadora mostraram vantagens para o enleiramento duplo;

$>$ A massa específica média dos fardos no enleiramento duplo foi superior em confronto com o enleiramento simples;

$>$ A média do índice de terra total nos fardos para o enleiramento simples foi superior a média obtida no enleiramento duplo 


\section{REFERÊNCIAS BIBLIOGRÁFICAS}

ASSOCIAÇÃO BRASILEIRA DE NORMAS TÉCNICAS. Carvão vegetal: método de determinação de poder calorífico; NBR 8633. Rio de Janeiro, 1984. 13p.

AlvareZ, I. A.; CASTRO, P. R. C. Crescimento da parte aérea de cana crua e queimada. Scientia Agricola, v. 56, n. 4, p. 1069 - 1079, 1999.

BALASTREIRE, L. A. Colheita: colheita de feno e forragem. In: BALASTREIRE, L. A. Máquinas agrícolas. São Paulo: Editora Manole, 1987a. cap 8, p. 297-299.

BALASTREIRE, L. A. Gerenciamento de operações agrícolas. In: BALASTREIRE, L. A. Máquinas agrícolas. São Paulo: Editora Manole, 1987b. cap 2, p. 30-61.

BASSINELLO, A. I.; FURLANI NETO, V. L.; MACEDO, N.; PARRAZI, C.; CASAGRANDE, J. C. Implicações agrícolas e industriais da colheita de cana crua. Araras: IAA-PLANALSUCAR, s.d. 55p.

BRITO, J. O.; BARRICHELLO, L.E.G. Aspectos técnicos na utilização da madeira e carvão vegetal como combustíveis. In: SEMINÁRIO DE ABASTECIMENTO ENERGÉTICO INDUSTRIAL COM RECURSOS FLORESTAIS., São Paulo, 1982. Anais. São Paulo: Secretaria de Ciência e Tecnologia, 1982. p.101-108. 
BRITO, S. S. Energia de biomassa: uma alternativa para os trópicos. In: CONGRESSO PANAMERICANO DE ENERGIA, 3., CONVENCION DE LA UNION PANAMERICANA DE ASSOCIACIONES DE INGINIEROS. 19., Guatemala, 1986. Anais. São Paulo: CONFEA-CREA, 1986. p. 1-20.

CENTRO NACIONAL DE REFERÊNCIA EM BIOMASSA BRASIL. Cana-deAçúcar no Brasil. http: infoener.iee.usp/scripts/biomassa/br_ cana.asp. (10 maio 2002a).

CENTRO NACIONAL DE REFERÊNCIA EM BIOMASSA BRASIL. Carvão vegetal no Brasil. http: infoener.iee.usp/scripts/biomassa/br_carvão.asp. (10 maio 2002b).

CENTRO NACIONAL DE REFERÊNCIA EM BIOMASSA BRASIL. A IMPORTANCIA E O POTENCIAL DA COGERACAO DE ENERGIA A PARTIR DA BIOMASSA. http: www.cenbio.org.br. (10 maio 2002c).

CERRI, C.C.; POLO, A.; ANDREUX, F.; LOBO, M.C.; EDUARDO, P.E. Resíduos orgânicos da agroindústria canavieira: 1. Características físicas e químicas. STAB. Açúcar, Álcool e Subprodutos, v.6, n. 3, p. 34-37, jan /fev, 1988.

COOPERATIVA DE PRODUTORES DE CANA, ACÚCAR E ÁlCOOL DO ESTADO DE SÃO PAULO - PROJETO BRA/96/G31. Impactos ambientais do uso em larga escala de sistemas BIG-GT na indústria da cana-de-açúcar. Projeto BRA/96/G31: Geração de energia por biomassa, bagaço da cana-de-açúcar e resíduos. STAB. Açúcar, Álcool e Subprodutos, v.16, n. 5, p. 36-39, mai/jun. 1998. 
COOPERATIVA DE PRODUTORES DE CANA, ACÚCAR E ÁlCOOL DO ESTADO DE SÃO PAULO - PROJETO BRA/96/31. Efeito agronômico da palha remanescente de canaviais colhidos mecanicamente sem a utilização da queimada. Cenbio Notícias, v.4, n.12, 2001. http://www.cenbio.org.br/index 1.htm. (05 nov. 2001)

DELGADO, A. A. Os efeitos da queima dos canaviais. STAB. Açúcar, Álcool e Subprodutos, v.3, n.6, p.42-45, jul./ago, 1985.

DOAT, A. Le pouvoir calorifique des bois tropical. Bois et Forest des Tropiques, v.172, p.33-48, 1977.

FERREIRA, L.J.; DONADONI JUNIOR, R.; FERRARI, S.E.; SIMIONI, C.J.; GERALDI FILHO, L.; ALONSO, O; NAGUMO, M.; JUSTO, P.R.; PAGGIARO, C.M. Sistema de determinação e controle da quantidade de terra na cana-de-açúcar utilizado pela usina da barra. STAB. Açúcar, Álcool e Subprodutos, v.12, n.6, p.35-38, jul./ago., 1994.

FNP CONSULTORIA \& Comércio. AGRIANUAL 2003: anuário de agricultura brasileira. São Paulo, 2003.p.272-273: Cana-de-açúcar.

EMPRESA BRASILEIRA DE PESQUISA AGROPECUÁRIA. Agroecologia da Cana-de-Açúcar._http: www.cnpm.embrapa.br projetos cana index.html. (28 set. 2002).

FURLANI NETO, V.L. Colheita mecanizada da cana-de-açúcar. STAB. Açúcar, Álcool e Subprodutos, v.12, n.13, p 8-9,1994.

GOMES, F.P. Curso de Estatística Experimental. 14. ed. Piracicaba: Editora Nobel, 2000. $447 \mathrm{p}$ 
HOWE; SREESANGKON, P. Costs and performance of equipament for baling sugar cane tops and leaves. S. I. United States Agency of Internacional Development, 1990. 56. p.

INSTITUTO NACIONAL de EFICIÊNCIA ENERGÉTICA. O que e cogeração?. www.inee.org.br/forum_co_cogeração.asp?Cat=forum. (12 dez. 2002).

JORNAL de Piracicaba. Energia co-gerada depende de preços. Jornal de Piracicaba, Piracicaba, 29 mar. 2001. p. B-4.

LANÇAS, K. P. A evolução das alternativas energéticas com a crise do petróleo e a produção da biomassa. Botucatu: Unesp, 1984. 34p.

LOPEZ, P. A. Recolecion de barbojo como fuente energética en el Central Romana. In: LOPEZ, P. A. Uso alternativo de la caña de azúcar para energía y alimento. México: GRUPO DE PAÍSES LATINOAMERICANOS Y DEL CARIBE EXPORTADORES DE AZÚCAR, 1987. p. 57-62 (Coleción GEPLACEA).

MASCHIO, A. Energia co-gerada depende de preços. Jornal de Piraciçaba, Piracicaba, 29 mar., 2001. p. B-4.

MIALHE, L. G. Desempenho operacional da maquinaria agrícola. In: MIALHE, L. G. Manual de mecanização agrícola. São Paulo: Ceres, 1974. cap 5, p. 117-126.

MIALHE, L. G. Combustão e combustíveis. In: MIALHE, L. G. Máquinas motoras na agricultura. SãoPaulo: Ceres, 1980. cap.9, p. 187-212.

MIALHE, L. G. Máquinas agrícolas: ensaios \& certificação. Piracicaba: FEALQ, 1996. $722 p$. 
MIRANDA, E. E. Produtos. www.única.com.br.pages cana produtos.asp. (12 dez. 2002).

MOLINA JUNIOR, W. F. Enfardamento de resíduo de colheita de cana-de-açúcar (Saccharum spp): avaliação dos desempenhos operacional e econômico. Piracicaba, 1991a. 101p. Dissertação (Mestrado) - Escola Superior de Agricultura " Luiz de Queiroz", Universidade de São Paulo.

MOLINA JUNIOR, W. F.; RIPOLI, T. C.; GERALDI, R. N.; AMARAL, J.R.; Aspectos econômicos e operacionais do enfardamento de resíduo de colheita de cana-de-açúcar para aproveitamento energético. STAB. Açúcar, Álcool e Subprodutos, v.13, n.5, p. 28-31, mai/jun. 1995.

MOLINA JUNIOR, W. F.; RIPOLI, T. C.; COELHO, J.C.D.; AMARAL, J.R.; SACCOMANO, J. B. Estudo preliminar sobre enfardamento de resíduos de colheita de cana-de-açúcar (saccharum spp). IN: CONGRESSO BRASILEIRO DE ENGENHARIA AGRÍCOLA 20., Londrina, 1991a. Resumos. Londrina: SBEA, 1991b. p. 26.

NASCIMNETO, M. J.M.; QUEIROZ, L. C.. Autoprodução de energia elétrica através de gaseificação de bagaço de cana. situação atual e perspectivas. STAB. Açúcar, Álcool e Subprodutos, v.11, n. 5, p. 3 - 7, 1993.

OLIVEIRA, E. R. Bagaço de cana: um combustível que ainda não recebeu a devida atenção. Álcool e Açúcar, v.2, n.4, p. 10-19, maio/jun. 1982.

RIPOLI, T. C. Fogo na palha? Notícias da ESALQ, v.1, n.5, p. 2-3, nov., 1988. 
RIPOLI, T. C. Utilização do material remanescente da colheita da cana-de-açúcar (saccharum spp) - Equacionamento dos balanços energéticos e econômicos. Piracicaba , 1991. 150p. Tese (Livre-Docência) - Escola Superior de Agricultura "Luiz de Queiroz", Universidade de São Paulo.

RIPOLI, T. C. O uso energético da biomassa da cana: implicações técnico-econômicas e sócio-ambientais. In: SEMINÁRIO INTERNACIONAL SOBRE DESENVOLVIMENTO SUSTENTADO AGRÍCOLA E URBANO, 1., Piracicaba, 1995. Anais. Piracicaba: ESALQ, 1995. p.131-142.

RIPOLI, T.C.C. ; MOLINA JR, W. F. Cultura canavieira: um desperdício energético. Maquinaria Agrícola, v.6, n.1, p.2-3, 1991.

RIPOLI, T. C.; MIALHE, L. G.; BRITO, J. O. Queima de canavial: o desperdício não mais admissível! Álcool \& Açúcar, v.10, n.54, p. 18-23, 1990.

RIPOLI, T. C.; FURLANI NETO, V. L.; VILLA NOVA, N. A. Biomassa de cana-deaçúcar: energia contida no palhiço remanescente de colheita mecânica. STAB. Açúcar, Álcool e Subprodutos, v.15, n. 4, p 24-27, 1997.

RIPOLI, T. C. C., MOLINA JUNIOR., W. F.; RIPOLI, M. L. C. Potencial da energia de biomassa da cana-de-açúcar no Brasil. Scientia Agricola., v. 57, n.4, p.677-681, $2000 a$.

RIPOLI, T.C.; MOLINA JNIOR.,W. F.; RIPOLI, M.L.C. Energetic potencial of the sugar cane biomass in Brazil. Rivista de Ingegneria Agrária, n.1, p.2-7, Feb. 2000b. 
RIPOLI, T. C.; MOLINA JUNIOR, W. F.; NOGUEIRA, M. C. S.; MATOS, J. R. Equivalente energético do palhiço da cana-de-açúcar. In: CONGRESSO BRASILEIRO DE ENGENHARIA AGRÍCOLA, 19., Piracicaba, 1990. Anais. Piracicaba: FEALQ, SBEA, 1990, p.249-262.

RIPOLI, T.C.; MOLINA JUNIOR, W. F.; STUPIELO, J. P.; NOGUEIRA, M. C. SACCOMANO, J. B. Potencial energetico de residuos de cosecha de la cana verde. STAB. Açúcar, Álcool e Subprodutos, v.10, n. 1, p.23 - 26, set/ out., 1991.

SECRETARIA do MEIO AMBIENTE. Secretaria do Meio Ambiente exige que queima de palha de cana seja comunicada com antecedência de 48 horas. www:ambiente.sp.gov.Br/index.htm. (16 abril 2002).

STANIFORTH, A.R. Straw for fuel and fertiliser?. Suffolk, Farming Press, 1982. $153 \mathrm{p}$.

STUPIELLO, J. P. A cana-de-açúcar como matéria-prima. In: PARANHOS, S. B., coord. Cana-de-açúcar: cultivo e utilização. Campinas: Fundação Cargill, 1987. v. 1. cap. 7, p. 761-804.

STUPIELLO, J. P. Alguns aspectos da qualidade da matéria-prima. STAB. Açúcar, Álcool e Subproduto, v.7, n. 3/5, p. 52-54, jun./jul., 1989.

TOMICIOLI, A. R. Deputados aprovam o fim da queima da palha da cana no Estado de São Paulo. wwww.florestasite.com.br.noticiascana.htm. (01 out. 2002).

UNIÃO DA AGROINDUSTRIA CANAVIEIRA DE SÃO PAULO. Co-geração de energia elétrica. www.única.com.br. (12 dez. 2002). 
USINA DA BARRA. Aproveitamento energético: experiências da. STAB. Açúcar, Álcool e Subprodutos, v. 20, p. 38-39, nov. / dez., 2001.

ZARPELON, F. Panorama da cogeração em alguns países produtores de cana-de-açúcar. STAB. Açúcar, Álcool e Subprodutos, v. 11, p.10-13, jan./fev., 1993. 
APÊNDICES 


\begin{tabular}{|c|c|c|c|c|c|c|}
\hline Repetições & $\begin{array}{l}\text { MA } \\
(\mathrm{kg})\end{array}$ & $\begin{array}{l}\text { MPont } \\
\text { (kg) }\end{array}$ & $\begin{array}{l}\mathrm{MFc} \\
(\mathrm{kg})\end{array}$ & $\begin{array}{l}\text { MT } \\
(\mathrm{kg})\end{array}$ & $\begin{array}{c}\mathrm{U} \\
(\%)\end{array}$ & 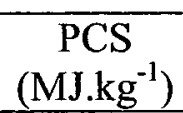 \\
\hline 1 & 2,69 & 0,03 & 0,67 & 0,20 & 26,09 & 17,08 \\
\hline 2 & 2,09 & 0,02 & 0,39 & 0,30 & 23,02 & 18,19 \\
\hline 3 & 2,29 & 0,05 & 0,45 & 0,07 & 23,92 & 18,86 \\
\hline 4 & 4,19 & 0,08 & 1,05 & 0,22 & 30,90 & 17,60 \\
\hline 5 & 4,09 & 0,03 & 0,93 & 0,14 & 27,48 & 18,53 \\
\hline 6 & 3,79 & 0,18 & 0,94 & 0,12 & 34,43 & 19,47 \\
\hline 7 & 1,29 & 0,03 & 0,32 & 0,07 & 15,01 & 20,01 \\
\hline 8 & 1,89 & 0,04 & 0,43 & 0,08 & 16,03 & 18,98 \\
\hline 9 & 2,19 & 0,12 & 0,33 & 0,09 & 22,09 & 17,51 \\
\hline 10 & 1,89 & 0,03 & 0,54 & 0,07 & 19,47 & 18,34 \\
\hline 11 & 3,39 & 0,07 & 0,88 & 0,20 & 13,88 & 17,51 \\
\hline 12 & 2,29 & 0,05 & 0,42 & 0,27 & 12,87 & 17,29 \\
\hline 13 & 3,49 & 0,02 & 0,42 & 0,55 & 19,87 & 17,21 \\
\hline 14 & 2,49 & 0,08 & 0,56 & 0,04 & 21,94 & 18,88 \\
\hline 15 & 2,39 & 0,09 & 0,38 & 0,13 & 34,99 & 20,90 \\
\hline
\end{tabular}

\begin{tabular}{lcc}
\hline Variáveis & Unidades & \\
\hline Velocidade & $\left(\mathrm{km} . \mathrm{h}^{-1}\right)$ & 8,6 \\
Rotação do motor & $(\mathrm{rpm})$ & 2100 \\
Marcha & & $3-$ média \\
Tempo total & $(\mathrm{s})$ & 633,45 \\
Tempo de abastecimento & $(\mathrm{s})$ & 74,11 \\
Consumo de combustível & $(\mathrm{mL})$ & 2560 \\
\hline
\end{tabular}

Quadro 2 - Determinações volumétricas e temporais no enleiramento simples 


\begin{tabular}{cccc}
\hline Repetições & $\begin{array}{c}\text { LTA } \\
(\mathrm{m})\end{array}$ & $\begin{array}{c}\text { LUA } \\
(\mathrm{m})\end{array}$ & $\begin{array}{c}\text { LME } \\
(\mathrm{m})\end{array}$ \\
\hline 1 & 26,80 & 21,80 & 3,63 \\
2 & 27,82 & 23,16 & 3,86 \\
3 & 26,40 & 21,77 & 3,63 \\
4 & 26,20 & 21,68 & 3,61 \\
5 & 26,25 & 20,52 & 3,42 \\
6 & 27,30 & 21,99 & 3,67 \\
7 & 27,10 & 22,96 & 3,83 \\
8 & 26,90 & 22,33 & 3,72 \\
9 & 26,60 & 21,89 & 3,65 \\
10 & 26,00 & 20,90 & 3,48 \\
\hline
\end{tabular}

Quadro 3 - Largura das áreas no enleiramento simples de 6 leiras. LTA = largura total da área; LUA = largura útil da área; LME = largura média da faixa enleirada

\begin{tabular}{cc}
\hline Repetições & CA \\
& $(\mathrm{m})$ \\
\hline 1 & 249,85 \\
2 & 249,20 \\
3 & 251,66 \\
4 & 241,66 \\
\hline
\end{tabular}

Quadro 4 - Comprimento das áreas (CA) no enleiramento simples

\begin{tabular}{lcc}
\hline Variáveis & Unidades & \\
\hline Velocidade & $\left(\mathrm{km} \cdot \mathrm{h}^{-1}\right)$ & 8,6 \\
Rotação do motor & $(\mathrm{rpm})$ & 2100 \\
Marcha & & $3-$ média \\
Tempo total & $(\mathrm{s})$ & 1687 \\
Tempo de abastecimento & $(\mathrm{s})$ & 39,4 \\
Consumo de combustível & $(\mathrm{mL})$ & 5830 \\
\hline
\end{tabular}

Quadro 5 - Determinações volumétricas e temporais no enleiramento duplo 


\begin{tabular}{ccc}
\hline Repetições & $\begin{array}{c}\text { TEenl. } \\
(\mathrm{s})\end{array}$ & $\begin{array}{c}\text { TMenl. } \\
(\mathrm{s})\end{array}$ \\
\hline 1 & 244 & 25 \\
2 & 210 & 20 \\
3 & 209 & 14 \\
4 & 199 & 17 \\
5 & 190 & 17 \\
6 & 185 & 25 \\
7 & 175 & 7 \\
8 & 25 & 0 \\
\hline
\end{tabular}

Quadro 6 - Tempos dos ciclos operacionais no enleiramento duplo. TEenl. = tempo efetivo ; TMenl. $=$ tempo de manobra

\begin{tabular}{ccccccccc}
\hline Repetições & $\begin{array}{c}\text { LTA } \\
(\mathrm{m})\end{array}$ & $\begin{array}{c}\text { LFE1 } \\
(\mathrm{m})\end{array}$ & $\begin{array}{c}\text { LFE2 } \\
(\mathrm{m})\end{array}$ & $\begin{array}{c}\text { LFE3 } \\
(\mathrm{m})\end{array}$ & $\begin{array}{c}\text { LFE4 } \\
(\mathrm{m})\end{array}$ & $\begin{array}{c}\text { LFE5 } \\
(\mathrm{m})\end{array}$ & $\begin{array}{c}\text { LFE6 } \\
(\mathrm{m})\end{array}$ & $\begin{array}{c}\text { LFE7 } \\
(\mathrm{m})\end{array}$ \\
\hline 1 & 37,26 & 5,78 & 5,67 & 5,29 & 4,84 & 5,03 & 5,66 & 4,99 \\
2 & 37,73 & 6,11 & 5,80 & 5,48 & 4,65 & 5,10 & 5,28 & 5,31 \\
3 & 39,24 & 6,18 & 6,10 & 5,58 & 4,90 & 5,43 & 5,37 & 5,68 \\
4 & 39,90 & 6,41 & 6,38 & 5,52 & 4,89 & 5,45 & 5,36 & 5,89 \\
5 & 41,37 & 6,45 & 6,48 & 6,30 & 5,01 & 5,70 & 5,55 & 5,88 \\
6 & 42,09 & 6,63 & 6,42 & 6,50 & 4,85 & 5,46 & 5,92 & 6,31 \\
7 & 43,69 & 6,41 & 7,09 & 6,79 & 5,28 & 6,19 & 5,92 & 6,01 \\
8 & 43,47 & 6,33 & 6,98 & 6,52 & 5,77 & 5,90 & 5,77 & 6,20 \\
9 & 44,57 & 6,73 & 7,13 & 6,36 & 6,01 & 5,81 & 5,97 & 6,56 \\
10 & 45,48 & 6,81 & 7,04 & 6,52 & 6,21 & 5,86 & 6,11 & 6,93 \\
11 & 47,50 & 6,50 & 7,22 & 7,22 & 6,27 & 6,67 & 6,8 & 6,82 \\
12 & 47,77 & 6,41 & 7,27 & 7,18 & 6,31 & 6,44 & 6,85 & 7,31 \\
13 & 48,88 & 7,08 & 7,31 & 7,31 & 6,68 & 6,68 & 6,68 & 7,14 \\
14 & 48,82 & 6,89 & 7,22 & 7,50 & 6,60 & 6,51 & 6,70 & 7,40 \\
15 & 50,49 & 7,59 & 7,79 & 7,41 & 6,89 & 6,54 & 7,04 & 7,23 \\
\hline
\end{tabular}

Quadro 7 - Larguras das áreas no enleiramento duplo. LTA = largura total da área; $\mathrm{LFE}=$ largura da faixa de enleiramento

\begin{tabular}{cc}
\hline Repetições & $\begin{array}{l}\text { CA } \\
(\mathrm{m})\end{array}$ \\
\hline 1 & 242,25 \\
2 & 244,00 \\
3 & 251,44 \\
4 & 234,15 \\
5 & 241,66 \\
\hline
\end{tabular}

Quadro 8 - Comprimentos das áreas (CA) no enleiramento duplo 


\begin{tabular}{cccccc}
\hline Tratamentos & $\begin{array}{c}\text { Alturas } \\
(\mathrm{m})\end{array}$ & $\begin{array}{c}\text { Diâmetros } \\
(\mathrm{m})\end{array}$ & $\begin{array}{c}\text { Massas } \\
(\mathrm{kg})\end{array}$ & $\begin{array}{c}\text { Distâncias } \\
(\mathrm{m})\end{array}$ & $\begin{array}{c}\text { Tempos } \\
(\mathrm{s})\end{array}$ \\
\hline CR1S1 & 1,20 & 1,65 & 425,00 & 105,60 & 133,60 \\
CR2S1 & 1,23 & 1,70 & 447,00 & 119,05 & 160,66 \\
CR3S1 & 1,20 & 1,70 & 454,80 & 180,30 & 210,41 \\
CR4S1 & 1,21 & 1,66 & 472,20 & 285,40 & 359,36 \\
\hline Quadro 9 - Dimensões e massas das fardos cilíndricos, distâncias e tempos de \\
enfardamento no enleiramento simples
\end{tabular}

\begin{tabular}{lccc}
\hline Tratamentos & $\begin{array}{c}\text { MAS } \\
(\mathrm{kg})\end{array}$ & $\begin{array}{c}\text { MPS } \\
(\mathrm{kg})\end{array}$ & $\begin{array}{c}\text { MBS } \\
(\mathrm{kg})\end{array}$ \\
\hline CR1S1 & 2,94 & 0,39 & 0,23 \\
CR1S2 & 1,28 & 0,15 & 0,09 \\
CR2S1 & 1,98 & 0,46 & 0,32 \\
CR2S2 & 1,98 & 0,46 & 0,33 \\
CR3S1 & 1,52 & 0,16 & 0,10 \\
CR3S2 & 1,61 & 0,20 & 0,09 \\
CR4S1 & 1,87 & 0,18 & 0,11 \\
CR4S2 & 1,86 & 0,15 & 0,08 \\
\hline
\end{tabular}

Quadro 10 - Massa das amostras obtidas pela sonda da usina e das quantidades de terra obtidas por peneiramento no tratamento cilíndrico simples. MAS = massa das amostras da sonda; MPS = massa de terra obtida da peneira de malha larga; MBS = massa de terra através da bateria de peneiras

\begin{tabular}{lll}
\hline Tratamentos & $\begin{array}{l}\text { MU } \\
(\mathrm{kg})\end{array}$ & $\begin{array}{l}\mathrm{MS} \\
(\mathrm{kg})\end{array}$ \\
\hline CR1S1 & 0,01 & 0,01 \\
CR1S2 & 0,03 & 0,03 \\
CR2S1 & 0,02 & 0,01 \\
CR2S2 & 0,01 & 0,01 \\
CR3S1 & 0,03 & 0,03 \\
CR3S2 & 0,02 & 0,02 \\
CR4S1 & 0,03 & 0,02 \\
CR4S2 & 0,03 & 0,02 \\
\hline
\end{tabular}

Quadro 11 - Massas das sub-amostras para determinação da umidade do palhiço enfardado obtidas pela sonda da usina no tratamento cilíndrico simples. $\mathrm{MU}=$ massa em base úmida da sub-amostra da sonda; $\mathrm{MS}=$ massa em base seca da sub-amostra da sonda 


\begin{tabular}{cccccc}
\hline Tratamentos & $\begin{array}{c}\text { Alturas } \\
(\mathrm{m})\end{array}$ & $\begin{array}{c}\text { Diâmetros } \\
(\mathrm{m})\end{array}$ & $\begin{array}{c}\text { Massas } \\
(\mathrm{kg})\end{array}$ & $\begin{array}{c}\text { Distâncias } \\
(\mathrm{m})\end{array}$ & $\begin{array}{c}\text { Tempos } \\
(\mathrm{s})\end{array}$ \\
\hline CR1D1 & 1,20 & 1,58 & 472,30 & 71,00 & 119,41 \\
CR2D1 & 1,19 & 1,60 & 456,10 & 57,90 & 114,66 \\
CR3D1 & 1,19 & 1,66 & 440,60 & 73,30 & 126,95 \\
CR5D1 & 1,10 & 1,55 & 423,40 & 93,40 & 142,07 \\
\hline
\end{tabular}

Quadro 12 - Dimensões e massas das fardos cilíndricos, distâncias e tempos de enfardamento no enleiramento duplo

\begin{tabular}{lccc}
\hline Tratamentos & $\begin{array}{c}\text { MAS } \\
(\mathrm{kg})\end{array}$ & $\begin{array}{c}\text { MPS } \\
(\mathrm{kg})\end{array}$ & $\begin{array}{c}\text { MBS } \\
(\mathrm{kg})\end{array}$ \\
\hline CR1D1 & 1,33 & 0,14 & 0,06 \\
CR1D2 & 0,76 & 0,07 & 0,04 \\
CR2D1 & 2,53 & 0,27 & 0,16 \\
CR2D2 & 2,47 & 0,35 & 0,18 \\
CR3D1 & 1,04 & 0,10 & 0,05 \\
CR3D2 & 2,67 & 0,38 & 0,21 \\
CR5D1 & 0,83 & 0,07 & 0,05 \\
CR5D2 & 2,89 & 0,48 & 0,32 \\
\hline
\end{tabular}

Quadro 13 - Massas das amostras obtidas pela sonda da usina e das quantidades de terra obtidas por peneiramento no tratamento cilíndrico simples. MAS = massa das amostras da sonda; MPS = massa de terra obtida da peneira de malha larga; $\mathrm{MBS}=$ massa de terra através da bateria de peneiras

\begin{tabular}{ccc}
\hline Tratamentos & $\begin{array}{c}\text { MU } \\
(\mathrm{kg})\end{array}$ & $\begin{array}{l}\mathrm{MS} \\
(\mathrm{kg})\end{array}$ \\
\hline CR1D1 & 0,03 & 0,02 \\
CR1D2 & 0,03 & 0,02 \\
CR2D1 & 0,02 & 0,01 \\
CR2D2 & 0,02 & 0,01 \\
CR3D1 & 0,04 & 0,03 \\
CR3D2 & 0,03 & 0,02 \\
CR5D1 & 0,02 & 0,02 \\
CR5D2 & 0,02 & 0,02 \\
\hline
\end{tabular}

Quadro 14 - Massas das amostras obtidas pela sonda da usina e das quantidades de terra obtidas por peneiramento no tratamento cilíndrico duplo. MAS = massa das amostras da sonda; MPS = massa de terra obtida da peneira de malha larga; MBS $=$ massa de terra através da bateria de peneiras 


\begin{tabular}{ccccc}
\hline Amostras & $\begin{array}{c}\text { Argila } \\
(\%)\end{array}$ & $\begin{array}{c}\text { Silte } \\
(\%)\end{array}$ & $\begin{array}{c}\text { Areia } \\
(\%)\end{array}$ & $\begin{array}{c}\text { Umidade } \\
(\%)\end{array}$ \\
\hline $28 \mathrm{P} 15$ & 10,78 & 18,61 & 70,61 & 10,44 \\
$01 \mathrm{P} 14$ & 12,41 & 17,74 & 69,95 & 11,78 \\
$25 \mathrm{P} 15$ & 8,66 & 21,74 & 69,6 & 10,78 \\
$18 \mathrm{P} 13$ & 14,69 & 18,22 & 67,09 & 10,52 \\
$05 \mathrm{P} 15$ & 16,14 & 17,72 & 66,14 & 14,33 \\
\hline
\end{tabular}

Amostras classificadas como Franco Arenoso

Quadro 15 - Análise granulométrica e umidade do solo

\begin{tabular}{ccc}
\hline Tratamentos & $\begin{array}{c}\text { MTP } \\
(\mathrm{kg})\end{array}$ & $\begin{array}{c}\text { MTC } \\
(\mathrm{kg})\end{array}$ \\
\hline CR1S $1 / 2$ & 0,005 & 0,004 \\
CR2S $1 / 2$ & 0,006 & 0,005 \\
CR3S 1/2 & 0,003 & 0,002 \\
CR4S 1/2 & 0,003 & 0,002 \\
\hline
\end{tabular}

Quadro 16 - Resultados das sub-amostras de terra obtidas através da bateria de peneiras no tratamento cilíndrico simples e queimadas na mufla. MTP $=$ massa de terra mais particulado vegetal em base seca; $\mathrm{MTC}=$ massa de terra mais cinzas

\begin{tabular}{ccc}
\hline Tratamentos & $\begin{array}{c}\text { MTP } \\
(\mathrm{kg})\end{array}$ & $\begin{array}{c}\text { MTC } \\
(\mathrm{kg})\end{array}$ \\
\hline CR1D 1/2 & 0,005 & 0,004 \\
CR1D 1/2 & 0,003 & 0,002 \\
CR3D 1/2 & 0,004 & 0,003 \\
CR5D 1/2 & 0,005 & 0,004 \\
\hline
\end{tabular}

Quadro 17 - Resultados das sub-amostras de terra obtidas através da bateria de peneiras no tratamento cilíndrico duplo e queimadas na mufla. MTP = massa de terra mais particulado vegetal em base seca; $\mathrm{MTC}=$ massa de terra mais cinzas 


\begin{tabular}{lcc}
\hline Tratamentos & $\begin{array}{c}\text { MAS } \\
\left(10^{-3} \cdot \mathrm{kg}\right)\end{array}$ & $\begin{array}{c}\text { MCS } \\
\left(10^{-3} \cdot \mathrm{kg}\right)\end{array}$ \\
\hline CR1S1(L) & 1,82 & 0,06 \\
CR1S2(L) & 1,72 & 0,06 \\
CR2S1(L) & 1,77 & 0,06 \\
CR2S2(L) & 1,87 & 0,07 \\
CR3S1(L) & 1,47 & 0,06 \\
CR3S2(L) & 1,03 & 0,05 \\
CR4S1(L) & 1,32 & 0,05 \\
CR4S2(L) & 1,01 & 0,04 \\
\hline CR1S1(NL) & 1,61 & 0,09 \\
CR1S2(NL) & 0,43 & 0,11 \\
CR2S1(NL) & 1,75 & 0,11 \\
CR2S2(NL) & 1,52 & 0,10 \\
CR3S1(NL) & 0,49 & 0,09 \\
CR3S2(NL) & 0,79 & 0,12 \\
CR4S1(NL) & 0,72 & 0,11 \\
CR4S2(NL) & 0,63 & 0,11 \\
\hline
\end{tabular}

Quadro 18 - Cinzas de folhas de palhiço lavadas (L) e não lavadas (NL) no tratamento cilíndrico simples para a determinação de terra aderida as folhas. MAS $=$ massa de palhiço triturado em base seca; $\mathrm{MCS}$ = massa de cinzas (cinzas mais terra nas amostras lavadas)

\begin{tabular}{lll}
\hline Tratamentos & $\begin{array}{c}\text { MAS } \\
(\mathrm{kg})\end{array}$ & $\begin{array}{c}\text { MCS } \\
(\mathrm{kg})\end{array}$ \\
\hline CR1D1(L) & 1,15 & 0,06 \\
CR1D2(L) & 1,47 & 0,05 \\
CR2D1(L) & 1,37 & 0,05 \\
CR2D2(L) & 1,88 & 0,08 \\
CR3D1(L) & 1,11 & 0,04 \\
CR3D2(L) & 1,76 & 0,08 \\
CR5D1(L) & 1,75 & 0,07 \\
CR5D2(L) & 2,30 & 0,08 \\
\hline CR1D1(NL) & 0,46 & 0,10 \\
CR1D2(NL) & 1,62 & 0,10 \\
CR2D1(NL) & 0,82 & 0,22 \\
CR2D2(NL) & 1,30 & 0,09 \\
CR3D1(NL) & 0,58 & 0,12 \\
CR3D2(NL) & 1,52 & 0,08 \\
CR5D1(NL) & 1,67 & 0,10 \\
CR5D2(NL) & 1,56 & 0,12 \\
\hline
\end{tabular}

Quadro 19 - Cinzas de folhas de palhiço não lavadas (NL) no tratamento cilíndrico simples para a determinação de terra aderida as folhas. MAS = massa de palhiço triturado em base seca; $\mathrm{MCS}=$ massa de cinzas (cinzas mais terra nas amostras lavadas) 
Tabela 1. Percentagem dos constituintes e sua produtividade estimadas do palhiço, antes da operação de enleiramento. IF = índice de folhas; IC = índice de frações de colmos; IPont = índice de ponteiros; $\mathrm{IM}=$ índice de terra total;

$\mathrm{PE}=$ produtividade estimada

\begin{tabular}{cccccc}
\hline Repetições & $\begin{array}{c}\text { IF } \\
(\%)\end{array}$ & $\begin{array}{c}\text { IC } \\
(\%)\end{array}$ & $\begin{array}{c}\text { IPont } \\
(\%)\end{array}$ & $\begin{array}{c}\text { IM } \\
(\%)\end{array}$ & $\begin{array}{c}\text { PE } \\
\left(\text { t.ha }^{-1}\right)\end{array}$ \\
\hline 1 & 66,23 & 1,22 & 25,04 & 7,51 & 26,94 \\
2 & 65,73 & 1,09 & 18,66 & 14,51 & 20,94 \\
3 & 75,07 & 2,31 & 19,41 & 3,21 & 22,94 \\
4 & 67,92 & 1,80 & 24,97 & 5,31 & 41,94 \\
5 & 73,09 & 0,66 & 22,83 & 3,42 & 40,94 \\
6 & 67,06 & 4,84 & 24,83 & 3,27 & 37,94 \\
7 & 67,52 & 2,04 & 24,96 & 5,48 & 12,94 \\
8 & 71,23 & 1,89 & 22,82 & 4,06 & 18,94 \\
9 & 75,41 & 5,45 & 15,10 & 4,04 & 21,94 \\
10 & 66,43 & 1,35 & 28,38 & 3,84 & 18,94 \\
11 & 66,16 & 1,92 & 25,98 & 5,94 & 33,94 \\
12 & 67,52 & 2,22 & 18,44 & 11,82 & 22,94 \\
13 & 71,64 & 0,48 & 12,04 & 15,85 & 34,94 \\
14 & 72,95 & 3,11 & 22,48 & 1,46 & 24,94 \\
15 & 75,04 & 3,65 & 15,67 & 5,64 & 23,94 \\
\hline
\end{tabular}

Tabela 2. Poderes caloríficos e umidade do palhiço. $U=$ umidade; $P C S=$ poder calorífico superior; $\mathrm{PCI}=$ poder calorífico inferior; $\mathrm{PCU}=$ poder calorífico útil; $\mathrm{PEP}=$ potencial energético do palhiço

\begin{tabular}{|c|c|c|c|c|c|}
\hline Repetições & $\begin{array}{c}U \\
(\%)\end{array}$ & 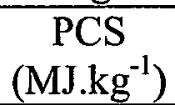 & $\begin{array}{c}\text { PCI } \\
\left(\mathrm{MJ} . \mathrm{kg}^{-1}\right)\end{array}$ & $\begin{array}{c}\text { PCU } \\
\left(\mathrm{MJ} \mathrm{kg}^{-1}\right)\end{array}$ & $\begin{array}{c}\text { PEP } \\
\left({\left.\mathrm{MJ} . h a^{-1}\right)}^{2}\right.\end{array}$ \\
\hline 1 & 26,09 & 17,08 & 15,66 & 11,42 & 460080 \\
\hline 2 & 23,02 & 18,19 & 16,77 & 12,75 & 380845 \\
\hline 3 & 23,92 & 18,86 & 17,44 & 13,11 & 432684 \\
\hline 4 & 24,65 & 17,60 & 16,18 & 12,04 & 738199 \\
\hline 5 & 27,48 & 18,53 & 17,12 & 12,26 & 758821 \\
\hline 6 & 24,43 & 19,47 & 18,06 & 13,49 & 738798 \\
\hline 7 & 15,01 & 20,01 & 18,60 & 15,65 & 258967 \\
\hline 8 & 16,03 & 18,98 & 17,57 & 14,59 & 359537 \\
\hline 9 & 22,09 & 17,51 & 16,10 & 12,38 & 384244 \\
\hline 10 & 19,47 & 18,34 & 16,92 & 13,47 & 347405 \\
\hline 11 & 13,88 & 17,51 & 16,10 & 13,70 & 594404 \\
\hline 12 & 12,87 & 17,29 & 15,87 & 13,67 & 396571 \\
\hline 13 & 19,87 & 17,21 & 15,79 & 12,50 & 601385 \\
\hline 14 & 21,94 & 18,88 & 17,46 & 13,48 & 470929 \\
\hline 15 & 20,69 & 20,90 & 19,48 & 15,29 & 500258 \\
\hline
\end{tabular}


Tabela 3. Área enleirada, massa de palhiço enleirado, capacidade efetiva e operacional e balanço energético no tratamento simples. $\mathrm{AE}=$ área enleirada; $\mathrm{MA}=$ massa estimada de palhiço enleirado; $\mathrm{CE}=$ capacidade efetiva; $\mathrm{CO}=$ capacidade operacional; $\mathrm{CA}=$ consumo de combustível por hectare; $\mathrm{CM}=$ consumo de combustível por tonelada; $\mathrm{BE}=$ balanço energético

\begin{tabular}{cccccccc}
\hline Repetições & $\begin{array}{c}\mathrm{AE} \\
\text { (ha) }\end{array}$ & $\begin{array}{c}\mathrm{MA} \\
\text { (t) }\end{array}$ & $\begin{array}{c}\mathrm{CE} \\
\left(\mathrm{t.h}^{-1}\right)\end{array}$ & $\begin{array}{c}\mathrm{CO} \\
\left(\mathrm{t.h}^{-1}\right)\end{array}$ & $\begin{array}{c}\mathrm{CA} \\
\left(\mathrm{L.ha}^{-1}\right)\end{array}$ & $\begin{array}{c}\mathrm{CM} \\
\left(\mathrm{L.t} \mathrm{t}^{-1}\right)\end{array}$ & $\begin{array}{c}\mathrm{BE} \\
(\%)\end{array}$ \\
\hline 1 & 0,54 & 14,55 & 82,68 & 74,02 & 4,75 & 0,176 & 99,95 \\
2 & 0,57 & 15,46 & 87,84 & 78,64 & 4,47 & 0,166 & 99,95 \\
3 & 0,54 & 14,53 & 82,57 & 73,92 & 4,76 & 0,176 & 99,95 \\
4 & 0,54 & 14,47 & 82,23 & 73,62 & 4,78 & 0,177 & 99,95 \\
5 & 0,51 & 13,69 & 77,83 & 69,68 & 5,05 & 0,187 & 99,95 \\
6 & 0,54 & 14,68 & 83,40 & 74,67 & 4,71 & 0,174 & 99,95 \\
7 & 0,57 & 15,32 & 87,08 & 77,96 & 4,51 & 0,167 & 99,95 \\
8 & 0,55 & 14,90 & 84,69 & 75,82 & 4,64 & 0,172 & 99,95 \\
9 & 0,54 & 14,61 & 83,02 & 74,33 & 4,73 & 0,175 & 99,95 \\
10 & 0,52 & 13,95 & 79,27 & 70,97 & 4,96 & 0,184 & 99,95 \\
\hline
\end{tabular}

Tabela 4. Área enleirada, massa de palhiço enleirado, capacidade efetiva e operacional e balanço energético no tratamento duplo. $\mathrm{AE}=$ área enleirada; $\mathrm{MA}=$ massa estimada de palhiço enleirado; $\mathrm{CE}=$ capacidade efetiva; $\mathrm{CO}=$ capacidade operacional; $\mathrm{CA}=$ consumo de combustível por hectare; $\mathrm{CM}=$ consumo de combustível por tonelada; $\mathrm{BE}=$ balanço energético

\begin{tabular}{cccccccc}
\hline Repetições & $\begin{array}{c}\mathrm{AE} \\
(\mathrm{ha})\end{array}$ & $\begin{array}{c}\text { MA } \\
(\mathrm{t})\end{array}$ & $\begin{array}{c}\mathrm{CE} \\
\left(\mathrm{t} . \mathrm{h}^{-1}\right)\end{array}$ & $\begin{array}{c}\mathrm{CO} \\
\left(\mathrm{t} . \mathrm{h}^{-1}\right)\end{array}$ & $\begin{array}{c}\mathrm{CA} \\
\left(\mathrm{L} \cdot \mathrm{ha}^{-1}\right)\end{array}$ & $\begin{array}{c}\mathrm{CM} \\
\left(\mathrm{L} . \mathrm{f}^{-1}\right)\end{array}$ & $\begin{array}{c}\text { BE } \\
(\%)\end{array}$ \\
\hline 1 & 0,904 & 24,40 & 56,24 & 50,89 & 6,45 & 0,24 & 99,93 \\
2 & 0,915 & 24,72 & 56,98 & 51,56 & 6,37 & 0,24 & 99,93 \\
3 & 0,953 & 25,73 & 59,31 & 53,66 & 6,12 & 0,23 & 99,94 \\
4 & 0,968 & 26,13 & 60,23 & 54,49 & 6,02 & 0,22 & 99,94 \\
5 & 1,005 & 27,13 & 62,53 & 56,57 & 5,8 & 0,21 & 99,94 \\
6 & 1,021 & 27,58 & 63,57 & 57,51 & 5,71 & 0,21 & 99,94 \\
7 & 1,061 & 28,66 & 66,05 & 59,76 & 5,49 & 0,20 & 99,94 \\
8 & 1,055 & 28,49 & 65,67 & 59,41 & 5,53 & 0,20 & 99,94 \\
9 & 1,081 & 29,20 & 67,30 & 60,89 & 5,39 & 0,20 & 99,94 \\
10 & 1,104 & 29,82 & 68,72 & 62,18 & 5,28 & 0,20 & 99,95 \\
11 & 1,152 & 31,12 & 71,73 & 64,9 & 5,06 & 0,19 & 99,95 \\
12 & 1,160 & 31,32 & 72,18 & 65,31 & 5,03 & 0,19 & 99,95 \\
13 & 1,186 & 32,03 & 73,81 & 66,78 & 4,92 & 0,18 & 99,95 \\
14 & 1,185 & 32,00 & 73,75 & 66,73 & 4,92 & 0,18 & 99,95 \\
15 & 1,226 & 33,11 & 76,32 & 69,05 & 4,75 & 0,18 & 99,95 \\
\hline
\end{tabular}


Tabela 5. Volumes, densidades dos fardos e tempos no enfardamento cilíndrico simples. $\mathrm{VF}=$ volume do fardo; $\mathrm{DF}=$ densidade do fardo; $\mathrm{TE}=$ tempo de enfardamento; $\mathrm{AF}=$ área estimada na formação do fardo

\begin{tabular}{lcccc}
\hline Tratamentos & $\begin{array}{c}\mathrm{VF} \\
\left(\mathrm{m}^{3}\right)\end{array}$ & $\begin{array}{c}\mathrm{DF} \\
\left(\mathrm{kgf.m}^{-3}\right)\end{array}$ & $\begin{array}{c}\text { TE } \\
(\mathrm{s})\end{array}$ & $\begin{array}{c}\text { AF } \\
(\mathrm{ha})\end{array}$ \\
\hline CR1S & 2,57 & 165,63 & 133,60 & 0,04 \\
CR2S & 2,72 & 164,11 & 160,66 & 0,04 \\
CR3S & 2,72 & 166,98 & 210,41 & 0,06 \\
CR4S & 2,60 & 181,82 & 359,36 & 0,10 \\
\hline
\end{tabular}

Tabela 6. Velocidade no enfardamento cilíndrico, capacidade efetiva e massa estimada no tratamento cilíndrico simples. $\mathrm{VE}=$ velocidade de enfardamento; $\mathrm{CM}=$ capacidade efetiva em massa; $\mathrm{CA}=$ capacidade efetiva em área; $\mathrm{MP}=$ massa estimada de palhiço enfardado

\begin{tabular}{ccccc}
\hline Tratamentos & $\begin{array}{c}\mathrm{VE} \\
\left(\mathrm{Km} \cdot \mathrm{h}^{-1}\right)\end{array}$ & $\begin{array}{c}\mathrm{CM} \\
\left(\mathrm{t} . \mathrm{h}^{-1}\right)\end{array}$ & $\begin{array}{c}\mathrm{CA} \\
\left(\mathrm{ha} \cdot \mathrm{h}^{-1}\right)\end{array}$ & $\begin{array}{c}\mathrm{MP} \\
\left(\mathrm{t} . \mathrm{ha}^{-1}\right)\end{array}$ \\
\hline CR1S & 2,85 & 11,45 & 1,04 & 11,03 \\
CR2S & 2,67 & 10,02 & 0,97 & 10,29 \\
CR3S & 3,08 & 7,78 & 1,08 & 7,21 \\
CR4S & 2,86 & 4,73 & 1,03 & 4,58 \\
\hline
\end{tabular}

Tabela 7. Consumo de combustível e balanço energético no tratamento cilíndrico simples. $\mathrm{CF}=$ consumo de combustível por fardo; $\mathrm{CH}=$ consumo horário de combustível; $\mathrm{CT}=$ consumo de combustível por tonelada enfardada; $\mathrm{BE}=$ balanço energético do enfardamento; $\mathrm{BT}=$ balanço energético do enfardamento e enleiramento

\begin{tabular}{cccccc}
\hline Tratamentos & $\begin{array}{c}\text { CF } \\
\text { (L) }\end{array}$ & $\begin{array}{c}\text { CH } \\
\left(\mathrm{L.}^{-1}\right)\end{array}$ & $\begin{array}{c}\text { CT } \\
\left(\mathrm{L} . \mathrm{t}^{-1}\right)\end{array}$ & $\begin{array}{c}\text { BE } \\
(\%)\end{array}$ & $\begin{array}{c}\text { BT } \\
(\%)\end{array}$ \\
\hline CR1S & 0,392 & 10,55 & 0,60 & 99,83 & 99,78 \\
CR2S & 0,441 & 9,89 & 0,64 & 99,82 & 99,77 \\
CR3S & 0,669 & 11,44 & 0,65 & 99,82 & 99,77 \\
CR4S & 1,058 & 10,60 & 0,67 & 99,81 & 99,76 \\
\hline
\end{tabular}


Tabela 8. Índice de palhiço, umidade e terra total no tratamento cilíndrico simples. IPU = índice de palhiço da sub-amostra em base úmida; IPS = índice de palhiço da sub-amostra em base seca; $U$ = umidade do palhiço; ITS = índice de matéria estranha total; $\mathrm{ME}=$ massa de matéria estranha total

\begin{tabular}{lccccc}
\hline Tratamentos & $\begin{array}{c}\text { IPU } \\
(\%)\end{array}$ & $\begin{array}{c}\text { IPS } \\
(\%)\end{array}$ & $\begin{array}{c}\text { U } \\
(\%)\end{array}$ & $\begin{array}{c}\text { IM } \\
(\%)\end{array}$ & $\begin{array}{c}\text { ME } \\
\left(10^{-3} \cdot \mathrm{kg}\right)\end{array}$ \\
\hline CR1S1 & 92,08 & 80,60 & 12,46 & 2,23 & 65,46 \\
CR1S2 & 92,08 & 80,32 & 13,95 & 3,09 & 39,50 \\
CR2S1 & 92,08 & 67,52 & 19,23 & 2,52 & 49,83 \\
CR2S2 & 92,08 & 69,92 & 16,05 & 2,73 & 53,99 \\
CR3S1 & 92,08 & 82,14 & 12,38 & 2,11 & 32,07 \\
CR3S2 & 94,35 & 84,71 & 10,25 & 2,34 & 37,63 \\
CR4S1 & 93,95 & 81,75 & 13,00 & 4,56 & 85,09 \\
CR4S2 & 95,70 & 55,07 & 42,45 & 5,24 & 97,54 \\
\hline
\end{tabular}

Tabela 9. Terra no fardo no tratamento cilíndrico simples. $\mathrm{MF}=$ massa do fardo; $\mathrm{MA}=$ massa da amostra; MBS = massa de terra (bateria de peneiras); $\mathrm{TC}=$ porcentagem de terra e cinzas; $\mathrm{TF}=$ terra aderida a folha; $\mathrm{CL}=$ cinzas de palhiço lavado; $\mathrm{TA}=$ terra na amostra; $\mathrm{MT}=$ massa de terra no fardo; $\mathrm{MT}=$ porcentagem de terra no fardo

\begin{tabular}{ccccccccccc}
\hline Tratamentos & $\begin{array}{c}\text { MF } \\
(\mathrm{kg})\end{array}$ & $\begin{array}{c}\text { MA } \\
(\mathrm{kg})\end{array}$ & $\begin{array}{c}\text { MBS } \\
(\mathrm{kg})\end{array}$ & $\begin{array}{c}\text { TC } \\
(\%)\end{array}$ & $\begin{array}{c}\text { TF } \\
(\%)\end{array}$ & $\begin{array}{c}\text { CL } \\
(\%)\end{array}$ & $\begin{array}{c}\text { TA } \\
(\%)\end{array}$ & $\begin{array}{c}\text { TA } \\
(\mathrm{kg})\end{array}$ & $\begin{array}{c}\text { MT } \\
(\mathrm{kg})\end{array}$ & $\begin{array}{c}\text { PT } \\
(\%)\end{array}$ \\
\hline CR1S1 & 425 & 2,94 & 0,20 & 86,38 & 2,23 & 0,97 & 88,60 & 0,18 & 38,55 & 9,07 \\
CR1S2 & 425 & 1,28 & 0,07 & 86,38 & 3,09 & 0,96 & 89,46 & 0,07 & 37,56 & 8,84 \\
CR2S1 & 447 & 1,98 & 0,26 & 89,84 & 2,52 & 0,96 & 92,36 & 0,24 & 77,11 & 17,25 \\
CR2S2 & 447 & 1,98 & 0,28 & 89,84 & 2,73 & 0,96 & 92,57 & 0,26 & 79,33 & 17,75 \\
CR3S1 & 455 & 1,52 & 0,08 & 78,49 & 2,11 & 0,96 & 80,59 & 0,07 & 31,90 & 7,01 \\
CR3S2 & 455 & 1,61 & 0,08 & 78,49 & 2,34 & 0,95 & 80,82 & 0,07 & 30,68 & 6,75 \\
CR4S1 & 472 & 1,87 & 0,10 & 77,92 & 4,56 & 0,96 & 82,48 & 0,08 & 43,73 & 9,26 \\
CR4S2 & 472 & 1,86 & 0,05 & 77,92 & 5,24 & 0,96 & 83,16 & 0,04 & 40,62 & 8,60 \\
\hline
\end{tabular}

Tabela 10. Volumes, densidades dos fardos e tempos no enfardamento cilíndrico duplo. $\mathrm{VF}=$ volume do fardo; $\mathrm{DF}=$ densidade do fardo; $\mathrm{TE}=$ tempo de enfardamento; $\mathrm{AF}$ = área estimada na formação do fardo

\begin{tabular}{ccccc}
\hline Tratamentos & $\begin{array}{c}\text { VF } \\
\left(\mathrm{m}^{3}\right)\end{array}$ & $\begin{array}{c}\mathrm{DF} \\
\left(\mathrm{kgf.m^{-3 }}\right)\end{array}$ & $\begin{array}{c}\text { TE } \\
(\mathrm{s})\end{array}$ & $\begin{array}{c}\text { AF } \\
(\mathrm{ha})\end{array}$ \\
\hline CR1D & 2,35 & 200,75 & 119,41 & 0,04 \\
CR2D & 2,39 & 190,63 & 114,66 & 0,03 \\
CR3D & 2,58 & 171,08 & 126,95 & 0,04 \\
CR5D & 2,08 & 203,99 & 142,07 & 0,04 \\
\hline
\end{tabular}


Tabela 11. Velocidade no enfardamento cilíndrico, capacidade efetiva e consumo de combustível no tratamento duplo. $\mathrm{VE}=$ velocidade de enfardamento; $\mathrm{CM}=$ capacidade efetiva em massa; $\mathrm{CA}=$ capacidade efetiva em área; $\mathrm{MP}=$ massa estimada de palhiço enfardado

\begin{tabular}{ccccc}
\hline Tratamentos & $\begin{array}{c}\mathrm{VE} \\
\left(\mathrm{Km} \cdot \mathrm{h}^{-1}\right)\end{array}$ & $\begin{array}{c}\mathrm{CM} \\
\left(\mathrm{t} . \mathrm{h}^{-1}\right)\end{array}$ & $\begin{array}{c}\mathrm{CA} \\
\left(\mathrm{ha}^{-1}\right)\end{array}$ & $\begin{array}{c}\text { MP } \\
\left(\mathrm{t} . \mathrm{ha}^{-1}\right)\end{array}$ \\
\hline CR1D & 2,14 & 14,24 & 1,26 & 11,33 \\
CR2D & 1,82 & 14,32 & 1,07 & 13,42 \\
CR3D & 2,08 & 12,49 & 1,22 & 10,24 \\
CR5D & 2,37 & 10,73 & 1,10 & 9,76 \\
\hline
\end{tabular}

Tabela 12. Consumo de combustível e balanço energético no tratamento cilíndrico duplo. $\mathrm{CF}=$ consumo de combustível por fardo; $\mathrm{CH}=$ consumo horário de combustível; $\mathrm{CT}=$ consumo de combustivel por tonelada enfardada; $\mathrm{BE}=$ balanço energético do enfardamento; $\mathrm{BT}=$ balanço energético do enfardamento e enleiramento

\begin{tabular}{cccccc}
\hline Tratamentos & $\begin{array}{c}\text { CF } \\
(\mathrm{L})\end{array}$ & $\begin{array}{c}\mathrm{CH} \\
\left(\mathrm{L} \cdot \mathrm{h}^{-1}\right)\end{array}$ & $\begin{array}{c}\mathrm{CT} \\
\left(\mathrm{L} \cdot \mathrm{t}^{-1}\right)\end{array}$ & $\begin{array}{c}\text { BE } \\
(\%)\end{array}$ & $\begin{array}{c}\text { BT } \\
(\%)\end{array}$ \\
\hline CR1D & 0,41 & 12,28 & 0,45 & 99,96 & 99,903 \\
CR2D & 0,33 & 10,43 & 0,44 & 99,96 & 99,904 \\
CR3D & 0,42 & 11,93 & 0,42 & 99,96 & 99,905 \\
CR5D & 0,54 & 13,58 & 0,41 & 99,96 & 99,907 \\
\hline
\end{tabular}

Tabela 13. Índice de palhiço, umidade e terra total no tratamento cilíndrico duplo. IPU = índice de palhiço da sub-amostra em base úmida; IPS = índice de palhiço da sub-amostra em base seca; $U$ = umidade do palhiço; ITS = índice de matéria estranha total; $\mathrm{ME}=$ massa de matéria estranha total

\begin{tabular}{cccccc}
\hline Tratamentos & $\begin{array}{c}\text { IPU } \\
(\%)\end{array}$ & $\begin{array}{c}\text { IPS } \\
(\%)\end{array}$ & $\begin{array}{c}\text { U } \\
(\%)\end{array}$ & $\begin{array}{c}\text { IM } \\
(\%)\end{array}$ & $\begin{array}{c}\text { ME } \\
\left(10^{-3} \cdot \mathrm{kg}\right)\end{array}$ \\
\hline CR1D1 & 95,49 & 85,26 & 10,72 & 1,26 & 16,72 \\
CR1D2 & 95,19 & 79,57 & 16,42 & 2,80 & 21,31 \\
CR2D1 & 93,71 & 79,29 & 15,39 & 3,62 & 91,64 \\
CR2D2 & 92,76 & 76,78 & 17,22 & 2,20 & 54,45 \\
CR3D1 & 94,88 & 76,42 & 19,46 & 3,87 & 40,08 \\
CR3D2 & 92,20 & 76,25 & 17,30 & 0,85 & 22,71 \\
CR5D1 & 94,49 & 81,66 & 13,59 & 1,84 & 15,37 \\
CR5D2 & 88,83 & 74,54 & 16,08 & 4,07 & 117,47 \\
\hline
\end{tabular}


Tabela 14. Terra no fardo no tratamento cilíndrico duplo. MF = massa do fardo; MA = massa da amostra; $\mathrm{MBS}=$ massa de terra (bateria de peneiras); $\mathrm{TC}=$ porcentagem de terra e cinzas; $\mathrm{TF}=$ terra aderida a folha; $\mathrm{CL}=$ cinzas de palhiço lavado; $\mathrm{TA}=$ terra na amostra; $\mathrm{MT}=$ massa de terra no fardo; $\mathrm{MT}=$ porcentagem de terra no fardo

\begin{tabular}{ccccccccccc}
\hline Tratamentos & $\begin{array}{c}\text { MF } \\
(\mathrm{kg})\end{array}$ & $\begin{array}{c}\text { MA } \\
(\mathrm{kg})\end{array}$ & $\begin{array}{c}\text { MBS } \\
(\mathrm{kg})\end{array}$ & $\begin{array}{c}\text { TC } \\
(\%)\end{array}$ & $\begin{array}{c}\text { TF } \\
(\%)\end{array}$ & $\begin{array}{c}\text { CL } \\
(\%)\end{array}$ & $\begin{array}{c}\text { TA } \\
(\%)\end{array}$ & $\begin{array}{c}\text { TA } \\
(\mathrm{kg})\end{array}$ & $\begin{array}{c}\text { MT } \\
(\mathrm{kg})\end{array}$ & $\begin{array}{c}\text { PT } \\
(\%)\end{array}$ \\
\hline CR1D1 & 472,3 & 1,33 & 0,06 & 85,49 & 1,26 & 0,95 & 86,75 & 0,05 & 24,15 & 5,11 \\
CR1D2 & 472,3 & 0,76 & 0,04 & 85,49 & 2,80 & 0,96 & 88,29 & 0,03 & 32,66 & 6,91 \\
CR2D1 & 456,1 & 2,53 & 0,16 & 79,39 & 3,62 & 0,96 & 83,01 & 0,13 & 39,29 & 8,61 \\
CR2D2 & 456,1 & 2,47 & 0,18 & 79,39 & 2,20 & 0,96 & 81,59 & 0,15 & 36,27 & 7,95 \\
CR3D1 & 440,6 & 1,04 & 0,05 & 83,20 & 3,87 & 0,96 & 87,07 & 0,05 & 35,83 & 8,13 \\
CR3D2 & 440,6 & 2,67 & 0,21 & 83,20 & 0,85 & 0,95 & 84,05 & 0,17 & 32,35 & 7,34 \\
CR5D1 & 423,4 & 0,83 & 0,05 & 87,52 & 1,84 & 0,96 & 89,37 & 0,04 & 28,21 & 6,66 \\
CR5D2 & 423,4 & 2,89 & 0,32 & 87,52 & 4,07 & 0,97 & 91,59 & 0,30 & 58,62 & 13,84 \\
\hline
\end{tabular}

